\title{
ESSAYS ON THE DUTCH DISEASE
}

\author{
by
}

\section{Nazanin Behzadan}

Master of Arts - Economics, York University, Canada, 2010
Bachelor of Arts - Economics, Alzahra University, Iran, 2008

A dissertation

presented to Ryerson University

in partial fulfillment of the

requirements for the degree of

Doctor of Philosophy

in the program of

Economics

Toronto, Ontario, Canada, 2019

(c) Nazanin Behzadan, 2019 


\section{AUTHOR'S DECLARATION}

I hereby declare that I am the sole author of this dissertation. This is a true copy of the dissertation, including any required final revisions, as accepted by my examiners.

I authorize Ryerson University to lend this dissertation to other institutions or individuals for the purpose of scholarly research.

I further authorize Ryerson University to reproduce this dissertation by photocopying or by other means, in total or in part, at the request of other institutions or individuals for the purpose of scholarly research.

I understand that my dissertation may be made electronically available to the public. 
Essays on the Dutch Disease

Nazanin Behzadan

Doctor of Philosophy 2019

Department of Economics

Ryerson University

\begin{abstract}
In this dissertation I analyze the effect of within-country income inequality on economic outcomes. I develop a new model of international trade with non-homothetic preferences whereby within-country income distribution affects the pattern of trade and economic growth. An appreciation of the real exchange rate inducing a production shift to the sector with less long-run growth potential is known as the Dutch disease and in this model the disease is triggered by within-country income differences.

First, I show that the Dutch disease can arise solely from inequality in the distribution of natural resource rents where the country with the less equal distribution will have less production of manufacturing goods and less development of learning-by-doing in this sector. As opposed to conventional models, where income distribution has no effect on economic outcomes, an unequal distribution of the resource wealth can generate the Dutch disease. In addition, alternative forms of foreign transfers, such as foreign aid and remittances, interact with the income distribution in dissimilar manners and generate differences in spending patterns, the real exchange rate, production patterns, and the pattern of international trade. I show that while foreign aid can cause economic stagnation, remittances can in fact foster economic growth.

I also provide a range of empirical tests of the theoretical model, including both difference and system GMM estimations in a dynamic panel setting and disentangle the effects of inequality and institutional quality. My empirical analyses support the hypothesis that inequality indeed plays a significant role in whether being resource-rich is a blessing or a
\end{abstract}


curse for a country. The more unequal is the distribution of natural resource rents, the stronger is the disease. Moreover, I verify my hypothesis that foreign aid and remittances are not similar in generating the Dutch disease using data from a panel of countries and industries covering the years 1991-2009 while controlling for the issues of omitted variable bias and the endogeneity of the transfers. Finally, a similar method is used in order to draw empirical evidence that lends credence to the positive relation between more equal distribution of resource rents and higher manufacturing growth. 


\section{CO-AUTHORSHIP STATEMENT}

This thesis contains Chapter 2 co-authored with Richard Chisik. Together we worked on the conception of the theoretical model and its resolution. 


\section{ACKNOWLEDGEMENT}

I would like to extend my gratitude to everyone who supported and encouraged me during my PhD studies.

I would like to specially express my sincere gratitude to my supervisor Dr. Richard Chisik for his continuous professional support and guidance throughout my PhD studies. Dr. Chisik's constructive advice and persistent feedback has always encouraged me during my research work and prepared me for my future goals. Without his help and support this dissertation would not be possible.

My sincere thanks also goes to the members of my advisory committee; Dr. German Pupato, Dr. Min Seong Kim, and Dr. Haomiao Yu who dedicated their valuable time and provided me with continuous insightful comments and suggestions throughout my PhD studies. Also, I am grateful to the Department of Economics at Ryerson University, Dr. Maurice Roche and Dr. Claustre Bajona, as the chairs of the department during my PhD studies, for providing me and my classmates with support and the possible means to enjoying a dynamic and productive research environment.

Finally, my warmest thanks goes to my family and friends for their love and understanding. My special thanks to my parents who have inspired me in every chapter of my life and taught me to truly believe in myself; and my brothers for continuously encouraging and supporting me. 


\section{DEDICATION}

To my parents. Without their love and support this would never be possible. 


\section{Contents}

$\begin{array}{lll}\text { Abstract } & \text { iii }\end{array}$

List of Tables $\quad$ x

List of Figures $\quad$ xii

1 Introduction $\quad 1$

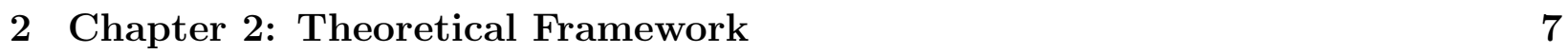

2.1 Introduction . . . . . . . . . . . . . . . . . . . . . 7

2.2 The Economic Environment . . . . . . . . . . . . . . . . . 10

2.3 Natural Resource Rents . . . . . . . . . . . . . . . . . . . . . . . . 14

2.3.1 International Trade . . . . . . . . . . . . . . . 16

2.3.2 Resource Rent Distribution and the Dutch Disease . . . . . . . . . . 18

2.4 Foreign Transfers . . . . . . . . . . . . . . . . . . . . 24

2.4 .1 International Trade . . . . . . . . . . . . . . . . . . . . . 27

2.4.2 Aid Versus Remittances . . . . . . . . . . . . . . . . . 28

2.5 Natural Resource Rent Distribution and Manufacturing Firms . . . . . . . . 34

2.5.1 International Trade . . . . . . . . . . . . . . . . . . . 34

2.5.2 Resource Rent Distribution and Market Share . . . . . . . . . . . . . 39

2.6 Conclusion . . . . . . . . . . . . . . . . . . . . . . 42

3 Chapter 3: Does Inequality Drive the Dutch Disease? Empirical Evidence. 44

3.1 Introduction . . . . . . . . . . . . . . . . . . . . . 44

3.2 Dynamic Panel Analysis . . . . . . . . . . . . . . . . . . . 49

3.2.1 Difference GMM estimation . . . . . . . . . . . . . . 51

3.2.2 System GMM estimation . . . . . . . . . . . . . . 56

3.2.3 Additional Robustness Checks . . . . . . . . . . . . . . . . . 59

3.3 Cross-Sectional Analysis . . . . . . . . . . . . . . . . . . . . . . 68 


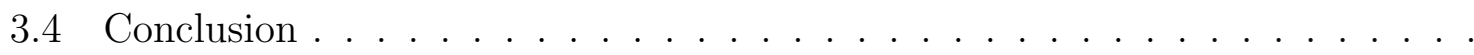

4 Chapter 4: From Paradox of Transfers to Resource Rent Distribution: $\begin{array}{ll}\text { Empirical Evidence on the Dutch Disease. } & 78\end{array}$

4.1 Introduction . . . . . . . . . . . . . . . . . . . . . 78

4.2 Paradox of Transfers . . . . . . . . . . . . . . . . . . . 81

4.2 .1 Fixed Effects Estimation . . . . . . . . . . . . . . . . . 83

4.2 .2 Instrumental Variable Estimation . . . . . . . . . . . . . . . 88

4.3 Natural Resource Rents . . . . . . . . . . . . . . . . . . . . . . . . . 93

4.3 .1 Fixed Effects Estimation . . . . . . . . . . . . . . . . . . . 94

4.4 Conclusion . . . . . . . . . . . . . . . . . . . . . . . . . . . 98

$\begin{array}{ll}\text { Bibliography } & 100\end{array}$ 


\section{List of Tables}

1 Definitions and Sources of the Variables . . . . . . . . . . . . . . . . . 47

2 Summary Statistics . . . . . . . . . . . . . . . . . . 48

3 List of the Countries . . . . . . . . . . . . . . . . . . . . . . . 49

4 Unitroot Test . . . . . . . . . . . . . . . . . . . . . 50

5 Test of Autocorrelation in the Error Terms . . . . . . . . . . . . . . . . 52

6 Arellano-Bond Estimation . . . . . . . . . . . . . . . . . 53

7 Correlation Matrix . . . . . . . . . . . . . . . . . . . 54

8 Arellano-Bond Estimation; Robustness Check Using Residuals . . . . . . . . 55

9 Blundell-Bond Estimation . . . . . . . . . . . . . . . . . 57

10 Blundell-Bond Estimation; Robustness Check Using Residuals . . . . . . . . 58

11 Arellano-Bond Estimation (Two Lags) . . . . . . . . . . . . . . . . . . 60

12 Arellano-Bond Estimation; Robustness Check Using Residuals (Two Lags) . 61

13 Blundell-Bond Estimation (Two lags) . . . . . . . . . . . . . . . . . . 62

14 Blundell-Bond Estimation; Robustness Check Using Residuals (Two lags) . . 63

15 Arellano-Bond Estimation (Three lags) . . . . . . . . . . . . . . . . 64

16 Arellano-Bond Estimation; Robustness Check Using Residuals (Three lags) . 65

17 Blundell-Bond Estimation (Three lags) . . . . . . . . . . . . . . 66

18 Blundell-Bond Estimation; Robustness Check Using Residuals (Three lags) . 67

19 Definitions and Sources of the Variables; Cross Sectional Analysis . . . . . . 70

20 Cross Sectional Analysis . . . . . . . . . . . . . . . . . . . . 72

21 Cross Sectional Causal Inference . . . . . . . . . . . . . . . . . . 75

22 Cross Sectional Causal Inference Robustness Check . . . . . . . . . . . . . 76

23 List of Countries . . . . . . . . . . . . . . . . . . . . . . . . 82

24 Description of ISIC Industry Divisions and Measures of Exportability . . . . 84

25 Summary Statistics $(1991-2009) \ldots \ldots$. . . . . . . . . . 85

26 Fixed Effects Estimation . . . . . . . . . . . . . . . 86

27 IV First Stage Estimation . . . . . . . . . . . . . . . . . . . . . . 91 
28 Weak Identification Test . . . . . . . . . . . . . . . . . . . . . . . . 92

29 IV Second Stage Estimation _ . . . . . . . . . . . . . . . . . . 93

30 Summary Statistics; Natural Resource Rents and the Gini Coefficient (1991-

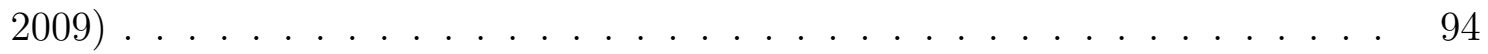

31 Fixed Effects Estimation; Natural Resource Rents . . . . . . . . . . . . . . . 94

32 Fixed Effects Estimation; Natural Resource Rents and the Distribution . . . 95

33 Fixed Effects Estimation; Natural Resource Rents and the Distribution (The Restricted Sample $\ldots \ldots \ldots$. . . . . . . . . . . . . . . 97 


\section{List of Figures}

1 Demand and Resource Rents Distribution . . . . . . . . . . . . . . 16

2 Distribution and the Pattern of Trade . . . . . . . . . . . . . . 20

3 Effect of a Transfer on Demand . . . . . . . . . . . . . . . . . . . . 26

4 Official Development Assistance vs. Remittances . . . . . . . . . . . . . 79 


\section{Introduction}

The Dutch disease is an old, well-known, and still relevant paradox in economics. It describes how the initial good fortune of an exhaustible natural resource find, a foreign transfer, or a commodity price boom can turn sour in the long run. The original use of the term "Dutch disease" (in the Economist magazine, 1977) referred to an appreciation of the Dutch guilder after oil was found in the North Sea. This currency appreciation rendered Dutch manufactured goods uncompetitive in world markets and generated a long-run export illness. In this dissertation it is shown that this phenomenon can arise solely because of the unequal distribution of various types of windfalls among the recipients. In fact, understanding the sources of economic inequality has long been an important topic of research for economists and political philosophers and it is also a subject of considerable contemporary interest. ${ }^{1}$ In this dissertation, however, the opposite direction is analyzed and it is asked how withincountry income inequality can affect economic outcomes.

In particular, with natural resource rents, it is demonstrated that a mean-preserving increase in the inequality of the rent distribution can generate manufacturing sector stagnation and lower long-run growth, even in a country with a smaller resource base and (initially) higher manufacturing productivity than its trading partners. Moreover, when it comes to foreign transfers, it is considered how different types of transfers alter patterns of consumption, production, and international trade. Consequently, a new paradox is identified: The effect of the transfer depends on the eventual recipient's pre-transfer income as well as their position within their country's income distribution.

My results build on and contribute to a large literature. Recognizing the limitation of a purely nominal exchange-rate explanation of the Dutch disease, several economists have developed models that provide additional non-monetary explanations of this malady. Starting with Corden and Neary (1982) economists have recognized a factor of production movement effect

\footnotetext{
${ }^{1}$ Important books on this topic span Rousseau's (1984) Age of Enlightenment treatise through Piketty's (2003) work. The "Sources of Inequality" is currently (in 2018) one of the thirteen themes of research at the National Bureau of Economic Research.
} 
and a spending effect as elements of the Dutch disease. ${ }^{2}$ Krugman (1987), Matsuyama (1992), Torvik (2001) and Goderis and Malone (2011) all introduce learning-by-doing and dynamic effects into models of the Dutch disease. ${ }^{3}$

An interesting difference between the model in this dissertation and the above mentioned papers (as well as Neary (1988), van der Ploeg and Venables (2013), and Beine, Coulombe and Vermeulen (2015)) is that the wage in the country that has the resource boom (or less equal distribution) does not increase relative to that of the other country even under full employment. In fact, it can even decline over time without changing my results. This is possible because there is two way trade in the manufacturing sector and all manufacturing goods have the same initial labor productivity. Therefore, unlike traditional Dutch disease models, manufacturing production does not need to be more costly in the resource abundant country. It is simply not a priority in the short run.

Although this study is the first to consider the effect of the distribution of natural resource rents as generating the Dutch disease, the question of distribution comes up in other papers. Goderis and Malone (2011) also consider the relationship between natural resources and income distribution. Their concern, however, is with the effect of the resource find and the resulting reallocation of skilled and unskilled labor (along with changes in learning-by-doing) on the level of inequality between skilled and unskilled workers. In Corden's (1984) survey, he suggests (in footnote 5) that changes in factor prices in a Heckscher-Ohlin framework could actually overturn the spending effect found in Corden and Neary (1982). His suggestion is very different from my result which shows how the spending effect can be magnified (and not overturned) if the distribution of the resource rents is less equal.

My emphasis on the importance of resource rent distribution in creating Dutch disease effects resonates with the resource curse literature which conditions the curse on poor political

\footnotetext{
${ }^{2}$ The basic premise of production factors shifting to the sector with increased productivity follows from standard textbook models of comparative advantage (Ricardo, Ricardo-Viner, and the Rybczynski effect) and by itself, without a consequent loss of learning-by-doing or external economies of scale, would not generate lower long-run growth.

${ }^{3}$ Matsuyama (1992) not only provides an explanation of the Dutch disease, but, more importantly, shows how an increase in agricultural productivity can generate long-run growth in a closed but not an open economy.
} 
governance (see, for example, the literature cited in van der Ploeg (2011) and Acemoglu and Robinson (2012)). Although my framework emphasizes the Dutch disease aspects (a production shift that eventually generates manufacturing stagnation) of natural resource abundance, it develops a bridge to the natural resource curse literature (that emphasizes the consequent decline in institutions) by emphasizing the role of resource rents distribution. ${ }^{4}$ As much as institutional quality is related to income and natural resource rent distribution, then my model suggests that the effect may exist at a more primitive distributional level. I also provide a new explanation for the observation that point-source natural resource finds (such as diamonds, gold, or oil) are more likely to reduce long-run growth than are dispersed-source resource finds (such as timber, fisheries, or many non-precious metals). The prevailing school of thought (see the literature cited in van der Ploeg (2011) and Acemoglu and Robinson (2012)) from the resource curse literature suggests that point-source resources are more valuable for expropriation, and therefore, generate unstable, kleptocratic societies plagued by bad institutions. The model here, on the other hand, implies that because diffuse source resources are naturally distributed in a diffuse manner they do not engender the same spending effects as do point-source (and point-distributed) resources. In this way the natural resource curse and Dutch disease explanations are tied together. ${ }^{5}$

My analysis also relates to a recent debate evolving around the optimal use of resource revenues in developing countries (Collier, van der Ploeg, Spence, and Venables, 2010). Although I do not consider alternative distribution mechanisms to this effect, my main result demonstrates that equality in the distribution of natural resource rents could be an important factor to cope with Dutch disease dynamics. Future contributions to this discussion should explicitly consider the mechanisms through which natural resource rents are allocated. ${ }^{6}$

\footnotetext{
${ }^{4}$ It may be said that whereas the Dutch disease is primarily an international economics phenomenon, the resource curse does not require an international or interregional economics framework. Neary (1988) succinctly summarizes the Dutch disease as an appreciation of the real exchange rate of non-traded for traded goods which is generated by the change in an exogenous variable that pushes up the demand for traded versus non-traded goods. Although his observation is stated for an economically small country the same result holds in large economy Dutch disease models such as the one in this paper.

${ }^{5}$ In addition to the Dutch disease and resource curse theories as to the negative effect of natural resources on growth there is a crowding-out of education effect as demonstrated by Gylfason (2001).

${ }^{6} \mathrm{An}$ important observation here is that different allocation mechanisms may not be perfect substitutes. For example, remittances or foreign aid are conventionally considered to be analogous to natural resource
} 
As mentioned earlier, foreign transfers - mainly taking the form of development aid or remittances - are another type of windfalls that can result in the Dutch disease. The adverse effects of international transfers was first considered when Keynes (1929) and Ohlin (1929) debated the possible results of German war reparations. The theoretical literature on the transfer paradox was initiated by Leontief (1936) and extended by Samuelson (1952), Balasko (1978), Chichilnisky (1983), Geanakoplos and Heal (1983), and Galor and Polemarchakis (1987). More recently, Corden and Neary (1982), van Wijnbergen $(1985,1986)$, and Krugman (1987) have shown that a foreign transfer may generate an appreciation of the real exchange rate which can cause specialization in the sector with less long-run growth potential (a Dutch disease) in the recipient country. ${ }^{7}$ There is also a large literature (referenced in footnotes 8 and 9) on the effects of ODA and an excellent overview is provided by Rajan and Subramanian (2008). I add to these literatures by showing that the effect of the transfer depends on the income of the recipient and in this way also draw important distinctions between differing types of transfers. ${ }^{8}$ Moreover, this dissertation adds to the Dutch disease literature by showing that the presence of the disease depends on the distribution of the windfall.

Whereas there are large differences between countries on their net receipts of aid and remittances I am especially interested in the differential effect of aid and remittances within the same country. Foreign aid is usually given to a government and then transferred to the desired recipient of that aid. There is an extensive literature that suggests that many of finds in the literature. Although all these channels denote a windfall, the channels of injection to the economy could be different. Whereas the natural resource rents may be captured by the upper segments of the income distribution, remittances may be associated with poor or middle-class households on the receiver ends. My framework, therefore, shows that natural resource finds and remittances may have different Dutch disease implications.

${ }^{7}$ Corden and Neary (1982) were the first to provide a non-monetary explanation of this disease. I consider the Dutch disease to be an international trade phenomenon, whereby an appreciation of real exchange rate causes the "sick" country to become an importer of goods with better long-run growth potential. It differs from a closed economy phenomenon such as the Rybczynski effect or the resource curse (which would correspond to ODA being misused to support corrupt dictators) in that the windfall requires a trading environment to transform itself into a disease.

${ }^{8}$ In their handbook chapter on migration Foster and Rosenzweig (2008) also consider remittances and show that migration along with emigrant remittances can facilitate structural change in rural labour markets. Dinkelman, Kumchulesi, and Mariotti (2017) also provide empirical evidence that remittances can foster structural change in rural labour markets. 
these aid payments are fungible and have little effect on the desired group. ${ }^{9}$ There is an almost equally large literature that suggests that foreign aid is worse than fungible and is, in fact, used to prop up corrupt governments and their supporters. ${ }^{10}$ Whether aid is fungible and partially serves to reduce the taxes paid by the wealthy, or is used to support cronyism and corruption, aid benefits a wealthier segment of the population that would not normally receive remittances.

Remittances, on the other hand, do not pass through a government middleman and are more likely to end up in the hands of the poorer inhabitants of a country. Dinkelman, Kumchulesi, and Mariotti (2017) show that remittances from Malawi nationals working as gold miners in South Africa allowed their poor agrarian families to accumulate capital and move out of the agricultural sector. Furthermore, as shown by Faini (2007) and Niimi, Ozden and Schiff (2010) skilled migrants - who are more likely to come from middle class families - remit less. It is true that remittances are also sent to middle class recipients and that some aid to governments does eventually find its way to the intended poorer recipient. My key assumption is simply that the distribution of remittances, by the recipients wealth, lies to the left (in the sense of first order stochastic dominance) of the distribution of aid.

It is this difference in the expected recipients of aid and remittances that is the starting point for my analysis. If the marginal propensity to consume out of a foreign transfer depends on the individual's initial level of income, then foreign transfers that are given to different segments of the population could generate very different outcomes. Hence, studying the average consumer may tell us little about the spending pattern of individual consumers. This observation is especially relevant in developing countries or those where a larger percent of the population lives below the poverty level.

Furthurmore, the role of income on growth through its effect on demand is stressed by Herrendorf, Rogerson, and Valentinyi (2014) who show that poor countries consume and

\footnotetext{
${ }^{9}$ See, for example, Azam and Laffont (2003), Chatterjee, Giuliano and Kaya (2007), Depetris and Raay (2005), Devarajan, Rajkumar and Swaroop (2007), Gang and Khan (1991), Khilji and Zampelli (1994), McGillivray and Morrissey (2000, 2001), Pack and Pack (1990, 1993), Swaroop, Jha and Rajkumar (2000).

${ }^{10}$ See, for example, Alesina and Weder (2002), Bauer (2000), Coyne and Ryan (2009), Djankov, Montalvo and Reynal-Querol (2006), Easterly (2001, 2006), Younas (2008).
} 
produce more manufactured goods and that services only become important as a country becomes more wealthy. Diao, McMillan, and Rodrik (2017) also consider non-homothetic preferences in a model of growth and argue that the differing patterns of structural change across Africa and Asia were in part determined by their original income level and consequent consumption patterns. My research complements the above by suggesting that structural change, growth, and convergence may be determined not only by the average level of income across countries but also by the distribution of income within a country. Recent work that introduces non-homothetic preferences into a model of international trade with crosscountry differences includes Matsuyama (2000), Fieler (2011), Fajgelbaum, Grossman and Helpman (2011), Markusen (2013), Caron, Fally and Markusen (2014), and Simonovska (2015). Fajgelbaum and Khandelwal (2016) and Behzadan, Chisik, Onder, and Battaile (2017) also consider within-country income differences. I add to this literature by analyzing the effect of foreign aid and remittances in an international trade model with non-homothetic preferences and within-country income inequality.

The following outlines the structure of the remaining of this dissertation: In chapter 2, the theoretical model is provided. Chapter 3, presents the empirical evidence on if the Dutch disease is driven by inequality of the resource rent distribution. Finally, in chapter 4, I introduce new empirical methodology and evidence on relating the paradox of transfers, resource rents, and the Dutch disease. 


\section{Chapter 2: Theoretical Framework}

\section{$2.1 \quad$ Introduction}

In this chapter I develop a simple theoretical model that can capture the effect of windfalls on the economy. First, I provide the basics of a benchmark model and then I analyze how natural resource rents and foreign transfers affect economic growth. Finally, in order to study how firms within the manufacturing sector are affected by a windfall, I relax the assumption of perfect competition in this sector and analyze the effects on the market share.

In this framework the Dutch disease stems from a shift in demand, without a production movement or increased wage effect. With a new-found wealth from the resource discovery, the demand for non-tradable luxury consumption services increases. Consequently, labor that could be used to develop the manufacturing sector is pulled into the service sector and manufactured goods become more likely to be imported. Although the economy may develop increased expertise in the service sector, most of these luxury services are targeted at domestic consumption and not easily exportable. Moreover, because manufacturing is more prone to learning and production process improvements, the potential gains in productivity accrue to foreign exporters. As a result, once the resource is diminished, there is less income to purchase the services and, thus, the resource find can generate economic stagnation.

The key to model in this chapter is an increase in the share of income spent on luxury services that accompanies the windfall wealth. ${ }^{11}$ The marginal (and average) propensities to consume are commonly assumed to be independent of income in the literature. These constant income share assumptions, which rely on homothetic preferences, however, have two limitations. First, they are repeatedly contradicted by empirical evidence. Second, aggregate demand is not affected by income distribution under the assumption of homothetic preferences. As the distribution of the windfall wealth is often unequal, it is necessary to consider how changes in the distribution of this wealth affects the prevalence of the Dutch disease. Thus, in this framework, I consider not only per capita income but also changes in

\footnotetext{
${ }^{11}$ I use the term luxury to indicate an income elasticity greater than one.
} 
the distribution of income.

On the other hand, different types of international transfers find their way to different segments of the population (a literature review is provided in chapter 4). For this assumed difference in the recipients of aid and remittances to affect economic outcomes a framework that captures the following ideas is adopted. First, consumption patterns change with income. In particular, the marginal propensity to consume services is increasing in income. Second, services are less tradable than manufactured goods. ${ }^{12}$ Poor people often do not purchase these services in the market and, therefore, have a lower income elasticity of demand for these services than do wealthier people. ${ }^{13}$ Third, increased production of manufactured goods generates more production externalities than do services.

As a result, The most important element of this model is the representation of non-homothetic preferences which permits a meaningful analysis of within country differences in the marginal propensity to consume out of a foreign transfer. It has been common in economic models to assume that the marginal (and average) propensity to consume a good is (are) not dependent on income. These constant income shares, that result from the assumption of homothetic preferences, are frequently employed in the economics literature. Although they have several nice mathematical properties they are repeatedly contradicted by the empirical evidence. From Stone's (1954) seminal work on expenditures and Deaton and Muellbauer's (1980) classic study of consumer behaviour through Hunter and Markusen's (1988) groundbreaking work that demonstrates its importance in explaining the pattern of trade, the data continually confirm that preferences are non-homothetic and that consumption bundles do change with income.

Putting these ideas together I show that the Dutch disease is more likely to arise when the resource rent distribution is less equal. This is intuitive since a natural resource find

\footnotetext{
${ }^{12}$ These luxury services pertain to services whose demand increases with income. Examples of these nontradable services are housekeeping, childcare, lawn care, nannies, butlers, chauffeurs, private security forces, the staff to service a large estate, or the financial expertise necessary for laundering misdirected foreign aid payment.

${ }^{13}$ An implied result of this framework is that poorer people are more trade dependent than are the wealthy. Put another way, internationally traded goods make up a larger portion of the consumption bundle of poorer people. This result is substantiated empirically in a recent paper by Fajgelbaum and Khandelwal (2016).
} 
is like finding money. By itself, it should not generate lower long-run welfare unless it creates expenditure distortions. If the resource wealth is narrowly distributed, then, as will be shown below, the distortions are greater. In particular, as a result of the assumed non-homotheticity of preferences, wealthier agents have a greater marginal propensity to consume services. It is then shown that a mean preserving spread of the natural resource rent distribution shifts more income to the wealthier agents and generates an increase in the total purchase of services. Crucially in this case, the increase in the purchases of services is of larger magnitude than the decrease in the purchase of manufactured goods, so that the country with a less equal distribution becomes a net importer of manufactured goods. As a result, given two countries with identical technologies, labor supplies, skill development, and natural resources, but differences in income distribution (solely as a result of ownership of the rents generated by the resources), the country with the less equal distribution will have less production of manufacturing goods and less development of learning-by-doing in this sector.

Furthermore, I incorporate non-homothetic preferences in an otherwise traditional international trade model with production, three sectors, and endogenously determined prices, and show that a foreign transfer which is given to wealthier rather than to poorer people increases the relative demand for services and (through a consequent increase in the real exchange rate) reduces manufacturing production, thereby generating an increased reliance on imported manufactured goods and a consequent reduction in the growth of manufacturing. Finally, the following results are established; First, it is shown that foreign aid generates a reduction in manufacturing output. Second, remittances generate an increase in manufacturing output. Third, the difference between the effect of aid and remittances on manufacturing sector growth is positive. Fourth, these effects are dynamic, so that a one time payment can generate increased future effects. Fifth, the positive effect of remittances (and the negative effect of foreign aid) is more pronounced in countries that have a more equal pre-transfer distribution of income.

In the next section the economic environment of each country is described. In Section 2.3 I 
consider the effect of natural resource rents followed by the effects of international transfers in section 2.4. Finally, in section $2.5 \mathrm{I}$ analyze how the manufacturing firms are affected by a windfall distribution.

\subsection{The Economic Environment}

Following Corden and Neary's (1982) seminal work, I consider two tradable sectors in each country - manufacturing goods and a numeraire sector - and a non-tradable luxury consumption services sector. The manufacturing goods include manufacturing services as well as sales and infrastructure services for the manufactured goods. Items in the services sector are non-tradable and include items such as construction, entertainment, household services (from childcare to chauffeurs). Manufacturing and services are both produced with a constant returns to scale technology using labour, the only factor of production. There is learning-by-doing in the manufacturing sector so more production in the current period boosts labour productivity in later periods. The numeraire sector can be interpreted as the natural resource sector that generates rents for the wealthy consumers or depending on the application, the numeraire sector can also be thought of as agriculture that provides the wealthy people with a per period rental income from their agricultural land endowment. ${ }^{14}$ In this simple model, the numeraire is either consumed domestically or exported. Thus, the numeraire good is not produced with labour but rather realized as an endowment, which then allows us to demonstrate the Dutch disease without a resource movement effect. The price of the numeraire good is set on world markets and is normalized to unity.

The numeraire endowment in each country is given as $\theta_{t}\left(\theta_{t}^{*}\right)$. In the foreign country each agent is endowed with the same amount of the numeraire good. The measure of home country agents who are endowed with the numeraire is $\kappa$, where $0<\kappa \leq 1$. I will refer to the $\kappa$ agents as rich and to the $1-\kappa$ as poor. ${ }^{15}$ Each of the rich agents owns $\theta_{t}^{R}$ units of oil and

\footnotetext{
${ }^{14} \mathrm{An}$ alternative interpretation for the numeraire is a financial asset that pays $\theta / \kappa\left(\theta^{*}\right)$ to each of the wealthy in the home (foreign) regions. Continuing with this line of thought the transfer could consist of money. A potential problem with this interpretation is that the numeraire enters the utility function. Furthermore, there is no additional benefit of introducing money into the model. I, therefore, prefer to adhere to the agricultural interpretation.

${ }^{15}$ Note that I consider my measure of distribution as time invariant. I make this assumption for several
} 
$\kappa \theta_{t}^{R}=\theta_{t}$. Hence, if $\kappa<1$, then each of the rich agents owns more than the average so that $\theta_{t}^{R}>\theta_{t}$. The measure of rich agents indexes the natural resource (and income) distribution in the home country. Note that a reduction in $\kappa$ generates a mean-preserving spread in the natural resource rent distribution. Hence, inequality is decreasing in $\kappa$ and the distribution is equal when $\kappa$ approaches one. I will, therefore, refer to decreases (increases) in $\kappa$ as a worsening (improvement) of the natural resource rent distribution.

Each of the individuals in the home and foreign region are endowed with one unit of labour which is supplied inelastically in the domestic market and I normalize the labour supply in each region to unity. Individuals supply their labour to either the manufacturing or services sector. Unrestricted labour mobility between these two sectors ensures that all labour earns the same wage of $w_{t}\left(w_{t}^{*}\right)$ in the home (foreign) region. In addition to their wage individuals may earn income from the numeraire sector. This numeraire income may come from an endowment of $\theta_{t}\left(\theta_{t}^{*}\right)$ that is divided among the $\kappa\left(\kappa^{*}\right)$ wealthy individuals in the home (foreign) regions or from a transfer payment, $\tau_{t}$, that is given to the home region. As I am only interested in the effect of the transfer on the home region it is assumed that income is equally distributed in foreign, therefore, $\kappa^{*}=1$ so that all foreign inhabitants share equally in the endowment and are wealthy.

The technology for producing manufactured goods and services is of Ricardian type and the manufacturing production follows a learning-by-doing process. Formally, one unit of labor produces $M_{t},\left(M_{t}^{*}\right)$ units of the manufacturing good in the home (foreign) country. The labour productivity in manufacturing is a function of the entire past output. In particular, the labour productivity at time $t$ increases with past output as a result of the learning and refinement of the production process in previous periods. The output of manufactured goods in the home country at time $t$ can be represented as

reasons. First, resource rent distribution policy usually does not change much over time unless it is accompanied by a complete change of government (or a revolution) and even in that case the change is typically a substitution of one connected group of recipients for another. Second, although point and diffuse source resources suggest different patterns of distribution, a country rarely, if ever, changes from being, say, predominantly exporting oil to mostly exporting timber. Third, my data set exhibit negligible intertemporal variation in inequality regardless of the chosen measure. 


$$
Q_{M t}=\ell_{M t} M_{t}=\ell_{M t} \int_{0}^{t} \delta Q_{M \tau} d \tau
$$

where $\delta<1$ and $\ell_{M t}$ is the quantity of labour supplied to the manufacturing sector in period $t$. Foreign learning obeys the same process with the same $\delta$, however, there are no international learning spillovers. Of course, $\ell_{M t}^{*}$ and $Q_{M t}^{*}$ may differ. From this point on I will not separately describe the foreign variables when the distinction is obvious. The instantaneous rate of change in labor productivity in the manufacturing sector is $\dot{M}_{\tau}=\delta Q_{M \tau}$. At times I will be interested in describing the labor productivity at time 0 before any learning has occurred $\left(M_{0}\right)$.

The technology for producing services is the same in both countries and is given by $\ell_{S t}=\frac{q_{S t}}{A}$ $\left(\ell_{S t}^{*}=\frac{q_{S t}^{*}}{A}\right)$ where $A=A^{*}$ are the identical labour productivities in the services sectors in both countries. Finally, the numeraire good is provided as an endowment and is not produced.

Individuals in each country use their per-period income to purchase manufactured goods, services, and a numeraire good. Their consumption of good $j$ in period $t$ is $d_{j t}$ and their preferences over consumption from these three sectors can be represented by the following utility function:

$$
U=\int_{0}^{\infty} e^{-\rho t} u\left(d_{S t}, d_{M t}, d_{O t}\right) d t=\int_{0}^{\infty} e^{-\rho t}\left(d_{S t}+\gamma\right)^{\alpha}\left(d_{M t}\right)^{\beta}\left(d_{O t}\right)^{1-\alpha-\beta} d t
$$

where $\rho>0$ is the common rate of time preference.

The per-period utility function is of the Stone-Geary variety. If $\gamma=0$, then these preferences would be Cobb-Douglass and agents would spend a constant income share $(\alpha, \beta, 1-\alpha-\beta)$ on each of the goods. As will be seen below, with $\gamma>0$ services become a luxury good so that the marginal propensity to consume services is increasing in income. Stone-Geary preferences are more commonly depicted with $\gamma<0$ so that it determines a subsistence level of the good. The more common depiction does not allow for a consideration of withincountry income distribution because all agents must achieve the subsistence level of the 
good and, therefore, all have the same marginal propensity to consume out of income. My luxury good version, with $\gamma>0$, allows some agents to purchase no services in the market and allows us to make meaningful statements about within-country income distribution. ${ }^{16}$ The services sector may consist of household services, transportation services, childcare or elder care, education, socializing with friends or family, playing sports, reading, or taking walks. The parameter, $\gamma>0$, can be interpreted as the amount of services that can be consumed without being purchased in the market. For example, an individual could prepare their own meals, care for their own children and drive their own car, or they could employ a chef, a nanny and a chauffeur. Certain services that are consumed only by the very wealthy, such as private security forces, the staff to service a large estate, or the financial expertise necessary for laundering misdirected foreign aid payments are more likely to be purchased. ${ }^{17}$ In this model, $\gamma>0$ is the amount of services that can be enjoyed without being purchased in the market. ${ }^{18}$

There is no uncertainty and no possibility for international or intertemporal borrowing and lending. Hence, maximization of the above utility function subject to the per period income constraint $P_{S t} d_{S t}+P_{M t} d_{M t}+d_{O t}=I_{t}$, where $P_{j}$ is the price of good $j$ and $I$ is income, yields the following demand functions.

$$
\begin{gathered}
d_{S}=\operatorname{Max}\left\{0, \frac{\alpha I-P_{S} \gamma(1-\alpha)}{P_{S}}\right\} \\
d_{M}=\operatorname{Min}\left\{\frac{\beta I}{(1-\alpha) P_{M}}, \frac{\beta\left(I+P_{S} \gamma\right)}{P_{M}}\right\}
\end{gathered}
$$

\footnotetext{
${ }^{16}$ Although empirical work, such as Stone (1954), the extensive literature cited in Deaton and Muellbauer (1980), and Hunter and Markusen (1988), among others has repeatedly shown that preferences are not homothetic, it is still not obvious what is the best functional form for representing non-homothetic preferences. The Stone-Geary function that is chosen here (but with a subsistence requirement so that $\gamma<0$ ) is the most commonly employed.

${ }^{17}$ Consumption in the manufacturing, services, and numeraire sectors could all be considered as coming from a constant-elasticity-of-substitution aggregator where the elasticity of substitution is infinite. Hence, $d_{j}=\sum d_{z j}$ for all of the different goods or services (indexed by $z$ ) in sector $j$.

${ }^{18}$ Markusen (2013) makes use of a similar utility function with two goods and also shows that increased income inequality can increase demand for the luxury good. He uses this result to provide an explanation for the home bias effect in trade.
} 


$$
d_{O}=\operatorname{Min}\left\{\frac{I(1-\alpha-\beta)}{(1-\alpha)},\left(I+P_{S} \gamma\right)(1-\alpha-\beta)\right\}
$$

The foreign country demand functions are similar. From this point forward I will omit the time subscript and the foreign country derivations when not necessary for the exposition. In what follows, I present two sections that each relate to a type of windfalls - either resource rents or international transfers - and their effect on the income of the recipient and, ultimately, economic growth.

\subsection{Natural Resource Rents}

In this section I consider the numeraie as a natural resource endowment, such as oil, which provides its owners with rents. Then the income, $I$, consists of wages and the numeraire endowment. When oil is equally distributed, I can treat the individual demand functions as the aggregate demand with income $I^{E}=w+\theta$. When it is not equally distributed, income for the rich agents is $I^{R}=w+\frac{\theta}{\kappa}$ and for the poor agents is $I^{P}=w$. In the foreign country, where the oil endowment is equally distributed, $I^{E *}=w^{*}+\theta^{*}$. In order to consider the

effects of income distribution, it is assumed that only rich people can purchase services. As a result, it is important to note that the piecewise-connected demand functions in equation (3) all switch from the first to the second component when

$$
I=\frac{P_{S} \gamma(1-\alpha)}{\alpha}=I^{0}
$$

For $I>I^{0}$ the purchase of services is positive. If labour productivity of services is relatively high, then their price, $P_{S}$ is relatively low and all individuals would purchases services and each individual would consume on the second term in their demand correspondences given above. My key assumption is, therefore,

\section{Assumption 1.}

$$
A<\frac{\gamma(1-\alpha)}{\alpha}<A+\frac{\theta}{\theta+\theta^{*}} \frac{(1-\alpha-\beta) g(\kappa)}{(\alpha+\beta)(1-\alpha)}
$$


where $g(\kappa)=A(1-\alpha \kappa)+\gamma(1-\alpha) \kappa$. As will be seen below, after the equilibrium goods and factor prices are derived (in equations (6) and (10)), assumption 1 is sufficient for

$$
w<\frac{P_{S} \gamma(1-\alpha)}{\alpha}=I^{0}<w+\theta
$$

so that when oil income is equally distributed there is positive demand for services by all agents (see equation (3)). There are two parts to assumption 1; ${ }^{19}$ The first inequality states that without oil income an agent will not purchase services in the market. It clearly requires non-homotheticity of preferences $(\gamma>0)$ and it is more likely to be satisfied if services are more of a luxury good (larger $\gamma$ ), if they comprise a smaller share of total expenditure (smaller $\alpha$ ) or if labor productivity in services (A) is not too large. The second inequality will be satisfied if the oil endowment $(\theta)$ is sufficiently large.

Inspection of the demand functions in equation (3) also reveals that rich and poor home country agents consume differing amounts of manufactured goods and oil. Although less people purchase services when income is not equally distributed, those who purchase them purchase relatively more of them (as a result of the positive income effect given by the non-homotheticity of preferences). An important determinant of my results is that the larger purchases dominates the fewer purchasers so that total purchases of services are larger when income is less equally distributed. In figure 1 depicts the demand for services and manufactured goods as a function of income.

The per-period utility function given in equation (2) allows the demand for services (manufactured goods) to be a strictly convex (concave) function of income. As seen in figure 1 a worsening of the resource rent distribution generates a mean preserving spread so that the quantity demanded of services (the convex function) increases and the quantity demanded of manufactured goods decreases. It will be seen below that these differences play an important part in explaining the pattern of trade and learning-by-doing in otherwise similar economies.

\footnotetext{
${ }^{19}$ Equation (5) is equivalent to $A<\frac{\gamma(1-\alpha)}{\alpha}<A+\frac{\theta}{\theta+\theta^{*}} \frac{(1-\alpha-\beta)\left[g(\kappa) M_{0}+(A+\gamma)(1-\alpha) M_{0}^{*}\right]}{(\alpha+\beta)(1-\alpha) M_{0}}$. Hence, the first inequality in assumption 1 is identical to the first inequality in equation (5). Evaluating the second inequality when $M^{*}=0$ yields the sufficient condition given in the second inequality in assumption 1.
} 


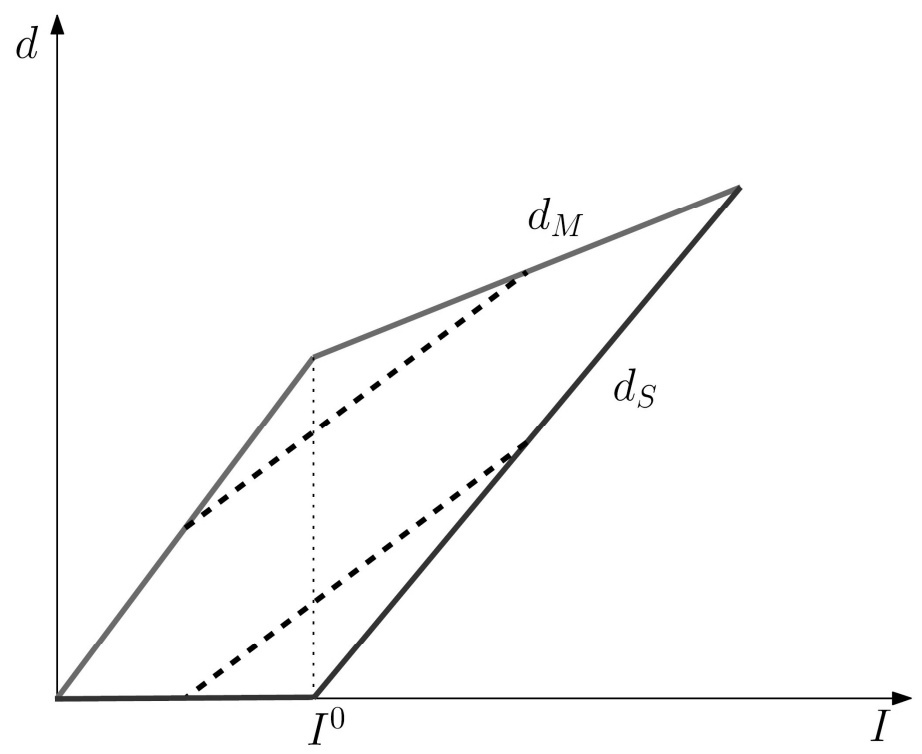

Figure 1: Demand and Resource Rents Distribution

\subsubsection{International Trade}

We now consider international trade between the home and foreign countries. The price of the non-traded services can differ across countries, but the price of the freely-traded manufactured goods and oil are equalized across countries in the free trade equilibrium. Given the above described technologies, we then have the following four equilibrium prices

$$
P_{M}=\frac{w}{M}=\frac{w^{*}}{M^{*}}, P_{S}=\frac{w}{A}, P_{S}^{*}=\frac{w^{*}}{A}, P_{O}=1
$$

Oil can be traded, but is not produced, therefore, the total world demand must equal the total world endowment. The demand for the non-traded services must equal its supply in each country. The labour, services, and (by Walras' law) the goods markets equilibrium is given by these equilibrium conditions.

$$
d_{O}+d_{O}^{*}=\theta+\theta^{*}, d_{S}=A\left(1-\ell_{M}\right), d_{M}^{*}=A\left(1-\ell_{M}^{*}\right)
$$

From the equality of world demand and supply for oil and the pricing equation for services 
we have

$$
\left[w(1-\kappa)+(1-\alpha) w \kappa+(1-\alpha) w^{*}+(1-\alpha) \frac{w \kappa+w^{*}}{A} \gamma\right][1-\alpha-\beta]=(1-\alpha)(\alpha+\beta)\left(\theta+\theta^{*}\right) .
$$

which uses the observations that $\kappa<1$ of the home agents have income $w+\frac{\theta}{\kappa}$ and the remaining $1-\kappa$ have income $w$.

Combining the separate zero excess demand conditions for services in each country along with the pricing equation for services yields the following two wage equations for home and foreign.

$$
w=\frac{A \alpha \theta}{A\left(1-\ell_{M}-\alpha \kappa\right)+\gamma(1-\alpha) \kappa}, w^{*}=\frac{A \alpha \theta^{*}}{A\left(1-\ell_{M}^{*}-\alpha\right)+\gamma(1-\alpha)} .
$$

Combining equations (8) and (9) along with the pricing equation for manufactured goods given in equation (6) completely describes the international trading equilibrium. The price of the manufacturing good, the measure of labor in the manufacturing sector in each country and the equilibrium home and foreign wage are then given by

$$
\begin{gathered}
P_{M}=\frac{A(\alpha+\beta)\left(\theta+\theta^{*}\right)(1-\alpha)}{\left[\left(M \kappa+M^{*}\right)(A+\gamma)(1-\alpha)+M A(1-\kappa)\right][1-\alpha-\beta]}, \\
\ell_{M}=\frac{\left[\theta \beta+(\alpha+\beta)(1-\alpha) \theta^{*}\right] g(\kappa) M-\alpha(1-\alpha-\beta) \theta g(1) M^{*}}{A M(\alpha+\beta)(1-\alpha)\left(\theta+\theta^{*}\right)}, \\
\ell_{M}^{*}=\frac{\left[\theta^{*} \beta+(\alpha+\beta)(1-\alpha) \theta\right] g(1) M^{*}-\alpha(1-\alpha-\beta) \theta^{*} g(\kappa) M}{A M^{*}(\alpha+\beta)(1-\alpha)\left(\theta+\theta^{*}\right)} \\
w=\frac{A M(\alpha+\beta)(1-\alpha)\left(\theta+\theta^{*}\right)}{(1-\alpha-\beta)\left[g(\kappa) M+g(1) M^{*}\right]}, \quad w^{*}=\frac{A M^{*}(\alpha+\beta)(1-\alpha)\left(\theta+\theta^{*}\right)}{(1-\alpha-\beta)\left[g(\kappa) M+g(1) M^{*}\right]}
\end{gathered}
$$

where $g(1)=(A+\gamma)(1-\alpha)$, which is $g(\kappa)$ evaluated at $\kappa=1$. Note that these equilibrium conditions are derived for the case where the distribution of the home oil rents are unequal. 


\subsubsection{Resource Rent Distribution and the Dutch Disease}

In this section I analyze how the home country's resource rent distribution affects the pattern of trade and the possibility of suffering a Dutch disease. From equation (10) we can see how the distribution of the resource rents affects the pattern of comparative advantage. In particular, we can characterize the ratio of the home to foreign labor share in manufacturing. If we then evaluate it when manufacturing productivity and resource endowments are the same, so that $M=M^{*}$ and $\theta=\theta^{*}$, then this ratio can be written as

$$
\frac{\ell}{\ell^{*}}=\frac{[2 \beta+\alpha(1-\alpha-\beta)] g(\kappa)-\alpha(1-\alpha-\beta) g(1)}{[2 \beta+\alpha(1-\alpha-\beta)] g(1)-\alpha(1-\alpha-\beta) g(\kappa)} .
$$

The ratio in equation (11) is equal to unity when $\kappa=1$. To evaluate this ratio when $\kappa<1$, note that the derivative of $g(\kappa)$ with respect to $\kappa$ is $\gamma(1-\alpha)-\alpha A$ which is positive by assumption $1 .{ }^{20}$ Hence, $g(\kappa)<g(1)$ for all $\kappa<1$, and the ratio in equation (11) is, therefore, less than one for all $\kappa<1$. Furthermore, as the home resource rent distribution becomes more unequal ( $\kappa$ decreases) the ratio becomes smaller and the home country falls further behind the foreign country in manufacturing production.

Equation (11) shows that the distribution of the resource rents can be a source of comparative advantage even when resource rents are equal. It provides a possible answer as to why some countries suffer a Dutch disease after finding a natural resource. Of course, equation (11) is a special case. To better see the effect of the natural resource distribution on manufacturing and service production we now consider the marginal effect of resource rents distribution after any history.

It is possible that after some histories, the manufacturing output in the country with unequal distribution of rents may be zero. As shown in proposition 1 if manufacturing output is positive in both countries, then worse home country distribution reduces home manufacturing output and increases that in foreign. The proposition also shows that the home country distribution (as well as manufacturing productivity and resource rents) determines whether

\footnotetext{
${ }^{20}$ The result that $g(\kappa)$ is increasing in $\kappa$ (which follows from assumption 1 ) is used throughout the remainder of the analysis.
} 
manufacturing output is greater than zero or not.

Proposition 1. There exists a $\hat{\kappa}\left(\theta, \theta^{*}, M_{t}, M_{t}^{*}\right)$ and a $\hat{\kappa}^{*}\left(\theta, \theta^{*}, M_{t}, M_{t}^{*}\right)$ such that home manufacturing output is positive only if $\kappa>\hat{\kappa}$ and foreign manufacturing is positive only if $\kappa<\hat{\kappa}^{*}$. If $\kappa \in\left(\hat{\kappa}, \hat{\kappa}^{*}\right)$, then an increase in the inequality of the home resource rent distribution reduces home manufacturing output and increases foreign output.

Proof. From equation (10) home manufacturing production is positive if

$$
\frac{M_{t}}{M_{t}^{*}}>\frac{\alpha(1-\alpha-\beta) \theta g(1)}{\left[\theta \beta+(\alpha+\beta)(1-\alpha) \theta^{*}\right] g(\kappa)} .
$$

Similarly foreign manufacturing is positive if

$$
\frac{M_{t}^{*}}{M_{t}}>\frac{\alpha(1-\alpha-\beta) \theta^{*} g(\kappa)}{\left[\theta^{*} \beta+(\alpha+\beta)(1-\alpha) \theta\right] g(1)} .
$$

The bounds given in equation (12) indicate that there exists a $\hat{\kappa}\left(\theta, \theta^{*}, M_{t}, M_{t}^{*}\right)$ such that home manufacturing is positive if and only if the equality of home resource rent distribution is above this critical level. Differentiation of both sides of equation (12) reveals that $\hat{\kappa}$ is increasing (decreasing) in the home (foreign) oil endowment and foreign (home) manufacturing productivity. Put succinctly, it is decreasing in $\theta^{*}$ and $M_{t}$ and increasing in $\theta$ and $M_{t}{ }^{*}$. Similarly, from equation (13) there exists a critical level of the home natural resource rent distribution $\hat{\kappa}^{*}\left(\theta, \theta^{*}, M_{t}, M_{t}^{*}\right)$ such that foreign manufacturing is positive if and only if $\kappa$ is below this critical level and $\hat{\kappa}^{*}$ is decreasing in $\theta^{*}$ and $M_{t}$ and increasing in $\theta$ and $M_{t}{ }^{*}$. Of course, unless the foreign oil endowment is much larger, or their manufacturing productivity is much lower, this critical $\hat{\kappa}^{*}$ would be greater than one and not relevant in equilibrium.

If the bounds in equations (12) and (13) are satisfied, then it is straightforward to verify the effect of the home country's resource rent distribution on manufacturing output in home and foreign. In particular, from equation (10) we have that

$$
\frac{\partial \ell_{M t}}{\partial \kappa}=\frac{\left[\theta \beta+(\alpha+\beta)(1-\alpha) \theta^{*}\right][\gamma(1-\alpha)-\alpha A]}{A(\alpha+\beta)(1-\alpha)\left(\theta+\theta^{*}\right)}>0
$$




$$
\frac{\partial \ell_{M t}^{*}}{\partial \kappa}=-\frac{\alpha(1-\alpha-\beta) \theta^{*}[\gamma(1-\alpha)-\alpha A] M_{t}}{A(\alpha+\beta)\left(\theta+\theta^{*}\right)(1-\alpha) M_{t}^{*}}<0 .
$$

In signing the above derivatives I again use assumption 1.

Proposition 1 extends the result in equation (11) by showing that a worsening in the distribution of the natural resource endowment not only changes the ratio of home to foreign manufacturing, but also causes an absolute reduction of manufacturing at home and an increase abroad. This result holds regardless of the previous history and of the manufacturing productivity in period $t$. In fact, the proof of this proposition shows that the reduction in home manufacturing is independent of the home manufacturing technology. On the other hand, greater relative home technology $\left(\frac{M}{M^{*}}\right)$ does reduce the foreign manufacturing growth that results from worse home resource rent distribution. Finally, note that the above result holds regardless of either country having a greater natural resource endowment. The results of proposition 1 are illustrated in figure 2 .

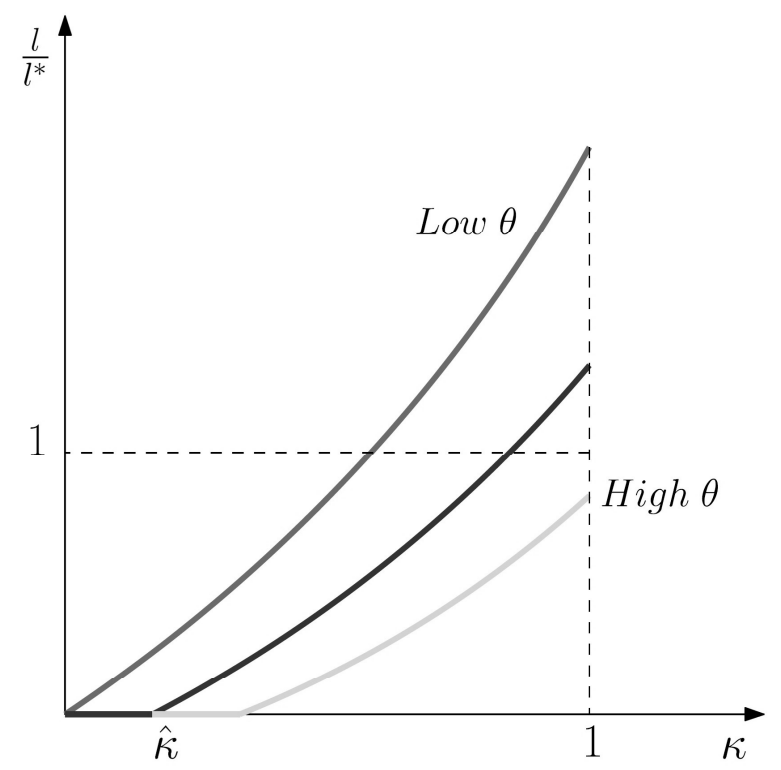

Figure 2: Distribution and the Pattern of Trade

In figure 2 we see that the relative level of home versus foreign manufacturing is a function not only of resource endowments and manufacturing productivity, but also the home country 
distribution of the resource rents. In particular, comparative advantage is also a function of the resource rent distribution. Even when the home country has better initial technology in manufacturing and a smaller natural resource endowment, it can still have a comparative disadvantage in manufacturing if it has worse natural resource rents distribution.

We now show that the Dutch disease can arise solely from less equal natural resource rents distribution. Furthermore, such an outcome is possible even in the absence of an increase in the relative wage of the country with worse resource rents distribution. In fact, as a result of the reduction in manufacturing output, the relative wage will decrease in the long run.

Proposition 2. A worsening of the home country resource rent distribution can generate manufacturing stagnation. It does so without a change in the relative home to foreign wage in the short run and with a decrease in the long run.

Proof. From equation (10) the relative home wage is $\frac{w_{t}}{w_{t}^{*}}=\frac{M_{t}}{M_{t}^{*}}$ which does not depend on the current period values of $\kappa, \theta$ or $\theta^{*}$. Hence, the relative wage does not change in the short run. After any change in the resource rent distribution of the home country, the total adjustment in the home manufacturing labor productivity at any time $t$ is given by

$$
d M_{t}=\int_{0}^{t} \delta \frac{\partial Q_{M \tau}}{\partial \ell_{M \tau}} \frac{\partial \ell_{M t}}{\partial \kappa} d \kappa d \tau=\int_{0}^{t} \delta M_{\tau} \frac{\partial \ell_{M t}}{\partial \kappa} d \kappa d \tau
$$

which, is strictly negative if $d \kappa<0$ and $\kappa>\hat{\kappa}$ and is weakly negative if $d \kappa<0$ and $\kappa \leq \hat{\kappa}$. Similarly, for $d \kappa<0$ and $\kappa<\hat{\kappa}^{*}$ the total change in foreign manufacturing labor productivity is

$$
d M_{t}^{*}=\int_{0}^{t} \delta \frac{\partial Q_{M \tau}^{*}}{\partial \ell_{M \tau}^{*}} \frac{\partial \ell_{M t}^{*}}{\partial \kappa} d \kappa d \tau=\int_{0}^{t} \delta M_{\tau}^{*} \frac{\partial \ell_{M t}^{*}}{\partial \kappa} d \kappa d \tau>0
$$

An interesting difference between this model and the models of the Dutch disease discussed in the introduction is that the wage in the country that has the resource boom (or the less equal income distribution) does not increase relative to that of the other country. In fact, 
it can decline over time. This result occurs mainly because international trade equalizes the domestic and foreign prices of manufactures, so that relative wages are given by Ricardian productivity differences across countries. In particular, there are constant returns to labour in the manufacturing sector in the model and all manufacturing goods have the same technology. In all but one of the previously mentioned Dutch disease models there are diminishing returns to labour so that as the wage rises, the labor demand adjusts, which in turn affects the marginal product of labor so that labor is still paid the value of its marginal product. In Krugman (1987) each of the manufacturing goods has a different labour productivity so that an increase in the relative wage corresponds to production of a set of goods with higher average labor productivity. In my model, on the other hand, each good in the manufacturing sector has the same Ricardian technology, therefore, no such adjustments are possible in the manufacturing sector and the relative wage does not rise in response to the change in the natural resource rents (or their distribution). Although it arises from a simplification designed so that I can more clearly present the main point about the distribution of the natural resource rents, this simple stylized model also shows that the Dutch disease can arise without an increase in the relative wage even when there is full employment.

If we were to consider two small countries (as in Corden and Neary (1984) or Matsuyama (1992)), then they would face a given price for the manufactured goods. In reassessing proposition 1 note that $P_{M}$ is decreasing in $\kappa$ so that a worsening of the home distribution raises the price of manufactured goods. This price increase somewhat attenuates the reduction in the home manufacturing sector but also generates an increase in the foreign manufacturing sector. In the case of two small economies there would be no change in $P_{M}$ and the reduction of the home manufacturing sector would be larger, but there would be no increase in the size of the foreign manufacturing sector. ${ }^{21}$ Given that many of the countries in my empirical sample could be considered as economically small it is important to see that my results are still valid for the case of a small country.

In my empirical analysis I make use of annual changes in the resource rents, therefore, it

\footnotetext{
${ }^{21}$ Treating $P_{M}$ as an exogenous parameter allows us to write $\ell_{M}=\frac{A(1-\alpha \kappa)+\gamma(1-\alpha) \kappa}{A}-\frac{\alpha \theta}{M P_{M}}$ and $\ell_{M}^{*}=$ $\frac{(1-\alpha)(A+\gamma)}{A}-\frac{\alpha \theta^{*}}{M^{*} P_{M}}$ so that $\frac{\partial \ell_{M t}}{\partial \kappa}=\frac{\gamma(1-\alpha)-\alpha A}{A}>0=\frac{\partial \ell_{M t}^{*}}{\partial \kappa}$.
} 
is necessary to show that my results are robust to temporary changes in resource rents or their distribution. My main concern is with the boom and bust cycle of a depletable natural resource find or the fluctuation in commodity prices. Furthermore, a temporary change in rent distribution can arise from a change in government policy. ${ }^{22}$ It may be wondered if, after the resource rents or their distribution return to their previous equal level, the now lower relative home wage (given by the loss of learning-by-doing) could offset the technology difference and shift manufacturing production back to its earlier level. I answer this question in proposition 3.

Proposition 3. If $M_{t}=M_{t}^{*}$, and from time $t$ to a finite time $\tau>t$ either $\theta>\theta^{*}$ or $\kappa<1$ or both, and after time $\tau, \theta=\theta^{*}$ and $\kappa=1$, then home will have lower manufacturing productivity, lower wages, and lower income for all time after $\tau$.

Proof. I begin by writing the ratio of home to foreign labour in manufacturing at time $t$ for the case when the resource rents and their distribution are equal in home and foreign.

$$
\frac{\ell_{M t}}{\ell_{M t}^{*}}=\frac{M_{t}^{*} M_{t}[2 \beta+\alpha(1-\alpha-\beta)]-M_{t}^{*} M_{t}^{*} \alpha(1-\alpha-\beta)}{M_{t}^{*} M_{t}[2 \beta+\alpha(1-\alpha-\beta)]-M_{t} M_{t} \alpha(1-\alpha-\beta)}
$$

Equation (16) shows that if $M_{t}<M_{t}^{*}$, then $\ell_{M t}<\ell_{M t}^{*}$ and foreign would have a comparative advantage in manufactured goods. Although $w_{t}<w_{t}^{*}$ (because $\frac{w_{t}^{*}}{w_{t}}=\frac{M_{t}^{*}}{M_{t}}$ ), this wage reduction will not be enough to offset the lower home manufacturing productivity. Wages cannot drop enough to reverse the pattern of trade given by comparative advantage. Furthermore, the reduction in the home wage will not change the measure of home agents that buy services, because the price of services is tied to the wage (see equations (5) and (6)). In equation (16) I only consider the case when manufacturing output is positive in home and foreign, however, the same result holds for the case when the home country does not produce manufactured goods. In particular, if the condition in equation (12) is not satisfied, then any further drop in the home relative wage would not bring back the manufacturing sector.

\footnotetext{
${ }^{22}$ As noted in footnote 2 , resource rent distribution is not expected to vary much over time, therefore, this second consideration is of less interest empirically.
} 
Hence, a temporary reduction in the equality of resource rent distribution or a temporary resource boom can generate permanent manufacturing stagnation. In addition, if home productivity drops enough so that $\hat{\kappa} \geq 1$, then home manufacturing could remain at zero even after the narrowly distributed resource boom is over.

\subsection{Foreign Transfers}

In this section I consider the effect of receiving transfers. In addition to their wage and income earned from the numeraire sector that is divided among the $\kappa\left(\kappa^{*}\right)$ wealthy, individuals also receive a transfer payment, $\tau_{t}$, that is given to the home region. As I am only interested in the effect of the transfer on the home region it is assumed that income is equally distributed in foreign, therefore, $\kappa^{*}=1$ so that all foreign inhabitants share equally in the endowment and are wealthy.

The idea here is that the transfer's effect depends on the pre-transfer income of the recipient. The variation in numeraire endowments captures these within country differences. I am interested in analyzing growth in the manufacturing and services sector and, therefore, the transfer should not consist of goods in these sectors. Hence, I keep the third sector in the model to capture both the transfer payments and the pre-transfer income distribution.

In addition to the endowment of the numeraire, the home region receives a foreign transfer, $\tau_{t}$, in terms of the numeraire good. In order to compare the differing effect of aid and remittances, or more generally, the effect of the income of the transfer recipient on the transfer outcome, I parameterize by $\eta$ as the portion of the transfer that is allocated to the $1-\kappa$ poorer individuals in the home region. The idea is that $\eta$ is larger for remittances. If remittances are given only to the poor, then $\eta=1$. If aid is given uniformly, then $\eta=1-\kappa \cdot{ }^{23}$ Income is generated by the wage paid to labour as well as the endowed numeraire, remittances, and foreign aid. Hence, per capita income is given as $I_{t}^{R}=w_{t}+\theta_{t} / \kappa+\tau_{t}(1-\eta) / \kappa$ for the $\kappa$ more affluent individuals in the home region and $I_{t}^{P}=w_{t}+\tau_{t} \eta /(1-\kappa)$ for the

\footnotetext{
${ }^{23}$ Aid is distributed to a government or regional authority who then disperses it according to their own preferences. Hence, it is likely that aid is not distributed uniformly. If the government distributes the aid narrowly to an entrenched elite, then $\eta$ would approach zero.
} 
$(1-\kappa)$ less affluent. Foreign per capita income is $I_{t}^{*}=w_{t}^{*}+\theta_{t}^{*}-(1-\nu) \tau_{t}$. The parameter $\nu$ measures the amount of the transfer that comes from the foreign country. If $\nu=1$, then the transfer is from other countries and is a pure windfall for the home country. On the other hand, if $\nu=0$, then there is a transfer of income from the foreign to the home country and this transfer will generate an additional effect on the relative wage. ${ }^{24}$

Using the equilibrium price for services $\left(P_{S}=\frac{w}{A}\right)$ from equation (6) below, I can re-write Assumption 1 given in equation (4) as a condition that guarantees that only the more affluent individuals in home and all individuals in foreign purchase services in the market.

$$
\begin{gathered}
A+\frac{A \tau \eta}{w(1-\kappa)}<\frac{\gamma(1-\alpha)}{\alpha}<A+\frac{A(\theta+\tau(1-\eta))}{w \kappa} \\
\frac{\gamma(1-\alpha)}{\alpha}<A+\frac{A\left(\theta^{*}-(1-\nu) \tau\right)}{w^{*}} .
\end{gathered}
$$

The above equations are functions of the yet to be determined wages which will be derived below (in equation (21)) and I will then discuss equation (17) in terms of the primitives (and the resulting condition will be called Assumption 3). Still, we can note several important aspects of my key assumption. From the first inequality in the first line of equation (17) we have that, in the absence of any transfer, $A<\frac{\gamma(1-\alpha)}{\alpha}$, which implies that productivity in services $(A)$ is not that large compared to the services that are self-provided $(\gamma)$. The second inequality in the first line and that in the second line require that the numeraire endowments are relatively large. Finally, the first inequality in the first line and that in the second line requires that the transfer $(\tau)$ is small in comparison to the numeraire endowment of either country $\left(\theta, \theta^{*}\right)$. To be precise we will require that $2 \tau<\theta^{*}$. This last inequality captures the

\footnotetext{
${ }^{24}$ To capture the effect of $\nu$ in my data, I created an H-index which is conceptually similar to the Herfindahl Index. My H-index is the product of two types of shares: the share of donor in the recipient's total aid, and the share of donor in the recipient's total trade value. A higher H-index implies that most of the aid is being donated by the major trading partners and is not a pure windfall from other countries. My H-index and $\nu$ have an inverse relation. In my dataset, which consists predominantly of developing country recipients, the $\mathrm{H}$-index is very small overall with a median of 0.074 . These very low values of my $\mathrm{H}$-index shows that aid is not coming from major trading partners. Hence, in my model, the parameter $\nu$ should be considered as close to unity. These overall low values of my $\mathrm{H}$-index, however, did render it impossible to capture any significant effects of the percentage of aid that comes from major trading partners.
} 
idea that the transfers are much smaller than the foreign endowment and it will be used as a sufficient condition (along with $A \alpha<\gamma(1-\alpha)$ ) in the proofs of several of the following propositions. I state these conditions here separately as Assumption 2.

\section{Assumption 2.}

$$
\begin{gathered}
\chi \alpha<\gamma(1-\alpha) \\
2 \tau<\theta^{*}
\end{gathered}
$$

From the demand functions in equation (3) and the the first line in equation (17) I can illustrate the main intuition behind this model in figure 3 which depicts the income expansion path for manufactured goods and for services.

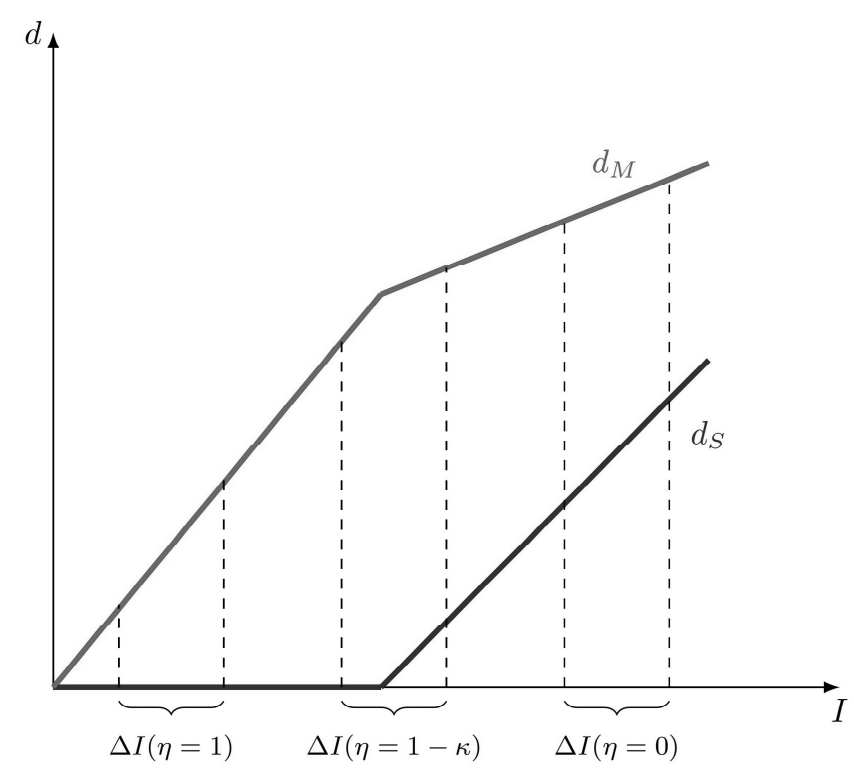

Figure 3: Effect of a Transfer on Demand

Crucially, these functions both change their slope at the critical income level $I^{0}$. A transfer in the form of a remittance (shown by $\Delta I(\eta=1)$ ) that is given to poorer people (those with income less than $I^{0}$ ) does not increase their spending on services after receiving the transfer, but does generate a steep increase in their purchase of manufactured goods. Aid that is given uniformly $(\Delta I(\eta=1-\kappa))$ does generate a modest increase in the demand for services and a less steep increase in the demand for manufactured goods. Finally, moving 
further to the right, we see the effect of aid that ends up in the hands of a narrow, already wealthy, group $(\Delta I(\eta=0)))$. In this case, aid generates the largest increase in the demand for services and the smallest increase in the demand for manufactured ones.

\subsubsection{International Trade}

As described in section 2.3.1 with international trade the freely traded manufactured goods and the numeraire have the same price in both regions, but the price of the non-traded services can differ across regions. Given the technologies, equilibrium prices are described as in equation (6).

The market clearing equilibrium conditions can be described as the following.

$$
d_{O}+d_{O}^{*}=\theta+\theta^{*}+\nu \tau, d_{S}=A \ell_{S}, d_{S}^{*}=A \ell_{S}^{*}
$$

From the services market prices given in equation (6) and the demand functions given in equation (3) we can rewrite the numeraire market clearing condition as the following:

$$
\begin{gathered}
\left(w[(1-\alpha \kappa) A+\gamma(1-\alpha) \kappa]+w^{*}[(1-\alpha)(A+\gamma)]\right)(1-\alpha-\beta)=\left(\theta+\theta^{*}+\tau \nu\right)(1-\alpha)(\alpha+\beta) \\
-\tau \eta \alpha(1-\alpha-\beta)
\end{gathered}
$$

where I have used the fact that the less affluent in the home region consume on the first part of the piece-wise connected demand function.

Combining the separate zero excess demand conditions for services in each region along with the pricing equation for services yields the following two wage equations for home and foreign.

$$
w=\frac{A \alpha[\theta+\tau(1-\eta)]}{\kappa[\gamma(1-\alpha)-A \alpha]+A \ell_{S}}, w^{*}=\frac{A \alpha\left[\theta^{*}-\tau(1-\nu)\right]}{\gamma(1-\alpha)+A\left(\ell_{S}-\alpha\right)} .
$$

Combining equations (20) and (19), the relationship between the price of manufactured 
goods, the wage from equation (6), and the relationship $\ell_{M}+\ell_{S}=1$, allows us to completely describe the international trading equilibrium. The measure of labour in the manufacturing sector in each country and the equilibrium home and foreign wage are then given as:

$$
\begin{gathered}
\ell_{M}=\frac{M g(\kappa)\left[\left(\theta+\theta^{*}\right) \Gamma_{\beta}+\tau\left(\nu \Gamma_{\beta}-\eta \Gamma_{\alpha}\right)\right]-\Gamma_{\alpha} \Gamma_{\kappa}[\theta+\tau(1-\eta)]}{A M\left[\left(\theta+\theta^{*}\right) \Gamma_{\beta}+\tau\left(\nu \Gamma_{\beta}-\eta \Gamma_{\alpha}\right)\right]} \\
\ell_{M}^{*}=\frac{M^{*} g(1)\left[\left(\theta+\theta^{*}\right) \Gamma_{\beta}+\tau\left(\nu \Gamma_{\beta}-\eta \Gamma_{\alpha}\right)\right]-\Gamma_{\alpha} \Gamma_{\kappa}\left[\theta^{*}-\tau(1-\nu)\right]}{A M^{*}\left[\left(\theta+\theta^{*}\right) \Gamma_{\beta}+\tau\left(\nu \Gamma_{\beta}-\eta \Gamma_{\alpha}\right)\right]} \\
P_{M}=\frac{w}{M}=\frac{w^{*}}{M^{*}}=\frac{A\left[\left(\theta+\theta^{*}\right) \Gamma_{\beta}+\tau\left(\nu \Gamma_{\beta}-\eta \Gamma_{\alpha}\right)\right]}{(1-\alpha-\beta) \Gamma_{\kappa}}
\end{gathered}
$$

where $g(\kappa)=A(1-\alpha \kappa)+\gamma(1-\alpha) \kappa, g(1)=(A+\gamma)(1-\alpha), \Gamma_{\alpha}=\alpha(1-\alpha-\beta), \Gamma_{\beta}=$ $(\alpha+\beta)(1-\alpha)$, and $\Gamma_{\kappa}=g(\kappa) M+g(1) M^{*}$.

Finally, using equation (21) the key assumption is written in equation (17) in terms of the primitives as assumption 3:

\section{Assumption 3.}

$$
\begin{gathered}
\chi+\frac{\tau \eta}{1-\kappa} \frac{(1-\alpha-\beta) \Gamma_{\kappa}}{\phi\left[\left(\theta+\theta^{*}\right) \Gamma_{\beta}+\tau\left(\nu \Gamma_{\beta}-\eta \Gamma_{\alpha}\right)\right]}<\frac{\gamma(1-\alpha)}{\alpha}< \\
\chi+\frac{\theta+\tau(1-\eta)}{\kappa} \frac{(1-\alpha-\beta) \Gamma_{\kappa}}{\phi\left[\left(\theta+\theta^{*}\right) \Gamma_{\beta}+\tau\left(\nu \Gamma_{\beta}-\eta \Gamma_{\alpha}\right)\right]}
\end{gathered}
$$

It is straightforward to verify that this assumption is satisfied if the amount of services that can be provided without being purchased in the market $(\gamma)$ is large, productivity in services $(A)$ or the intensity of their demand $(\alpha)$ is small, the per-capita transfer to poor people $\left(\frac{\tau \eta}{1-\kappa}\right)$ is small, and the endowments $\left(\theta, \theta^{*}\right)$ are large.

\subsubsection{Aid Versus Remittances}

In this section I derive the main theoretical predictions. The main variable of interest is the share of labour in the manufacturing sector $\left(\ell_{M}\right)$ and how it is affected by a transfer 
under different scenarios. If the transfer increases the output of the manufacturing sector, then through the dynamic effects of learning-by-doing it will generate an increase in long-run economic growth.

It is interesting to note that any effects that the transfer has on the manufacturing sector do not occur because of a change in the relative wage. In particular, note from equation (21) that the transfer has a similar effect on the wage in both countries (and the effect is equalized if both countries share the same technology so that $M=M^{*}$ ). If the transfer is from outside the two countries (so that $\nu=1$ ), then this effect is positive (because $\left.\Gamma_{\beta}=(\alpha+\beta)(1-\alpha)>\alpha(1-\alpha-\beta)=\Gamma_{\alpha}>\eta \alpha(1-\alpha-\beta)=\eta \Gamma_{\alpha}\right)$. If it is a transfer from foreign to home (so that $\nu=0$ ), then it is negative. The relative wage, however, is $\frac{w}{w^{*}}=\frac{M}{M^{*}}$, which is not a function of the transfer.

If both manufacturing and services outputs are positive, then the effect of the transfer on the manufacturing sector in the home country can be seen as follows.

$$
\frac{\partial \ell_{M}}{\partial \tau}=\frac{\Gamma_{\alpha} \Gamma_{\kappa}\left[\theta\left(\nu \Gamma_{\beta}-\eta \Gamma_{\alpha}\right)-(1-\eta)\left(\theta+\theta^{*}\right) \Gamma_{\beta}\right]}{A M\left[\left(\theta+\theta^{*}\right) \Gamma_{\beta}+\tau\left[\nu \Gamma_{\beta}-\eta \Gamma_{\alpha}\right]\right]^{2}} .
$$

The sign of the above derivative is determined by the sign of $\theta\left(\nu \Gamma_{\beta}-\eta \Gamma_{\alpha}\right)-(1-\eta)\left(\theta+\theta^{*}\right) \Gamma_{\beta}$. If the transfer is from foreign to home (so that $\nu=0$ ), then it is negative. Similarly if the transfer is only to the already wealthy ( so that $\eta=0$ ) then it must be negative even if $\nu=1$. On the other hand if the transfer is to the poorer inhabitants of the home country (so that $\eta=1$ ), then the transfer has a positive effect on the size of the manufacturing sector as long as the portion of the transfer that comes from outside the two countries is not too small. In particular, we require that $\nu>\frac{\Gamma_{\alpha}}{\Gamma_{\beta}}=\frac{\alpha(\mathbf{1}-\alpha-\beta)}{(\alpha+\beta)(\mathbf{1}-\alpha)}$. For example, if $\alpha=\beta=\frac{1}{3}$, then this requires that $\nu>\frac{1}{4} \cdot{ }^{25}$ We detail the marginal effects of the transfer on the home and foreign countries in proposition 4 .

Proposition 4. If the home and foreign regions both produce manufactured goods and services, then the marginal effect of the transfer on the size of the manufactured goods sector in the home country is:

\footnotetext{
${ }^{25}$ See footnote 11 , where we note that in a many country world $\nu$ approaches 1 for most countries.
} 
(i) increasing in the portion of the transfer distributed to poorer individuals.

(ii) increasing in the portion of the transfer that comes from outside of the foreign trading partner.

(iii) If the transfer is given only to the already wealthy, then it decreases the manufacturing sector.

(iv) If the transfer is given only to the poorer inhabitants, then it will increase the size of the manufacturing sector as long as the portion of the transfer that comes from outside of its trading relationship is greater than $1-\frac{\beta}{(\alpha+\beta)(\mathbf{1}-\alpha)}$ which is less than one.

(v) A transfer to the home country increases the size of the manufacturing sector in the foreign country.

Proof. (i) After some algebra we have that

$\frac{\partial^{2} \ell_{M}}{\partial \tau \partial \eta}=\frac{\Gamma_{\alpha} \Gamma_{\kappa}\left[\tau\left(\theta \Gamma_{\alpha}+\left(\theta+\theta^{*}\right) \Gamma_{\beta}\right)\left(\nu \Gamma_{\beta}-\eta \Gamma_{\alpha}\right)+\left(\theta+\theta^{*}\right) \Gamma_{\beta}\left(\left(\theta+\theta^{*}\right) \Gamma_{\beta}-[(1-\eta) 2 \tau+\theta] \Gamma_{\alpha}\right)\right]}{A M\left[\left(\theta+\theta^{*}\right) \Gamma_{\beta}+\tau\left[\nu \Gamma_{\beta}-\eta \Gamma_{\alpha}\right]\right]^{3}}$.

The denominator is strictly positive. The numerator of this derivative is strictly increasing in $\nu$. When evaluated at $\nu=0$ the term in brackets reduces to

$$
\left.\left.\left(\theta+\theta^{*}\right) \Gamma_{\beta}\left[\left(\theta+\theta^{*}\right) \Gamma_{\beta}-(2 \tau+\theta) \Gamma_{\alpha}\right)\right]+\eta \tau \Gamma_{\alpha}\left[\left(\theta+\theta^{*}\right) \Gamma_{\beta}-\theta \Gamma_{\alpha}\right)\right]
$$

which is positive because $\Gamma_{\beta}>\Gamma_{\alpha}$ and because $\theta^{*}>2 \tau$ by assumption 2 . Hence, for all values of $\nu$ and $\eta$ we have that $\frac{\partial^{2} \ell_{M}}{\partial \tau \partial \eta}>0$.

(ii) After some algebra we have that

$$
\frac{\partial^{2} \ell_{M}}{\partial \tau \partial \nu}=\frac{\Gamma_{\alpha} \Gamma_{\kappa} \Gamma_{\beta}\left[\left(\theta+\theta^{*}\right) \Gamma_{\beta}[(1-\eta) 2 \tau+\theta]-\theta \tau\left(\nu \Gamma_{\beta}-\eta \Gamma_{\alpha}\right)\right]}{A M\left[\left(\theta+\theta^{*}\right) \Gamma_{\beta}+\tau\left[\nu \Gamma_{\beta}-\eta \Gamma_{\alpha}\right]\right]^{3}} .
$$

The numerator of this derivative is strictly decreasing in $\nu$ and in $\eta$. When evaluated at $\nu=\eta=1$ the term in brackets reduces to $\theta\left[\left(\theta+\theta^{*}\right) \Gamma_{\beta}-\tau\left(\Gamma_{\beta}-\Gamma_{\alpha}\right)\right]$ which is positive because $\Gamma_{\beta}>\Gamma_{\alpha}$ and because $\theta^{*}>2 \tau$. Hence, for all values of $\nu$ and $\eta$ we have that $\frac{\partial^{2} \ell_{M}}{\partial \tau \partial \nu}>0$. 
(iii) When evaluated at $\eta=0$, we have that

$$
\frac{\partial \ell_{M}}{\partial \tau}=\frac{\Gamma_{\alpha} \Gamma_{\kappa}\left[-(1-\nu) \theta-\theta^{*}\right]}{A M \Gamma_{\beta}\left[\left(\theta+\theta^{*}+\tau \nu\right)\right]^{2}}<0
$$

(iv) When evaluated at $\eta=1$, we have that

$$
\frac{\partial \ell_{M}}{\partial \tau}=\frac{\Gamma_{\alpha} \Gamma_{\kappa}\left[\left(\theta\left(\nu \Gamma_{\beta}-\Gamma_{\alpha}\right)\right)\right]}{A M\left[\left(\theta+\theta^{*}\right) \Gamma_{\beta}+\tau\left[\nu \Gamma_{\beta}-\Gamma_{\alpha}\right]\right]^{2}}
$$

which is strictly positive if $\nu>\frac{\Gamma_{\alpha}}{\Gamma_{\beta}}=1-\frac{\beta}{(\alpha+\beta)(1-\alpha)}$, and because $\Gamma_{\alpha}<\Gamma_{\beta}$ we have that $\frac{\Gamma_{\alpha}}{\Gamma_{\beta}}<1$

$(v)$ After some algebra we have

$$
\frac{\partial \ell_{M}^{*}}{\partial \tau}=\frac{\Gamma_{\alpha} \Gamma_{\kappa}\left[\left(\theta^{*}\left(\nu \Gamma_{\beta}-\eta \Gamma_{\alpha}\right)\right)+(1-\nu)\left(\theta+\theta^{*}\right) \Gamma_{\beta}\right]}{A M^{*}\left[\left(\theta+\theta^{*}\right) \Gamma_{\beta}+\tau\left[\nu \Gamma_{\beta}-\eta \Gamma_{\alpha}\right]\right]^{2}}
$$

The numerator of this derivative is strictly decreasing in $\nu$. When evaluated at $\nu=1$ it reduces to $\Gamma_{\alpha} \Gamma_{\kappa} \theta^{*}\left(\Gamma_{\beta}-\eta \Gamma_{\alpha}\right)>0$. Hence, $\frac{\partial \ell_{M}^{*}}{\partial \tau}>0$.

Proposition (4) contains the main result and shows that remittances are different than aid if they are distributed among differing groups of the population. I expect to find that remittances (whose distribution is skewed to poorer inhabitants, and is therefore represented by a larger $\eta$ ) have a stronger effect on manufacturing growth than does aid (represented by a lower $\eta$ ). Proposition (4) also suggests that the effect of aid, and of remittances, depends on whether the donor is a major trading partner of the recipient, however, as most countries trade with many partners and receive transfers from many sources, the relevance of this result would be greatly reduced in a many country model. On the other hand, the income effect only depends on the recipient country and would still obtain in a many country framework. Proposition (4) is written for the case when both the home and foreign countries produce manufactured goods and services. It is of some interest to understand when the manufacturing sector is operational. In proposition (5) I also note the effect of the initial income distribution in the home country on the effect of the transfer. 
Proposition 5. (i) The size of the home manufacturing sector is increasing (and that of the foreign manufacturing sector is decreasing) in the equality of the initial income distribution. (ii) The home manufacturing sector is operational in the absence of a transfer if its initial income distribution is more equal, its endowment is smaller, and that of the foreign country is larger. The foreign country manufacturing sector is operational in the absence of a transfer if the home country's initial income distribution is less equal, the foreign country endowment is smaller and that of the home country is larger.

(iii) The absolute value of the effect of the transfer on the home country's manufacturing industry is increasing in the equality of the initial income distribution.

Proof. ( $i$ ) After some algebra we have that

$$
\frac{\partial \ell_{M}}{\partial \kappa}=\frac{\left.M\left[\left(\theta+\theta^{*}\right) \Gamma_{\beta}-\theta \Gamma_{\alpha}\right)\right][\gamma(1-\alpha)-A \alpha]}{A M\left[\left(\theta+\theta^{*}\right) \Gamma_{\beta}+\tau\left(\nu \Gamma_{\beta}-\eta \Gamma_{\alpha}\right)\right]}>0
$$

and that

$$
\frac{\partial \ell_{M}^{*}}{\partial \kappa}=\frac{-M \Gamma_{\alpha}\left[\theta^{*}-\tau(1-\nu)\right][\gamma(1-\alpha)-A \alpha]}{A M^{*}\left[\left(\theta+\theta^{*}\right) \Gamma_{\beta}+\tau\left(\nu \Gamma_{\beta}-\eta \Gamma_{\alpha}\right)\right]}<0
$$

where I use $\frac{\partial \Gamma_{\kappa}}{\partial \kappa}=M \frac{\partial g(\kappa)}{\partial \kappa}=M[\gamma(1-\alpha)-A \alpha]>0$ by assumption 1 .

(ii) It is easy to see that

$$
\frac{\partial \ell_{M}}{\partial \theta}=\frac{-\Gamma_{\alpha} \Gamma_{\kappa} \theta^{*}}{A M \Gamma_{\beta}\left(\theta+\theta^{*}\right)^{2}}<0
$$

and

$$
\frac{\partial \ell_{M}^{*}}{\partial \theta}=\frac{-\Gamma_{\alpha} \Gamma_{\kappa} \theta}{A M^{*} \Gamma_{\beta}\left(\theta+\theta^{*}\right)^{2}}<0
$$

Also from the partial derivatives in parts $(i)$ and $(i i)$ we can see that there exists a $\hat{\kappa}\left(\theta, \theta^{*}\right)$ such that $\ell_{M}>0$ if and only if $\kappa>\hat{\kappa}\left(\theta, \theta^{*}\right)$ and where $\hat{\kappa}\left(\theta, \theta^{*}\right)$ is decreasing in $\theta$ and increasing in $\theta^{*}$.

(iii) We can show that

$$
\frac{\partial^{2} \ell_{M}}{\partial \tau \partial \kappa}=\frac{\partial \ell_{M}}{\partial \tau} \frac{1}{\Gamma_{\kappa}} M[\gamma(1-\alpha)-A \alpha]
$$


so that

$$
\left|\frac{\partial^{2} \ell_{M}}{\partial \tau \partial \kappa}\right|=\left|\frac{\Gamma_{\alpha}\left[\left(\theta\left(\nu \Gamma_{\beta}-\eta \Gamma_{\alpha}\right)\right)-(1-\eta)\left(\theta+\theta^{*}\right) \Gamma_{\beta}\right]}{A M\left[\left(\theta+\theta^{*}\right) \Gamma_{\beta}+\tau\left[\nu \Gamma_{\beta}-\eta \Gamma_{\alpha}\right]\right]^{2}}\right| M[\gamma(1-\alpha)-A \alpha]>0
$$

Proposition 5 deals with the corner solutions that were ignored in the main results in proposition 4. The manufacturing sector is operational in all countries in my data set. Although proposition 5 is provided for completeness, an interesting implication of this model is given by part (iii) of proposition 5. This third part demonstrates that the good or bad effect of transfer is magnified if the home initially has a more equal income distribution. Hence, remittances should have a stronger positive effect in recipient countries that have a more equal income distribution. If aid is distributed narrowly enough to have a negative effect, then the marginal effect will be smaller in countries where all other income is distributed narrowly.

We now consider the time element of this model and examine the dynamic effect of a transfer. In particular, it is shown that through learning-by-doing any current period effect of a transfer will be reinforced in future periods.

Proposition 6. If a time s transfer increases the size of the manufacturing industry in period $\mathrm{s}$ then it will generate further increases in all future periods. If the period $\mathrm{s}$ transfer reduces the manufacturing industry in period $\mathrm{s}$, then it will further reduce it in all future periods.

Proof. In period $z>s$ we have that

$$
\frac{\partial \ell_{M z}}{\partial \tau_{s}}=\frac{\partial \ell_{M z}}{\partial M_{z}} \frac{\partial M_{z}}{\partial \tau_{s}}=\frac{\partial \ell_{M z}}{\partial M_{z}} \int_{s}^{z} \delta \frac{\partial q_{M t}}{\partial \ell_{M t}}\left[\frac{\partial \ell_{M t}}{\partial M_{t}}+\frac{\partial \ell_{M t}}{\partial \tau_{t}}\right] d t
$$

From equation (21) it is straightforward to see that

$$
\frac{\partial \ell_{M t}}{\partial M_{t}}=\frac{\Gamma_{\alpha} \Gamma_{\kappa}\left[\theta+\tau_{t}(1-\eta)\right]}{A M_{t}^{2}\left[\left(\theta+\theta^{*}\right) \Gamma_{\beta}+\tau_{t}\left(\nu \Gamma_{\beta}-\eta \Gamma_{\alpha}\right)\right]}>0
$$


and $\frac{\partial \ell_{M t}}{\partial \tau_{t}}$ was the focus of proposition 4 .

From proposition 6 we see that if foreign aid generates a current period reduction in manufacturing, then this effect is reinforced in later periods and can be termed as a Dutch disease. On the other hand, if it increases current manufacturing output, then this effect will be magnified and generate a healthy effect.

\subsection{Natural Resource Rent Distribution and Manufacturing Firms}

In this section an extension to the model in section 2.2 is provided. Through this extension

I analyze the effect of windfalls (mainly a resource rent) on the behaviour of firms. As a result, I relax the assumption of perfect competition in the manufacturing sector and instead consider monopolisticly competitive firms in this sector, in both home and foreign regions.

\subsubsection{International Trade}

Similar to section 2.2 I consider heterogeneous individuals where the source of this heterogeneity is the different income levels. In particular, a measure $\kappa$ of the otherwise identical agents are endowed with the numeraire good and I call them the rich whereas $1-\kappa$ who are the poor, do not own the numeraire. Thus, I can maintain the tractability of a single factor model for production while allowing for income differences. There are $L=L^{*}$ individuals in the home (foreign) region. The otherwise identical individuals in both regions inelastically supply their effective labour at the prevailing wage and have preferences over manufactured goods, services, and a numeraire good. These preferences are represented as

$$
u\left(d_{S}, d_{M}, d_{O}\right)=\left(d_{S}+\gamma\right)^{\alpha}\left(d_{M}\right)^{\beta}\left(d_{O}\right)^{1-\alpha-\beta}
$$

With the following sub-utility function in the manufacturing sector

$$
d_{M}=\left(\int_{0}^{N+N^{*}} d_{M}(z)^{\frac{\sigma-1}{\sigma}} d z\right)^{\frac{\sigma}{\sigma-1}}
$$


Where $N\left(N^{*}\right)$ is the total number of manufacturing firms each producing one good of variety $z$. I maintain the Stone-Geary assumption with $\gamma>0$ for services to be able to make meaningful statements about the income distribution as discussed before.

Each firm producing in the monopolistically competitive sector has the same technology

$$
\ell_{z}=a q_{z}+f, \quad \ell_{z}^{*}=a q_{z}^{*}+f
$$

Where $\ell_{z}$ is the amount of labour used in producing good $z, q_{z}$ is the quantity supplied of $\operatorname{good} \mathrm{z}, a$ is the inverse of marginal productivity of labour used in manufacturing, and $f$ denotes the fixed input requirement. I use the convention that the fixed cost of production, $f$, is paid in terms of labour. Also, we note that the total demand for manufacturing labour

is given by $\ell_{M}=\int_{0}^{N} \ell_{z} d z\left(\ell_{M}^{*}=\int_{0}^{N^{*}} \ell_{z}^{*} d z\right.$ in foreign). The technology for producing services is given by $\ell_{S}=b q_{S}\left(\ell_{S}^{*}=b q_{S}\right.$ in foreign) where $b$ is the unit labour requirement in services. Finally, the technology for producing the numeraire good is $\ell_{O}=q_{O}\left(\ell_{O}^{*}=q_{O}^{*}\right.$ in foreign $)$ where unit input requirement is equal to 1.

Per capita income is generated by the wage paid to labour, $w$, as well as an endowment of numeraire good which unequally distributed. In particular, per capita income in the home region is given as $I^{R}=w+\frac{\theta}{\kappa}$ for the $\kappa$ rich individuals and $I^{P}=w$ for the $(1-\kappa)$ poor individuals. There is no inequality in the foreign region and per capita income is $I^{*}=w+\theta$. Labour is perfectly mobile and each individual supplies their labour inelastically to the firm paying the highest wage, so that the wage is equalized across sectors and is equal to the price of the numeraire good which is normalized to one.

Individuals choose their purchases of manufactured, services, and the numeraire to maximize their utility function in equation (23) subject to the budget constraint. This maximization yields the demand functions described in equation (3). Using equilibrium prices for the services $\left(P_{S}=b w\right)$ that will be derived below and the fact that in the equilibrium $\left(P_{O}=\right.$ $w=1$ ) we can re-write assumption 1 introduced in section 2.3 as assumption 4 below.

\section{Assumption 4.}

$$
w<\frac{P_{S} \gamma(1-\alpha)}{\alpha}=I^{0}<w+\theta
$$




$$
1<\frac{\gamma(1-\alpha)}{A \alpha}<1+\theta
$$

As shown by Dixit and Stiglitz (1977), the set of purchased manufactured goods can be considered as a composite good $d_{M}$ with the following home price index.

$$
P_{M}=\left(\int_{0}^{N+N^{*}} p_{z}^{1-\sigma} d z\right)^{\frac{1}{1-\sigma}}
$$

Where $p_{z}$ is the supply price in the home country. With international trade, as in previous sections, although services are assumed non-tradable, the manufactured goods and the numeraire are considered traded. Whereas the numeraire is freely traded without cost, manufactured goods have an iceberg trade cost of $\tau=\lambda(1+t)>1$. In particular, if one unit is shipped from foreign, the $\frac{1}{\tau}$ will arrive at the destination. The remaining $\frac{\tau-1}{\tau}$ melts away. The term $\lambda$ is the common transport cost between home and foreign. The tarriff on products that home imports from foreign is $t$. The total trade cost for goods imported into foreign is the same $\tau=\tau^{*}$. Hence, by restricting tariffs to also be of the iceberg variety I am assuming away any income expenditure effect of tariff revenue. ${ }^{26}$ Given this formulation the foreign importer price of a manufactured good $z$ that is produced at home is $p_{z}^{m *}=\tau p_{z}$. The home importer price of manufactured good $z$ that is produced in foreign is $p_{z}^{m}=\tau p_{z}^{*}$. Consequently, the home price index can be re-written as the following.

$$
P_{M}=N p_{z}^{1-\sigma}+N^{*}\left(\tau p_{z}^{*}\right)^{1-\sigma}
$$

Consumer maximization of the sub-utility function in home and foreign yields the following conditions

$$
d_{z}=\left(\frac{p_{z}^{-\sigma}}{P_{M}^{1-\sigma}}\right) R, \quad d_{z}^{*}=\left(\frac{p_{z}^{*-\sigma}}{P_{M}^{* 1-\sigma}}\right) R^{*}
$$

Where $R\left(R^{*}\right)$ is aggregate manufacturing expenditures in home (foreign) country and is expressed in equation (30) below.

\footnotetext{
${ }^{26}$ This formalization of the combination of a given iceberg transport cost and a chosen iceberg tariff is introduced by Ossa (2011).
} 


$$
\begin{aligned}
R=P_{M} d_{M} & =\frac{\beta L\left[(1-\alpha \kappa) w+(1-\alpha) \kappa\left(\frac{\theta}{\kappa}+p_{s} \gamma\right)\right]}{1-\alpha} \\
R^{*} & =P_{M}^{*} d_{M}^{*}=\beta L^{*}\left(w+\theta^{*}+p_{s} \gamma\right)
\end{aligned}
$$

Moreover, the prohibitive transport cost on services allows the prices of these non-tradables to differ across borders, however, their simple technology yields $P_{S}=b w$, so that (in the equilibrium) the price of services is the same in both countries. Using the services pricing rule and the manufacturing aggregate prices, the demand equations for a home manufactured $\operatorname{good} z$ in both home and foreign are

$$
\begin{gathered}
d_{M}(z)=\frac{\beta L p_{z}^{-\sigma}[(1-\alpha \kappa) w+(1-\alpha)(\theta+\kappa \gamma b w)]}{(1-\alpha)\left(N p_{z}^{1-\sigma}+N^{*}\left(\tau p_{z}^{*}\right)^{1-\sigma}\right)} \\
d_{M}^{*}(z)=\frac{\beta L^{*}\left(\tau p_{z}\right)^{-\sigma}\left[\theta^{*}+w(1+b \gamma)\right]}{N\left(\tau p_{z}\right)^{1-\sigma}+N^{*} p_{z}^{* 1-\sigma}}
\end{gathered}
$$

Demands for foreign manufacturing good $z$ is similar with $p_{z}^{*}$ in numerator. Due to the trade cost, $\tau$ units must be shipped for 1 unit to arrive, so total demand for home manufactureds can be written as $d_{M}(z)+\tau d_{M}^{*}(z)$. Market clearing condition for good $z$ then implies

$$
\begin{aligned}
q_{z}=d_{M}(z)+\tau d_{M}^{*}(z) & =\frac{\beta L p_{z}^{-\sigma}[(1-\alpha \kappa) w+(1-\alpha)(\theta+\kappa \gamma b w)]}{(1-\alpha)\left(N p_{z}^{1-\sigma}+N^{*}\left(\tau p_{z}^{*}\right)^{1-\sigma}\right)} \\
& +\frac{\beta L^{*}(\tau)^{1-\sigma}\left(p_{z}\right)^{-\sigma}\left[\theta^{*}+w(1+b \gamma)\right]}{N\left(\tau p_{z}\right)^{1-\sigma}+N^{*} p_{z}^{* 1-\sigma}}
\end{aligned}
$$

Each manufacturing firm chooses output to maximize profit, and because there is a large number of firms, each takes the output of the other firms and the aggregate price index, $P_{M}$, and consumption, as given. As such, the pricing rule for good $z$ in home and foreign is the same; $p=\frac{a \sigma}{(\sigma-1)}=p_{z}=p_{z}^{*}$.

The free entry condition indicates that revenue for each firm must equal total cost for each firm:

$$
p_{z} q_{z}=r_{z}=\ell_{z}=a q_{z}+f
$$


Where $r_{z}=d_{M} P_{M}^{\sigma}\left(\frac{\sigma-1}{a \sigma}\right)^{\sigma-1}$.

It is immediate to see that the output of each variety is determined uniquely by $\sigma, a, f$ and $w$ and that the price is given by $\sigma, a$ and $w$. In particular, in this formulation the wage is determined by the numeraire good and is not affected by country size or the composition of demand, therefore, neither price nor output per firm are determined by market size or demand composition and as a result $\ell_{z}=\ell_{z}^{*}=\ell$. As it is shown below, it is through its impact on the number of varieties that a windfall will have an effect the two economies. Given the conditions mentioned above, I re-write equation (32) as the following

$$
q_{z}=\frac{\beta L[(1-\alpha \kappa) w+(1-\alpha)(\theta+\kappa \gamma b w)]}{(1-\alpha)\left(N+N^{*} r\right) p}+\frac{r \beta L^{*}\left[\theta^{*}+w(1+b \gamma)\right]}{\left(N r+N^{*}\right) p}
$$

Where $r=\tau^{1-\sigma}$. Using the free condition mentioned in equation (33), and the fact that in the equilibrium $w=1$, I re-write equation (34) as the following expression. In the home region we have

$$
\frac{\ell_{z}}{\beta}=\frac{L}{N+N^{*} r} \Psi(\kappa, \gamma, \theta)+\frac{L^{*} r}{N r+N^{*}} \Omega\left(\gamma, \theta^{*}\right)
$$

Also, for the foreign region the following condition holds.

$$
\frac{\ell_{z}^{*}}{\beta}=\frac{L r}{N+N^{*} r} \Psi(\kappa, \gamma, \theta)+\frac{L^{*}}{N r+N^{*}} \Omega\left(\gamma, \theta^{*}\right)
$$

Where $\Psi(\kappa, \gamma, \theta)=\frac{(1-\alpha \kappa)+(1-\alpha)(\theta+\kappa \gamma b)}{(1-\alpha)}$ and $\Omega\left(\gamma, \theta^{*}\right)=\theta^{*}+1+b \gamma$. Note that if $\kappa=1$ and $\theta=\theta^{*}$, then $\Psi(\kappa, \gamma, \theta)=\Omega\left(\gamma, \theta^{*}\right)$.

Combining equations (35), (36), and $\ell_{z}=\ell_{z}^{*}=\ell$ the numbers of manufacturing firms (or varieties since each firm produces only one variety) in home and foreign are defined.

$$
N=\frac{\beta}{(1-r) \ell_{z}}\left(\Psi L-r \Omega L^{*}\right), \quad N^{*}=\frac{\beta}{(1-r) \ell_{z}}\left(\Omega L^{*}-r \Psi L\right)
$$

Having defined the trading equilibrium, next, I analyze the effects of the resource rents and their distribution on the home manufacturing firms. 


\subsubsection{Resource Rent Distribution and Market Share}

As noted in the previous section, in this framework with a given wage, price, and output per firm are not determined by market size or demand composition. As such, by altering the number of varieties a windfall affects the manufacturing sector. To this end, I define two variables related to $N$ and $N^{*}$; First is the "market share" of a home manufacturing firm

$s_{N}=\frac{N}{N+N^{*}}$. I also define a "size share" variable as $s_{L}=\frac{\Psi L}{\Psi L+\Omega L^{*}}$ which depends on the size of the home region relative to the world and the expenditure parameters $\Psi$ and $\Omega$. With some algebra I can show that the market share can be written as a function of the size share for a single manufacturing firm.

$$
\begin{aligned}
s_{N} & =\frac{\Psi L-r \Omega L^{*}}{(1-r)\left(\Psi L+\Omega L^{*}\right)} \\
& =\frac{(1+r) s_{L}-r}{1-r}
\end{aligned}
$$

The firm's market share then solely depends on how large the market size is. In particular, the following gives us the range by which the market share varies.

$$
s_{N}=\left\{\begin{array}{lll}
0 & \text { if } & s_{L} \leq \frac{r}{1+r} \\
\frac{(1+r) s_{L}-r}{1-r} & \text { if } & \frac{r}{1+r}<s_{L}<\frac{1}{1+r} \\
1 & \text { if } & s_{L} \geq \frac{1}{1+r}
\end{array}\right.
$$

Equation (39) indicates that in order to study how the market share is altered by a windfall, it would be sufficient to learn about the changes in the size share. Also, I am able to analyze the resulting changes from the transport cost. In particular, the partial derivative of (38) indicates that the marginal effect of the size share on the market share is direct and proportional regardless of the expenditures composition.

$$
\frac{\partial s_{N}}{\partial s_{L}}=\frac{1+r}{1-r}>1
$$

Consequently, resource rents distribution would affect the market share of a home firm 
(relative to the world), by changing the home country's share of the size of its labour market. Proposition 7 formally states these results.

Proposition 7. (i) An increase (decrease) in the resource rents in the home country will increase (decrease) the market share of the home country's manufacturing firms.

(ii) A more equal (unequal) distribution of the rents in the home country will increase (decrease) the market share of the home country's manufacturing firms.

Proof. ( $i$ ) Using equation (40) I can sign the following derivative as positive.

$$
\begin{aligned}
\frac{\partial s_{N}}{\partial \theta} & =\left(\frac{\partial s_{N}}{\partial s_{L}}\right)\left(\frac{\partial s_{L}}{\partial \Psi}\right)\left(\frac{\partial \Psi}{\partial \theta}\right) \\
& =\left(\frac{1+r}{1-r}\right) \frac{\left(\Psi L+\Omega L^{*}\right) L-\Psi L^{2}}{\left(\Psi L+\Omega L^{*}\right)^{2}} \\
& =\frac{\Omega L^{*} L}{\left(\Psi L+\Omega L^{*}\right)^{2}}>0
\end{aligned}
$$

(ii) Using equation (40) and the fact that by assumption $4 \frac{\partial \Psi}{\partial \kappa}>0$, I can sign the following derivative as positive.

$$
\begin{aligned}
\frac{\partial s_{N}}{\partial \kappa} & =\left(\frac{\partial s_{N}}{\partial s_{L}}\right)\left(\frac{\partial s_{L}}{\partial \Psi}\right)\left(\frac{\partial \Psi}{\partial \kappa}\right) \\
& =\left(\frac{1+r}{1-r}\right) \frac{\left(\Psi L+\Omega L^{*}\right) L-\Psi L^{2}}{\left(\Psi L+\Omega L^{*}\right)^{2}}\left(\frac{b \gamma(1-\alpha)-\alpha}{1-\alpha}\right) \\
& =\frac{\Omega L^{*} L}{\left(\Psi L+\Omega L^{*}\right)^{2}}\left(\frac{b \gamma(1-\alpha)-\alpha}{1-\alpha}\right)>0
\end{aligned}
$$

Finally, proposition 8 formally states that the effects of the transport cost on the market share would depend on the relative size of the country (i.e. $\frac{\Psi L}{\Omega L^{*}}$ ) which by itself is defined by the resource endowment and the distribution.

Proposition 8. (i) If the home country is relatively large (small) compared to the foreign country, then a reduction in transport cost increases (decreases) the market share of the home country's manufacturing firms. If the home and foreign countries initially have the 
same size then changes in the transport cost do not affect the market share of the home country's manufacturing firms.

(ii) A worsening of the resource rents distribution can decrease the size of the home economy relative to that of the foreign.

Proof. ( $i$ ) Using equation (40) and the fact that $r$ and $\tau$ are inversely related, the following derivative has a positive sign.

$$
\frac{\partial s_{N}}{\partial r}=\frac{(1-r)\left(s_{L}-1\right)+(1+r) s_{L}-r}{(1-r)^{2}}=\frac{2 s_{L}-1}{(1-r)^{2}}
$$

To indicate the sign of the derivative above we must determine how the size share of the home country is compared to $\frac{1}{2}$ in this 2-country model. More specifically

$$
\frac{\partial s_{N}}{\partial r}\left\{\begin{array}{lll}
<0 & \text { if } & \Psi L<\Omega L^{*} \\
=0 & \text { if } & \Psi L=\Omega L^{*} \\
>0 & \text { if } & \Psi L>\Omega L^{*}
\end{array}\right.
$$

(ii) Note that by replacing $\Psi$ and $\Omega$ in $\Psi L \geq \Omega L^{*}$ we have the following equation.

$$
\frac{(1-\alpha \kappa)+(1-\alpha)(\theta+\kappa \gamma b)}{(1-\alpha)(1+\theta+b \gamma)} \geq \frac{L^{*}}{L}
$$

If there is no inequality $(\kappa=1)$ then the left hand side of equation (45) is equal to 1 . As $\kappa$ decreases the left hand side term also decreases. Evaluated at $\kappa=0$, equation (45) is written as

$$
\frac{(1-\alpha) \theta+1}{(1-\alpha)(1+\theta+b \gamma)} \geq \frac{L^{*}}{L}
$$

The left hand side of equation (46) is less than 1 by assumption 4 . This implies that with more unequal resource rents distribution in the home country (which is at least the same size of the foreign), the relative size of the home economy shrinks. For a large enough change in $\kappa$ and due to the free factor movement, the relative size of an initially large home economy can even reverse. Finally, in the case of an initially small economy $\Psi L<\Omega L^{*}$ and unequal 
distribution further negatively contributes to the relative size of the country and make it even smaller.

All in all, it can be inferred from proposition 8 that a worsening of the distribution of resource rents reduces the size of the country, and that by itself can exacerbate the negative effects of a lower trade cost on the domestic traded sector and result in more reliance on the imports in that sector.

\subsection{Conclusion}

In this chapter, I demonstrate that the Dutch disease may arise solely from the distribution of windfalls. If the resource rents are less widely distributed, then the Dutch disease is more pronounced. In fact, the resource rents distribution can take precedence in determination of the Dutch disease. Likewise, I show that not all types of foreign transfers contribute to the Dutch disease. In fact, whereas foreign aid can generate a Dutch disease, remittances can benefit the economy. This difference once again lies on how the transfers are distributed. Aid being usually paid directly to the governments, tend to be spent by the rich on luxury less tradable services. Whereas remittances find its way to the poor segment of the population and can help the production of traded goods. The results suggest why some countries, therefore, have a greater chance of suffering the curse.

Apart from the focus on non-homothetic preferences, the model in section 2.4 and 2.5 is similar to that in Krugman (1987), Neary (1988), Torvik (2001), Goderis and Malone (2011), van der Ploeg and Venables (2013), and Beine, Coulombe and Vermeulen (2015) in that the numeraire sector does not use any labour (it is a pure economic windfall that is equivalent

to a foreign transfer), however, it differs in that the numeraire is consumed and can be traded. In this way my framework is closer to Corden and Neary (1982), however, they also allow for their energy sector to employ factors of production (except when they turn off this possibility in order to concentrate solely on the spending effect). Although ignoring labour employment in the natural resource sector simplifies the exposition of my model (which works only through the spending effect), it also mirrors the empirical observation that in 
some countries a natural resource boom does not generate a large shift of labour towards the resource sector. ${ }^{27}$ Nevertheless, I relax this assumption in section 2.5 to study the effect of windfalls on the number of manufacturing firms. I then consider production in the numeraire sector with an exogenous wage for exposition of the model. As a result, although the relative wage channel is shut down, the windfall still affects the economy through the market share of the manufacturing firms.

As Beine, Coulombe and Vermeulen (2015) show, interprovincial and temporary worker immigration mitigate the Dutch disease effects of natural resource booms in western Canada. The results in this chapter also suggest that the mitigating effects of immigration may also depend on the share of the natural resource rents distributed to the economic migrants and may, therefore, be stronger in a more egalitarian country such as Canada.

\footnotetext{
${ }^{27}$ As noted by Brahmbhatt, Canuto, and Vostroknutova (2010) this resource movement effect is less prevalent in low-income countries. Furthermore, in many of the wealthy gulf oil states in the Middle East the workers are brought in from abroad. As shown by Kapiszewski (2006) the percentage of foreign-born workers in Kuwait, Qatar and the UAE (in 2004) are 64, 70, and 81 percent of the total population. A similar example is given by many South American countries where mining constitutes a large part of export revenues, but employs a very small part of the population. For example, mining made up 59 percent of Peru's exports in 2011 but employed only 1 percent of the labor force (Calfucura, Ortiz, Sanborn, and Dammert, 2013).
} 


\section{Chapter 3: Does Inequality Drive the Dutch Dis- ease? Empirical Evidence.}

\subsection{Introduction}

The empirical literature on the estimation of the Dutch disease and the resource curse begins with Sachs and Warner (1997a, 1997b, 2001) who find strong evidence of the Dutch disease. Mehlum, Moene and Torvik (2006) extend their analysis to consider the interaction between institutional quality and natural resource abundance. I replace their resource abundance measure (which includes food, beverages, animal and plant products, as well as energy and precious metals) with natural resource rents (which only includes energy, precious metals, and forestry products). This narrower measure of natural resources refutes the hypothesis that natural resources by themselves can cause the Dutch disease. It is only when interacted with inequality that the effect can be negative. Brunnschweiler and Bulte (2008), van der Ploeg and Poelhekke (2010), and Collier and Goderis (2012) also propose different measures of natural resources that should not suffer the same endogeneity problems as that used by Sachs and Warner and Mehlum et al. and, like us, they find that natural resources by themselves do not cause a disease. In addition to my narrower measure of natural resources which does not include agriculture (a large source of the endogeneity, since poor countries are always dependent on agriculture) I treat the possible endogeneity of each of the independent variables through the use of Arellano-Bond (1991) and Blundell-Bond (1998) estimation techniques. An important contribution to this literature is my test of the relationship between natural resource rent distribution and the Dutch disease. ${ }^{28}$ In order to isolate country heterogeneity, capture annual changes, and deal with the possible endogeneity of the regressors, I utilize a dynamic panel analysis with Arellano-Bond and Blundell-Bond general method of moments (GMM) estimators.

In addition, I consider the relationship between institutional quality and income inequality

\footnotetext{
${ }^{28} \mathrm{~A}$ nice overview of the empirical literature on the Dutch disease and the resource curse is provided by van der Ploeg (2011).
} 
and show that my results are robust to a similar regression where inequality is replaced by the residuals of a regression of inequality on institutional quality and its squared term. My empirical findings in all of the estimation procedures support my hypothesis that the Dutch disease is directly linked with how well the natural resource rents are distributed. Natural resource rents by themselves positively impact growth, however, the interaction of rents with their distribution shows that there is a critical level of my inequality measure. Whether inequality is above or below this level plays a significant role in whether being resource-rich is a blessing or a curse for a country.

I start by testing the theoretical predictions of the model in section 2.3 to find out if they are supported by the data. In particular, I test how changes in national income (or GDP) are affected by natural resource rents and their distribution. Using equation (10) and the fact that current manufacturing productivity is a function of some initial level as well as the past history of resource rents and their distribution, I can write the equation that forms the basis of my estimation strategy as

$$
G D P_{t}=I_{t}=w_{t}+\theta_{t}=f\left(M_{t}, M_{t}^{*}, \kappa, \theta_{t}, \theta_{t}^{*}\right)=f\left(M_{0}, M_{0}^{*}, \kappa,\left\{\theta_{\tau}\right\}_{\tau=0}^{t},\left\{\theta_{\tau}^{*}\right\}_{\tau=0}^{t}\right)
$$

From equation (10) we see that

$$
\frac{\partial I_{t}}{\partial \theta_{t}}>0>\frac{\partial I_{t}^{2}}{\partial \theta_{t} \partial \kappa}
$$

The partial derivatives indicate that an increase in the current period natural resource rents should increase current GDP, however, this positive effect is mitigated by a less equal distribution. Given the reduction in learning by doing that it entails the theory predicts that the negative effect would be more evident for past period resource booms. 
An OLS regression that could capture my coefficients of interest is given by equation (48). ${ }^{29}$

$$
\begin{aligned}
\left(\log G D P_{i t}-\log G D P_{i t-1}\right) & =\beta_{0}+\left(\beta_{1}-1\right) \log G D P_{i t-1}+\beta_{2} N r_{i t}+\beta_{3}\left(G i n i_{i} \cdot N r_{i t}\right) \\
& +\beta_{4} X_{i t}+\delta_{i}+\delta_{t}+\varepsilon_{i t}
\end{aligned}
$$

The variable $\log G D P_{i t}$ has subscript $i$ for country and $t$ for year. Economic growth is measured by the annual changes in the log of GDP per capita and is expressed in percentages. Gini $_{i}$ is the reported Gini coefficient from the World Bank World Development Indicators (WDI, 2013), which is averaged over 1965-2008 and indexed between 0 to 1 . The data for natural resource rents, $N r_{i t}$, is also from the WDI (2013). The interaction term of interest is $\left(\right.$ Gini $\left._{i} \cdot N r_{i t}\right)$ with $\beta_{3}$ as its coefficient, which is expected to be negative. My theory also predicts that $\beta_{2}$ is positive. $X_{i t}$ is a vector of other explanatory variables that will be discussed below. Finally, $\delta_{i}$ and $\delta_{t}$ are country and year fixed effects, respectively. I could also perform the same estimation with the lag of natural resource rents as well as its interaction with the Gini coefficient to test whether the effects appear after a year is passed. This regression in equation (14), however, is inconsistent because the lag of GDP is used as a regressor both directly and indirectly as the denominator of the natural resource rents variable. In addition, many of the additional variables included in $X_{i t}$ could also be endogenously determined by the growth of GDP. Hence, in order to control for the potential endogeneity of the regressors, to isolate country heterogeneity, and to capture annual changes while dealing with possible inconsistencies associated with the fixed effects estimation I utilize dynamic panel analyses. I start first with Arellano-Bond estimators and then proceed to use BlundellBond estimators. For a dynamic growth panel such as the one used in this analysis, Bond, Hoeffler, and Temple (2001), show that the Blundell-Bond approach provides more reliable

\footnotetext{
${ }^{29}$ This theory also supports an estimation where changes in the employment shares in manufacturing sector is used as the dependent variable. I prefer to use the GDP growth rate as the dependent variable for three reasons. First, the data on the employment share of manufacturing is noisy, and there is a lot of missing observations for the time period of the study. Second, the existing data indicates a continuous decline in employment shares in the manufacturing sector for almost all countries. This decline could be caused by other general factors such as non-uniform labor-saving technological change, which are less relevant for my purposes (i.e. income distribution and natural resources). Finally, since the majority of the previous empirical work on the Dutch disease and the resource curse makes use of a growth equation, employing the same approach enables us to compare my results with those.
} 
estimates. This result is confirmed in my analysis because the Blundell-Bond estimators in tables 9 and 10 do not suffer from the weak instruments that plague the Arellano-Bond estimators in column (1) of tables 6 and 8.

Before describing my estimation procedure, I define the rest of my explanatory variables that are included in $X_{i t}$. These variables include the log of the fertility rate, government consumption as a share of GDP, inflation (annual percentage), investment, the annual growth rate of the terms of trade, and the log of initial per capita GDP squared.

Table 1: Definitions and Sources of the Variables

\begin{tabular}{|c|c|c|}
\hline Variables & Definition and Comments & $\begin{array}{l}\text { Source (World Bank, } \\
\text { WDI (2013) for the } \\
\text { period 1965-2008 } \\
\text { unless specified) }\end{array}$ \\
\hline Log of real GDP per capita & Measured in constant 2005 US\$. & \\
\hline Natural resource rents & $\begin{array}{l}\text { Total natural resources rents ( } \% \text { of GDP). Total natural resources rents are the sum } \\
\text { of oil rents, natural gas rents, coal rents (hard and soft), mineral rents, and forest } \\
\text { rents. }\end{array}$ & \\
\hline Gini coefficient $(1965-2008)$ & $\begin{array}{l}\text { Average of Gini index between the years } 1965-2008 \text {. A Gini index of } 0 \text { represents } \\
\text { perfect equality, while an index of } 1 \text { implies perfect inequality. }\end{array}$ & $\begin{array}{l}\text { World Bank } \\
\text { estimates }(2013)\end{array}$ \\
\hline Institutional quality & $\begin{array}{l}\text { Average of } 6 \text { variables; Corruption in government, Rule of law, Bureaucratic } \\
\text { quality, Ethnic tensions, Repudiation of contracts by government, Risk of } \\
\text { expropriation indexed between } 0 \text { and } 10 \text { (10 represents highest quality of } \\
\text { institutions.) for the period } 1982-1997 .\end{array}$ & $\begin{array}{l}\text { Knack and Keefer } \\
\text { (1998), ICRG data } \\
\text { set }\end{array}$ \\
\hline Log of fertility rate & $\begin{array}{l}\text { Logarithm of the total fertility rate or births per woman; representing the number of } \\
\text { children that would be born to a woman if she were to live to the end of her } \\
\text { childbearing years and bear children in accordance with current age-specific } \\
\text { fertility rates. }\end{array}$ & \\
\hline Government consumption & General government final consumption expenditure ( $\%$ of GDP). & \\
\hline Inflation & $\begin{array}{l}\text { GDP implicit deflator (annual \%) is the ratio of GDP in current local currency to } \\
\text { GDP in constant local currency. }\end{array}$ & \\
\hline Investments & Gross capital formation ( $\%$ of GDP). & \\
\hline Growth rate of terms of trade & $\begin{array}{l}\text { Annual changes in the net barter terms of trade index calculated as the percentage } \\
\text { ratio of the export unit value indexes to the import unit value indexes, measured } \\
\text { relative to the base year } 2000 \text {. }\end{array}$ & \\
\hline
\end{tabular}

To be consistent with other cross sectional analyses, I also include institutional quality and its interaction with natural resource rents in my fixed effect model. This variable is an index between 0 and 1 with a higher value indicating better institutions. It is an average of 6 different variables (corruption in government, rule of law, bureaucratic quality, ethnic ten- 
sions, repudiation of contracts by government, risk of expropriation) compiled by Knack and Keefer (1998). The data for these six institutional quality variables is from the International Country Risk Guide (ICRG) database for the period 1982-1997 and the data for the other variables is from WDI (2013). The details and definitions of these variables are provided in table 1.

In addition, table 2 contains summary statistics for these variables and the list of the countries in my data set can be found in table 3 .

Table 2: Summary Statistics

\begin{tabular}{lccccc}
\hline Variables & $\begin{array}{c}\text { Number of } \\
\text { observations }\end{array}$ & Mean & $\begin{array}{c}\text { Standard } \\
\text { Deviation }\end{array}$ & Minimum & Maximum \\
\hline Real GDP per capita Growth (annual rate) & 959 & 0.00708 & 0.0489 & -0.317 & 0.182 \\
Gini coefficient & 61 & 0.454 & 0.0831 & 0.299 & 0.691 \\
Natural resource rents & 963 & 0.0947 & 0.108 & 0.000337 & 0.677 \\
Institutional quality & 935 & 0.540 & 0.142 & 0.200 & 0.956 \\
Log of fertility rate & 976 & 1.510 & 0.374 & 0.464 & 2.051 \\
Government consumption (share of GDP) & 944 & 0.140 & 0.0615 & 0.0298 & 0.545 \\
Inflation (annual \%) & 959 & 1.042 & 7.355 & -0.292 & 136.1 \\
Investment (\% of GDP) & 947 & 0.209 & 0.0762 & 0.0315 & 0.597 \\
Growth rate of terms of trade & 953 & -0.0194 & 0.178 & -1.460 & 1.057 \\
Log of GDP per capita & 1,081 & 7.113 & 1.152 & 4.717 & 10.56 \\
& & & & & \\
\hline
\end{tabular}

There is no known empirical measure of the distribution of natural resource rents and I, therefore, use an average Gini coefficient during the above time period. There are three main reasons for my decision to use an average value of the Gini coefficient. First, my dataset does not cover every year in the sample; however, since the Gini coefficients do not appear to change much over time, I feel comfortable using the averages of the reported years. Second, if I were to use a panel, then I would have a very small one as the data is reported for a small subset of the total years in my sample. Third, I am not interested in annual changes in the inequality index per se, but rather the annual evolution of the natural resource rents interacted with some measure of their inequality of distribution for each country. ${ }^{30}$ Finally,

\footnotetext{
${ }^{30}$ The relationship between income inequality and growth over time is not straightforward. Theoretically, the Kuznets curve suggests that income inequality first increases and then declines as an economy develops. It has also been indicated empirically that this non-linearity generates ambiguous estimation of the effect of inequality on growth. There have been some attempts to pin down this relationship empirically through
} 
Table 3: List of the Countries

\begin{tabular}{llll}
\hline \multicolumn{3}{l}{ Countries with an asterisk are Communist countries and are excluded from the restricted sample. } \\
\hline Algeria & Ecuador & Malawi & South Africa \\
Angola* & Egypt, Arab Rep. & Malaysia & Sri Lanka \\
Argentina & El Salvador & Mali & Tanzania \\
Bangladesh & Ethiopia* & Mexico & Thailand \\
Bolivia & Gabon & Morocco & Togo \\
Botswana & Gambia, The & Mozambique* & Trinidad and Tobago \\
Brazil & Ghana & Namibia & Tunisia \\
Burkina Faso & Guatemala & Nicaragua & Turkey \\
Cameroon & Guinea & Niger & Uganda \\
Chile & Guinea-Bissau & Nigeria & United States \\
China* & Honduras & Pakistan & Uruguay \\
Colombia & India & Panama & Venezuela, RB \\
Congo, Rep. & Indonesia & Paraguay & Zambia \\
Costa Rica & Jordan & Peru & \\
Cote d'Ivoire & Kenya & Philippines & \\
Dominican Republic & Madagascar & Senegal & \\
\hline
\end{tabular}

because the Gini coefficient is a time invariant average, it is isomorphic to the country effects and would be dropped from the panel regression if I tried to separately estimate its effect.

\subsection{Dynamic Panel Analysis}

My estimation procedure needs to address issues of country heterogeneity, short run time effects, and any possible endogeneity between the dependent variable and the predictors of GDP growth. I, therefore, consider the effects of annual changes in the dependent variables on GDP growth, through dynamic panel data analyses. I build on a regression introduced by Barro (2000) that was then modified by Banerjee and Duflo (2003) where they looked at the effect of inequality on growth. In turn, I extend these analyses to also estimate the impact of natural resource rents alone and interacted with inequality. In addition to the use of a difference GMM estimation method introduced by Arellano and Bond (1991), to address

different methods of estimation, and generally the inverted-U shape Kuznets curve is confirmed in the data. In my panel data analysis, however, I am not concerned with the direct effect of inequality on growth or with its functional form. 
potential inconsistency or endogeneity issues I also use a modified system GMM estimation technique introduced by Blundell and Bond (1998). It is worth mentioning that my panel does not suffer a unit root problem and the variables are not necessarily integrated of order one. The results of the unit root tests are provided in table 4.

Table 4: Unitroot Test

\begin{tabular}{|c|c|c|c|c|c|}
\hline & \multirow[t]{2}{*}{ Statistic } & \multirow[t]{2}{*}{ P-value } & \multicolumn{3}{|c|}{ Fixed-N Exact Critical Values } \\
\hline & & & $1 \%$ & $5 \%$ & $10 \%$ \\
\hline$t$-bar & -3.4563 & & -1.820 & -1.730 & -1.690 \\
\hline$\tilde{t}$-bar & -2.4280 & & & & \\
\hline$z$-ẗ-bar & -8.9583 & 0.0000 & & & \\
\hline
\end{tabular}

Notes: Im-Pesaran-Shin (IPS) unit root test is performed for the unbalanced panel. The p-value is reported for the null hypothesis that all panels contain unit roots against the alternative that some panels are stationary. The zero p-value along with the t-bar statistic being less than its $1 \%$ critical value, imply that there is no integration of order one in the panel.

Finally, I also consider the relationship between institutional quality and income inequality, and I show that my findings are robust to a similar regression where inequality is replaced by the residuals of a regression of inequality on institutional quality.

I begin by using a first differenced estimator and instrument the variables using further lags as suggested by Arellano and Bond, where the one period lagged GDP per capita is a predetermined variable. ${ }^{31}$ As a result, the main specification can be expressed as equation (49):

$$
\Delta \log G D P_{i t}=\beta_{1} \Delta \log G D P_{i t-1}+\beta_{2} \Delta N r_{i t}+\beta_{3}\left(G i n i_{i} \cdot \Delta N r_{i t}\right)+\beta_{4} \Delta X_{i t}+\Delta \delta_{t}+\Delta \varepsilon_{i t}
$$

Where $\Delta$ stands for the annual changes. To deal with the contemporaneous correlation of the lagged GDP, as well as the endogeneity of all other variables, I use further lags of the variables (but not the first lag) as instruments. ${ }^{32}$ This is due to the fact that find-

\footnotetext{
${ }^{31}$ All results are computed using xtabond2 command in STATA with collapsed instruments in order to tackle the problem of too many instruments. See Roodman (2009).

${ }^{32} \mathrm{I}$ do not use the first lag because $\left(\log G D P_{i t-1}-\log G D P_{i t-2}\right)$ is correlated with $\left(\varepsilon_{i t}-\varepsilon_{i t-1}\right)$. At the
} 
ing external (non-lagged) instruments that are truly exogenous to GDP growth is generally considered as impossible because almost everything is endogenous to growth. In dynamic growth panel analyses, therefore, the generalized method of moments (GMM) estimation of the first-differenced equations (Arellano-Bond (1991)) with lags are generally used as the best possible instruments (see Barro, 2000). Still, lagged variables are sometimes considered as weak instruments and the system GMM method of Blundell and Bond (1998) is considered to provide more reliable estimates in my type of analysis (see Bond, Hoeffler, and Temple (2001)). In fact, I do find that my results are more consistently significant across specifications when I use Blundell-Bond estimators in section 3.2.2.

\subsubsection{Difference GMM estimation}

Note that using only one instrument for each variable in a difference GMM estimation leads to exact identification of the model and in this case I would be unable to verify the validity of instruments using an over-identification test. To overcome this issue, I increase the number of instruments by using one lag for the predetermined variable (i.e. the initial GDP) and two lags for the other endogenous variables. ${ }^{33}$ Thus, $Z_{i t}$ represents my vector of instruments used in Arellano-Bond estimation

$$
Z_{i t}=\left[\log G D P_{i t-2}, N r_{i t-2}, N r_{i t-3}, G i n i_{i} \cdot N r_{i t-2}, G i n i_{i} \cdot N r_{i t-3}, X_{i t-2}, X_{i t-3}\right]
$$

In order for the difference GMM and system GMM to be appropriate estimation methods, no serial correlation should exist in the first-differenced errors at orders 2 and above. A Sargan test constructs p-values such that the null hypothesis of $\operatorname{Cov}\left(\Delta \varepsilon_{i t}, \Delta \varepsilon_{i t-\tau}\right)=0$ for $\tau=1,2,3$, is rejected at 5 percent level if $p<0.05$. If $\varepsilon_{i t}$ are not serially correlated, then I expect to reject the null hypothesis at order 1 , but not at higher orders.

same time, under the crucial assumption of no serial correlation of the error terms (which I test later on), $\Delta \varepsilon_{i t}$ is uncorrelated with $\Delta \log G D P_{i t-\tau}$ for $\tau \geq 2$ so that additional lags are valid to be used as instruments in an instrumental variable (IV) estimation.

${ }^{33}$ This exact identification problem is not the case in a system GMM estimation since the number of instruments that are generated is more than the number of endogenous variables. Thus, the Blundell-Bond estimator uses one lag for all the predetermined and endogenous variables. 
Table 5: Test of Autocorrelation in the Error Terms

\begin{tabular}{|c|c|c|c|c|c|c|c|c|}
\hline \multirow[b]{2}{*}{ Orders } & \multicolumn{2}{|c|}{$\begin{array}{c}\text { (Current Natural Resource } \\
\text { Rents) }\end{array}$} & \multicolumn{2}{|c|}{$\begin{array}{c}\text { (Lagged Natural Resource } \\
\text { Rents) }\end{array}$} & \multicolumn{2}{|c|}{$\begin{array}{c}\text { (Current Natural Resource } \\
\text { Rents) }\end{array}$} & \multicolumn{2}{|c|}{$\begin{array}{c}\text { (Lagged Natural Resource } \\
\text { Rents) }\end{array}$} \\
\hline & $\mathrm{z}$ & P-value & $\mathrm{z}$ & P-value & $\mathrm{z}$ & P-value & $\mathrm{z}$ & P-value \\
\hline \multicolumn{9}{|c|}{ Panel A - Arellano-Bond Estimation } \\
\hline 1 & -3.54 & 0.000 & -3.37 & 0.001 & -3.38 & 0.001 & -3.10 & 0.002 \\
\hline 2 & -0.55 & 0.580 & -0.85 & 0.393 & 0.31 & 0.758 & -0.48 & 0.634 \\
\hline 3 & 0.39 & 0.695 & 0.26 & 0.793 & -0.18 & 0.854 & -0.01 & 0.994 \\
\hline \multicolumn{9}{|c|}{ Panel B - Arellano-Bond Estimation Using the Residuals } \\
\hline 1 & -3.58 & 0.000 & -3.02 & 0.003 & -3.15 & 0.002 & -3.12 & 0.002 \\
\hline 2 & -0.32 & 0.747 & -0.68 & 0.496 & -0.33 & 0.739 & -0.31 & 0.756 \\
\hline 3 & 0.35 & 0.728 & 0.17 & 0.867 & 0.06 & 0.953 & -0.03 & 0.979 \\
\hline \multicolumn{9}{|c|}{ Panel C-Blundell-Bond } \\
\hline 1 & -3.85 & 0.000 & -3.75 & 0.000 & -3.38 & 0.001 & -3.31 & 0.001 \\
\hline 2 & -0.25 & 0.801 & -0.34 & 0.737 & 0.19 & 0.851 & 0.14 & 0.892 \\
\hline 3 & 0.28 & 0.777 & 0.19 & 0.848 & -0.13 & 0.896 & -0.27 & 0.784 \\
\hline \multicolumn{9}{|c|}{ Panel D - Blundell-Bond Estimation Using the Residuals } \\
\hline 1 & -3.81 & 0.000 & -3.72 & 0.000 & -3.45 & 0.001 & -3.34 & 0.001 \\
\hline 2 & -0.17 & 0.865 & -0.36 & 0.719 & 0.32 & 0.751 & 0.16 & 0.871 \\
\hline 3 & 0.32 & 0.752 & 0.21 & 0.836 & -0.14 & 0.892 & -0.26 & 0.798 \\
\hline $\begin{array}{l}\text { Communis } \\
\text { Countries } \\
\text { Excluded }\end{array}$ & \multicolumn{2}{|c|}{$\mathrm{NO}$} & \multicolumn{2}{|c|}{ NO } & \multicolumn{2}{|c|}{ YES } & \multicolumn{2}{|c|}{ YES } \\
\hline
\end{tabular}

Notes: There is no autocorrelation in the error terms at orders 2 and above in all of the regressions. Thus using two further lags as instruments is appropriate.

As shown in table 5 the p-values indicate that we fail to reject the null hypothesis at orders 2 and above. Thus, there is no serial correlation in the error terms and two and three period lagged terms are valid instruments.

Table 6 reports the results of estimating equation (49) using the Arellano-Bond method. ${ }^{34}$ In columns (1) and (3) the GMM estimation is performed on all variables including current natural resource rents. In columns (2) and (4) it is replaced by lagged natural resources. There are four communist countries in my data set. Although low income inequality is a matter of ideology in communist countries, the same cannot be said for accurate reporting

\footnotetext{
${ }^{34} \mathrm{My}$ results are robust to the use of additional lags as instruments. These variations are contained in section 3.2.3.
} 
Table 6: Arellano-Bond Estimation

\begin{tabular}{|c|c|c|c|c|}
\hline Variables & $\begin{array}{c}(1) \\
\text { (Current Natural } \\
\text { Resource Rents) }\end{array}$ & $\begin{array}{c}(2) \\
\text { (Lagged Natural } \\
\text { Resource Rents) }\end{array}$ & $\begin{array}{c}\text { (3) } \\
\text { (Current Natural } \\
\text { Resource Rents) } \\
\end{array}$ & $\begin{array}{c}(4) \\
\text { (Lagged Natural } \\
\text { Resource Rents) }\end{array}$ \\
\hline Log of GDP per capita (lagged one period) & $\begin{array}{l}-0.360 \\
(0.455)\end{array}$ & $\begin{array}{c}0.141 \\
(0.463)\end{array}$ & $\begin{array}{l}-0.077 \\
(0.378)\end{array}$ & $\begin{array}{l}-0.060 \\
(0.229)\end{array}$ \\
\hline Log of GDP per capita (lagged one period) squared & $\begin{array}{c}0.026 \\
(0.031)\end{array}$ & $\begin{array}{l}-0.008 \\
(0.031)\end{array}$ & $\begin{array}{c}0.006 \\
(0.026)\end{array}$ & $\begin{array}{c}0.006 \\
(0.016)\end{array}$ \\
\hline Natural resource rents & $\begin{array}{l}-2.268 \\
(3.153)\end{array}$ & & $\begin{array}{l}1.968 \\
(1.186)\end{array}$ & \\
\hline Natural resource rents $\times$ Gini coefficient & $\begin{array}{c}7.583 \\
(7.250)\end{array}$ & & $\begin{array}{l}-3.695 \\
(2.822)\end{array}$ & \\
\hline Inflation & $\begin{array}{l}-0.002 \\
(0.001)\end{array}$ & $\begin{array}{c}-0.002 * \\
(0.001)\end{array}$ & $\begin{array}{l}-0.002 \\
(0.001)\end{array}$ & $\begin{array}{c}-0.002 * * \\
(0.001)\end{array}$ \\
\hline Institutional quality & $\begin{array}{c}0.350 \\
(0.355)\end{array}$ & $\begin{array}{l}-0.403 \\
(0.451)\end{array}$ & $\begin{array}{l}0.036 \\
(0.167)\end{array}$ & $\begin{array}{l}-0.135 \\
(0.194)\end{array}$ \\
\hline Natural resource rents $\times$ Institutional quality & $\begin{array}{l}-1.845 \\
(1.517)\end{array}$ & & $\begin{array}{l}-0.169 \\
(1.423)\end{array}$ & \\
\hline Growth rate of terms of trade & $\begin{array}{c}0.007 \\
(0.014)\end{array}$ & $\begin{array}{c}0.028 * * \\
(0.012)\end{array}$ & $\begin{array}{c}0.008 \\
(0.011)\end{array}$ & $\begin{array}{c}0.027^{* *} \\
(0.010)\end{array}$ \\
\hline Log of fertility rate & $\begin{array}{c}0.149 \\
(0.278)\end{array}$ & $\begin{array}{l}-0.564 \\
(0.397)\end{array}$ & $\begin{array}{l}-0.139 \\
(0.233)\end{array}$ & $\begin{array}{l}-0.404 \\
(0.336)\end{array}$ \\
\hline Government consumption & $\begin{array}{l}0.125 \\
(0.385)\end{array}$ & $\begin{array}{l}-0.152 \\
(0.263)\end{array}$ & $\begin{array}{l}-0.149 \\
(0.361)\end{array}$ & $\begin{array}{l}-0.085 \\
(0.143)\end{array}$ \\
\hline Investments & $\begin{array}{c}0.180 \\
(0.194)\end{array}$ & $\begin{array}{c}0.244 \\
(0.235)\end{array}$ & $\begin{array}{l}0.205 \\
(0.172)\end{array}$ & $\begin{array}{c}0.157 \\
(0.192)\end{array}$ \\
\hline Natural resource rents (lagged one period) & & $\begin{array}{l}2.570^{*} \\
(1.488)\end{array}$ & & $\begin{array}{c}1.933 * * * \\
(0.609)\end{array}$ \\
\hline $\begin{array}{l}\text { Natural resource rents (lagged one period) } \times \text { Gini } \\
\text { coefficient }\end{array}$ & & $\begin{array}{l}-7.096 \\
(4.344)\end{array}$ & & $\begin{array}{c}-4.358 * * * \\
(1.498)\end{array}$ \\
\hline $\begin{array}{l}\text { Natural resource rents (lagged one period) } \times \\
\text { Institutional quality }\end{array}$ & & $\begin{array}{l}2.904 \\
(2.369)\end{array}$ & & $\begin{array}{l}1.388 \\
(1.078)\end{array}$ \\
\hline Hansen test & 0.068 & 0.863 & 0.072 & 0.854 \\
\hline Number of observations & 774 & 774 & 730 & 730 \\
\hline Number of countries & 61 & 61 & 57 & 57 \\
\hline Communist Countries Excluded & $\mathrm{NO}$ & $\mathrm{NO}$ & YES & YES \\
\hline
\end{tabular}

Notes: Dependant variable is real GDP per capita growth (annual percent) measured by $\left(\operatorname{logGDP} t-\operatorname{logGDP}_{t-1}\right)$. Year fixed effects are included in all of the estimations. Arellano-Bond estimation is by two-step GMM procedure. All variables, except growth of terms of trade and the year effects are instrumented with a maximum of 1 further lag for the lagged GDP and 2 further lags for the rest of the variables. The figures reported for the Hansen overidentification test, are p-values for the null hypothesis of valid instruments with $\chi^{2}(6)$. Total number of instruments is 33 . Robust standard errors are reported in parentheses.

*** Significant at the 1 percent level. ** Significant at the 5 percent level. * Significant at the 10 percent level.

of economic statistics. I, therefore, create a restricted sample and exempt the communist countries from my analysis in columns (3) and (4) to test if the results are affected by the presence of these countries. ${ }^{35}$ The results presented in this table suggest that when lagged

\footnotetext{
${ }^{35}$ Although not significant, the coefficient of natural resource rents and its interaction term have the wrong sign in column (1). I note, however, that the Hansen test p-value is low for the instruments in column (1) so that this result may not be directly attributable to the data from the communist countries. A weak Hansen test p-value also plagues the results in column (1) of table 8. When I use the Blundell-Bond estimators
} 
natural resource rents are taken into account, the resource rents variable and its interaction with inequality have the expected signs. The interaction of lagged resource rents and the Gini coefficient has a significant negative impact on GDP growth when communist countries are excluded from the sample. From the results in column (4) natural resource rents will only increase the growth rate of GDP if the Gini is less than 0.44. In particular, from equation (15) we have that $\frac{\partial \Delta \log G D P_{i t}}{\partial N r_{i t}}=\beta_{2}+\beta_{3}\left(G i n i_{i}\right)$ which implies a critical gini coefficient of $\frac{-\beta_{2}}{\beta_{3}}$, which in the case of column (4) is $1.933 / 4.358$.

One concern with my results is that although the estimated coefficient for lagged GDP is negative, it is insignificant so that conditional convergence appears to be absent in my results. It should be noted, however, that conditional convergence is more of a long term phenomenon than an annual one.

Table 7: Correlation Matrix

\begin{tabular}{|c|c|c|c|c|c|c|c|c|c|c|c|}
\hline & $\begin{array}{l}\text { Real GDP } \\
\text { per capita } \\
\text { growth }\end{array}$ & $\begin{array}{c}\text { Gini } \\
\text { coefficient }\end{array}$ & $\begin{array}{c}\text { Natural } \\
\text { resource } \\
\text { rents }\end{array}$ & $\begin{array}{c}\text { Institutional } \\
\text { quality }\end{array}$ & $\begin{array}{c}\text { Log of } \\
\text { fertility rate }\end{array}$ & $\begin{array}{l}\text { Government } \\
\text { consumption }\end{array}$ & Inflation & Investments & $\begin{array}{l}\text { Growth rate } \\
\text { of terms of } \\
\text { trade }\end{array}$ & $\begin{array}{l}\text { Lagged log } \\
\text { of GDP per } \\
\text { capita }\end{array}$ & $\begin{array}{c}\text { Lagged log } \\
\text { of GDP per } \\
\text { capita } \\
\text { squared } \\
\end{array}$ \\
\hline $\begin{array}{l}\text { Real GDP per capita } \\
\text { growth }\end{array}$ & 1.000 & & & & & & & & & & \\
\hline Gini coefficient & -0.096 & 1.000 & & & & & & & & & \\
\hline Natural resource rents & -0.140 & -0.055 & 1.000 & & & & & & & & \\
\hline Institutional quality & 0.254 & 0.159 & -0.174 & 1.000 & & & & & & & \\
\hline Log of fertility rate & -0.293 & -0.091 & 0.239 & -0.566 & 1.000 & & & & & & \\
\hline $\begin{array}{l}\text { Government } \\
\text { consumption }\end{array}$ & -0.222 & 0.232 & 0.077 & 0.068 & 0.177 & 1.000 & & & & & \\
\hline Inflation & -0.173 & 0.088 & 0.016 & -0.070 & -0.010 & 0.121 & 1.000 & & & & \\
\hline Investments & 0.299 & -0.181 & 0.088 & 0.216 & -0.322 & 0.098 & -0.012 & 1.000 & & & \\
\hline $\begin{array}{l}\text { Growth rate of terms } \\
\text { of trade }\end{array}$ & 0.117 & 0.021 & -0.113 & 0.103 & -0.076 & -0.015 & 0.022 & -0.052 & 1.000 & & \\
\hline $\begin{array}{l}\text { Lagged log of GDP } \\
\text { per capita }\end{array}$ & -0.000 & 0.412 & 0.000 & 0.481 & -0.643 & 0.136 & 0.022 & 0.194 & -0.007 & 1.000 & \\
\hline $\begin{array}{l}\text { Lagged log of GDP } \\
\text { per capita squared }\end{array}$ & 0.002 & 0.389 & 0.005 & 0.499 & -0.642 & 0.128 & 0.016 & 0.185 & -0.010 & 0.995 & 1.000 \\
\hline
\end{tabular}

Most of the panel studies which have found significant growth convergence (see Barro, 2000, Banerjee and Duflo, 2003, and the literature cited by them) have considered 5-year intervals for their sample, whereas in my analysis I am interested in year-on-year changes to take to control for weak instruments, the Hansen test provides strong p-values for all 8 formulations and the coefficient on natural resources and its interaction have the expected sign in all 8 columns of tables 3 and 4 . 
into account the annual fluctuations of natural resource rents. Still, my estimated coefficient has the correct sign, implying that conditional convergence may also have appeared in my analysis if I had considered longer time intervals.

Table 8: Arellano-Bond Estimation; Robustness Check Using Residuals

\begin{tabular}{|c|c|c|c|c|}
\hline Variables & $\begin{array}{c}(1) \\
\text { (Current Natural } \\
\text { Resource Rents) } \\
\end{array}$ & $\begin{array}{c}(2) \\
\text { (Lagged Natural } \\
\text { Resource Rents) } \\
\end{array}$ & $\begin{array}{c}\text { (3) } \\
\text { (Current Natural } \\
\text { Resource Rents) } \\
\end{array}$ & $\begin{array}{c}(4) \\
\text { (Lagged Natural } \\
\text { Resource Rents) } \\
\end{array}$ \\
\hline Log of GDP per capita (lagged one period) & $\begin{array}{l}-0.196 \\
(0.355)\end{array}$ & $\begin{array}{c}0.099 \\
(0.423)\end{array}$ & $\begin{array}{l}-0.504 \\
(0.762)\end{array}$ & $\begin{array}{l}-0.074 \\
(0.224)\end{array}$ \\
\hline Log of GDP per capita (lagged one period) squared & $\begin{array}{c}0.014 \\
(0.024)\end{array}$ & $\begin{array}{c}-0.005 \\
(0.029)\end{array}$ & $\begin{array}{c}0.035 \\
(0.052)\end{array}$ & $\begin{array}{c}0.006 \\
(0.015)\end{array}$ \\
\hline Natural resource rents & $\begin{array}{c}0.776 \\
(0.594)\end{array}$ & & $\begin{array}{c}0.861 \\
(0.694)\end{array}$ & \\
\hline Natural resource rents $\times$ Residuals & $\begin{array}{l}1.088 \\
(9.762)\end{array}$ & & $\begin{array}{l}-4.617 \\
(4.021)\end{array}$ & \\
\hline Inflation & $\begin{array}{c}-0.002 * * \\
(0.001)\end{array}$ & $\begin{array}{l}-0.002 * \\
(0.001)\end{array}$ & $\begin{array}{l}-0.001 \\
(0.001)\end{array}$ & $\begin{array}{c}-0.002 * * \\
(0.001)\end{array}$ \\
\hline Institutional quality & $\begin{array}{c}0.208 \\
(0.296)\end{array}$ & $\begin{array}{l}-0.371 \\
(0.429)\end{array}$ & $\begin{array}{c}0.216 \\
(0.301)\end{array}$ & $\begin{array}{l}-0.126 \\
(0.191)\end{array}$ \\
\hline Natural resource rents $\times$ Institutional quality & $\begin{array}{l}-0.589 \\
(1.481)\end{array}$ & & $\begin{array}{l}-2.132 \\
(2.163)\end{array}$ & \\
\hline Growth rate of terms of trade & $\begin{array}{c}0.008 \\
(0.014)\end{array}$ & $\begin{array}{c}0.027^{* *} * \\
(0.012)\end{array}$ & $\begin{array}{c}0.019 \\
(0.016)\end{array}$ & $\begin{array}{c}0.026^{* * *} \\
(0.010)\end{array}$ \\
\hline Log of fertility rate & $\begin{array}{c}0.038 \\
(0.276)\end{array}$ & $\begin{array}{l}-0.561 \\
(0.388)\end{array}$ & $\begin{array}{l}-0.186 \\
(0.320)\end{array}$ & $\begin{array}{l}-0.409 \\
(0.333)\end{array}$ \\
\hline Government consumption & $\begin{array}{c}0.019 \\
(0.156)\end{array}$ & $\begin{array}{l}-0.144 \\
(0.238)\end{array}$ & $\begin{array}{l}-0.113 \\
(0.393)\end{array}$ & $\begin{array}{l}-0.081 \\
(0.138)\end{array}$ \\
\hline Investments & $\begin{array}{c}0.221 \\
(0.198)\end{array}$ & $\begin{array}{c}0.233 \\
(0.228)\end{array}$ & $\begin{array}{c}0.160 \\
(0.182)\end{array}$ & $\begin{array}{c}0.147 \\
(0.191)\end{array}$ \\
\hline Natural resource rents (lagged one period) & & $\begin{array}{l}-0.170 \\
(0.642)\end{array}$ & & $\begin{array}{c}0.243 \\
(0.357)\end{array}$ \\
\hline Natural resource rents (lagged one period) $\times$ Residuals & & $\begin{array}{l}-6.868^{*} \\
(4.098)\end{array}$ & & $\begin{array}{c}-4.249 * * * \\
(1.425)\end{array}$ \\
\hline $\begin{array}{l}\text { Natural resource rents (lagged one period) } \times \\
\text { Institutional quality }\end{array}$ & & $\begin{array}{c}1.947 \\
(1.991)\end{array}$ & & $\begin{array}{c}0.819 \\
(0.969)\end{array}$ \\
\hline Hansen test & 0.037 & 0.862 & 0.156 & 0.872 \\
\hline Number of observations & 774 & 774 & 730 & 730 \\
\hline Number of countries & 61 & 61 & 57 & 57 \\
\hline Communist Countries Excluded & $\mathrm{NO}$ & $\mathrm{NO}$ & YES & YES \\
\hline \multicolumn{5}{|c|}{$\begin{array}{l}\text { Notes: Dependant variable is real GDP per capita growth (annual percent) measured by }\left(\log \mathrm{GDP}_{t}-\operatorname{logGDP} \mathrm{t}-1\right) \text {. In all } \\
\text { estimations, the measure of inequality (Gini) is replaced by the residuals of regressing Gini on Institutional quality. Year fixed } \\
\text { effects are included in all of the estimations. Arellano-Bond estimation is by two-step GMM procedure. All variables, except } \\
\text { growth of terms of trade and the year effects are instrumented with a maximum of } 1 \text { further lag for the lagged GDP and } 2 \\
\text { further lags for the rest of the variables. The figures reported for the Hansen overidentification test, are p-values for the null } \\
\text { hypothesis of valid instruments with } X^{2}(6) \text {. Total number of instruments is 33. Robust standard errors are reported in } \\
\text { parentheses. }\end{array}$} \\
\hline
\end{tabular}

A further concern is that the Gini coefficients and institutional quality could be correlated, in which case the Gini coefficients would capture the effects of institutional quality on growth 
rather than my postulated distributional effects. Although the correlation matrix in table 7 shows a negligible linear correlation between these two variables, I would like to make sure that my results are not driven by any (either linear or non-linear) correlation between inequality and institutional quality.

In order to remove such a possible multicollinearity problem, and check whether my results remain robust, I adapt the following procedure. I begin by regressing the Gini coefficient on institutional quality and the quadratic institutional quality term, then retrieve the residuals from this regression. I next use these residuals instead of the Gini coefficient so that I have a measure of income inequality purged from institutional quality.

Table 8 presents the results of the same regressions as in table 6 with these purged Gini coefficients. My previous findings improve after this adjustment: in the non-restricted sample, I also find a significant estimated coefficient on the interaction term in the lagged regression (in column 2).

\subsubsection{System GMM estimation}

Although the Arellano-Bond estimator is dynamically consistent, it might suffer from finite sample biases in the presence of weak instruments. For example, lagged levels of the series may be weakly correlated with the subsequent first differences if there is either a unit root problem in the series or if the variance of the individual effects $\left(\delta_{i}\right)$ increases relative to variance of the error terms $\left(\varepsilon_{i t}\right)$. Although, as shown in the unit root test in table A6 in the appendix, there is no non-stationarity problem in my panel, I cannot be certain that the lagged values are uniformly strong instruments. I, therefore, also perform a system GMM estimation introduced by Arellano and Bover (1995) and Blundell and Bond (1998) to examine whether my results are robust in the presence of these possible drawbacks. In particular, the Blundell-Bond system GMM estimator combines the set of first-differenced equations and lagged level instruments (as used in the Arellano-Bond difference GMM estimator), with an extra set of level equations and immediate lagged first differences as instruments. ${ }^{36}$

\footnotetext{
${ }^{36}$ See Blundell and Bond (1998) for the calculation of the system GMM estimator.
} 
Table 9: Blundell-Bond Estimation

\begin{tabular}{|c|c|c|c|c|}
\hline Variables & $\begin{array}{c}(1) \\
\text { (Current Natural } \\
\text { Resource Rents) } \\
\end{array}$ & $\begin{array}{c}(2) \\
\text { (Lagged Natural } \\
\text { Resource Rents) } \\
\end{array}$ & $\begin{array}{c}\text { (3) } \\
\text { (Current Natural } \\
\text { Resource Rents) } \\
\end{array}$ & $\begin{array}{c}(4) \\
\text { (Lagged Natural } \\
\text { Resource Rents) }\end{array}$ \\
\hline Log of GDP per capita (lagged one period) & $\begin{array}{l}-0.287 \\
(0.182)\end{array}$ & $\begin{array}{l}-0.129 \\
(0.122)\end{array}$ & $\begin{array}{l}-0.338^{*} \\
(0.171)\end{array}$ & $\begin{array}{l}-0.140 \\
(0.152)\end{array}$ \\
\hline Log of GDP per capita (lagged one period) squared & $\begin{array}{c}0.020 \\
(0.013)\end{array}$ & $\begin{array}{c}0.009 \\
(0.009)\end{array}$ & $\begin{array}{l}0.023 * \\
(0.012)\end{array}$ & $\begin{array}{c}0.009 \\
(0.011)\end{array}$ \\
\hline Natural resource rents & $\begin{array}{c}1.471 * * \\
(0.572)\end{array}$ & & $\begin{array}{c}1.372 * * * \\
(0.390)\end{array}$ & \\
\hline Natural resource rents $\times$ Gini coefficient & $\begin{array}{l}-1.971 \\
(1.208)\end{array}$ & & $\begin{array}{c}-2.081^{* *} \\
(1.012)\end{array}$ & \\
\hline Inflation & $\begin{array}{l}-0.002^{*} \\
(0.001)\end{array}$ & $\begin{array}{c}-0.001 \\
(0.001)\end{array}$ & $\begin{array}{l}-0.002 \\
(0.001)\end{array}$ & $\begin{array}{l}-0.001 \\
(0.001)\end{array}$ \\
\hline Institutional quality & $\begin{array}{c}0.113 \\
(0.083)\end{array}$ & $\begin{array}{c}0.097 \\
(0.083)\end{array}$ & $\begin{array}{c}0.045 \\
(0.099)\end{array}$ & $\begin{array}{c}0.076 \\
(0.098)\end{array}$ \\
\hline Natural resource rents $\times$ Institutional quality & $\begin{array}{c}-1.031 * * \\
(0.430)\end{array}$ & & $\begin{array}{l}-0.871 * \\
(0.517)\end{array}$ & \\
\hline Growth rate of terms of trade & $\begin{array}{c}0.018 \\
(0.011)\end{array}$ & $\begin{array}{c}0.020 * * \\
(0.009)\end{array}$ & $\begin{array}{c}0.023 * * \\
(0.011)\end{array}$ & $\begin{array}{c}0.019 * * \\
(0.009)\end{array}$ \\
\hline Log of fertility rate & $\begin{array}{c}0.032 \\
(0.044)\end{array}$ & $\begin{array}{c}0.011 \\
(0.033)\end{array}$ & $\begin{array}{c}0.028 \\
(0.040)\end{array}$ & $\begin{array}{l}0.026 \\
(0.038)\end{array}$ \\
\hline Government consumption & $\begin{array}{c}0.083 \\
(0.277)\end{array}$ & $\begin{array}{c}0.013 \\
(0.156)\end{array}$ & $\begin{array}{c}0.052 \\
(0.166)\end{array}$ & $\begin{array}{c}0.114 \\
(0.147)\end{array}$ \\
\hline Investments & $\begin{array}{c}0.206^{* *} \\
(0.103)\end{array}$ & $\begin{array}{c}0.184 * * \\
(0.089)\end{array}$ & $\begin{array}{l}0.185^{*} \\
(0.097)\end{array}$ & $\begin{array}{l}0.141 * \\
(0.077)\end{array}$ \\
\hline Natural resource rents (lagged one period) & & $\begin{array}{l}0.637^{*} \\
(0.371)\end{array}$ & & $\begin{array}{c}0.618 \\
(0.391)\end{array}$ \\
\hline $\begin{array}{l}\text { Natural resource rents (lagged one period) } \times \text { Gini } \\
\text { coefficient }\end{array}$ & & $\begin{array}{c}-0.928 * * \\
(0390)\end{array}$ & & $\begin{array}{l}-1.211 * * * \\
(0.440)\end{array}$ \\
\hline $\begin{array}{l}\text { Natural resource rents (lagged one period) } \times \\
\text { Institutional quality }\end{array}$ & & $\begin{array}{l}-0.302 \\
(0.491)\end{array}$ & & $\begin{array}{l}-0.069 \\
(0.542)\end{array}$ \\
\hline Hansen test & 0.487 & 0.334 & 0.416 & 0.201 \\
\hline Number of observations & 836 & 836 & 788 & 788 \\
\hline Number of countries & 61 & 61 & 57 & 57 \\
\hline Communist Countries Excluded & NO & NO & YES & YES \\
\hline
\end{tabular}

The validity of these instruments are satisfied by the reported p-values of the Hansen overidentification test. In each case the Hansen test p-value is higher than 5 percent and ranges from around $20 \%$ to $80 \%$. I report the results of the Blundell-Bond estimation below.

The results of the Blundell-Bond estimations are reported in table 9 and the corresponding results of the robustness check where I use the residuals of the regression of the Gini on institutional quality and its square are presented in table 10. 
Table 10: Blundell-Bond Estimation; Robustness Check Using Residuals

\begin{tabular}{|c|c|c|c|c|}
\hline Variables & $\begin{array}{c}\text { (1) } \\
\text { (Current Natural } \\
\text { Resource Rents) } \\
\end{array}$ & $\begin{array}{c}\text { (2) } \\
\text { (Lagged Natural } \\
\text { Resource Rents) } \\
\end{array}$ & $\begin{array}{c}\text { (3) } \\
\text { (Current Natural } \\
\text { Resource Rents) } \\
\end{array}$ & $\begin{array}{c}(4) \\
\text { (Lagged Natural } \\
\text { Resource Rents) } \\
\end{array}$ \\
\hline Log of GDP per capita (lagged one period) & $\begin{array}{l}-0.095 \\
(0.251)\end{array}$ & $\begin{array}{l}-0.114 \\
(0.121)\end{array}$ & $\begin{array}{l}-0.156 \\
(0.233)\end{array}$ & $\begin{array}{l}-0.126 \\
(0.147)\end{array}$ \\
\hline Log of GDP per capita (lagged one period) squared & $\begin{array}{c}0.007 \\
(0.018)\end{array}$ & $\begin{array}{c}0.008 \\
(0.009)\end{array}$ & $\begin{array}{c}0.011 \\
(0.016)\end{array}$ & $\begin{array}{c}0.008 \\
(0.010)\end{array}$ \\
\hline Natural resource rents & $\begin{array}{c}0.490 \\
(0.300)\end{array}$ & & $\begin{array}{l}0.498^{*} \\
(0.264)\end{array}$ & \\
\hline Natural resource rents $\times$ Residuals & $\begin{array}{l}-1.412 \\
(1.262)\end{array}$ & & $\begin{array}{l}-2.568^{*} \\
(1.535)\end{array}$ & \\
\hline Inflation & $\begin{array}{l}-0.001 \\
(0.001)\end{array}$ & $\begin{array}{l}-0.001 \\
(0.001)\end{array}$ & $\begin{array}{l}-0.002 \\
(0.001)\end{array}$ & $\begin{array}{l}-0.001 \\
(0.001)\end{array}$ \\
\hline Institutional quality & $\begin{array}{c}0.143 \\
(0.092)\end{array}$ & $\begin{array}{c}0.109 \\
(0.084)\end{array}$ & $\begin{array}{c}0.079 \\
(0.108)\end{array}$ & $\begin{array}{c}0.082 \\
(0.090)\end{array}$ \\
\hline Natural resource rents $\times$ Institutional quality & $\begin{array}{l}-0.656 \\
(0.633)\end{array}$ & & $\begin{array}{l}-0.777 \\
(0.570)\end{array}$ & \\
\hline Growth rate of terms of trade & $\begin{array}{c}0.025 * * \\
(0.011)\end{array}$ & $\begin{array}{c}0.020 * * \\
(0.009)\end{array}$ & $\begin{array}{c}0.025^{* *} \\
(0.010)\end{array}$ & $\begin{array}{c}0.021 * * \\
(0.009)\end{array}$ \\
\hline Log of fertility rate & $\begin{array}{l}-0.012 \\
(0.034)\end{array}$ & $\begin{array}{c}0.005 \\
(0.035)\end{array}$ & $\begin{array}{c}0.010 \\
(0.049)\end{array}$ & $\begin{array}{c}0.020 \\
(0.037)\end{array}$ \\
\hline Government consumption & $\begin{array}{l}-0.015 \\
(0.187)\end{array}$ & $\begin{array}{l}-0.034 \\
(0.157)\end{array}$ & $\begin{array}{c}0.015 \\
(0.152)\end{array}$ & $\begin{array}{c}0.086 \\
(0.132)\end{array}$ \\
\hline Investments & $\begin{array}{c}0.179 * * \\
(0.073)\end{array}$ & $\begin{array}{c}0.177 * * \\
(0.085)\end{array}$ & $\begin{array}{c}0.176^{* *} \\
(0.072)\end{array}$ & $\begin{array}{l}0.135^{*} \\
(0.071)\end{array}$ \\
\hline Natural resource rents (lagged one period) & & $\begin{array}{c}0.315 \\
(0.247)\end{array}$ & & $\begin{array}{c}0.177 \\
(0.232)\end{array}$ \\
\hline Natural resource rents (lagged one period) $\times$ Residuals & & $\begin{array}{l}-1.008^{*} \\
(0.520)\end{array}$ & & $\begin{array}{c}-1.381 * * * \\
(0.513)\end{array}$ \\
\hline $\begin{array}{l}\text { Natural resource rents (lagged one period) } \times \\
\text { Institutional quality }\end{array}$ & & $\begin{array}{l}-0.441 \\
(0.491)\end{array}$ & & $\begin{array}{l}-0.238 \\
(0.501)\end{array}$ \\
\hline Hansen test & 0.393 & 0.417 & 0.537 & 0.249 \\
\hline Number of observations & 836 & 836 & 788 & 788 \\
\hline Number of countries & 61 & 61 & 57 & 57 \\
\hline Communist Countries Excluded & $\mathrm{NO}$ & NO & YES & YES \\
\hline
\end{tabular}

Since the Blundell-Bond estimator generates more than one instrument for each variable there is no problem of exact identification and I use only one lag for each variable. Still, I report the results of using additional lags in section 3.2.3 and I note here that my results are robust to the inclusion of these additional lags.

As we see in tables 9 and 10 the results from the Blundell-Bond estimation procedure establish the robustness of my results in tables 6 and 8 and improve on those results in many 
respects. For example, in table 9 natural resource rents is found to increase growth if the Gini coefficient is below a critical level in all four specifications. Furthermore, I find that investment, as expected, has a significant positive effect on growth. I also find some significant evidence of GDP growth convergence, however, as mentioned in the previous section I should not expect to find strong evidence of convergence when looking at annual changes. Most importantly, my coefficient of interest on the interaction term between the Gini coefficient (or the residuals) and natural resource rents (or its lagged value) is still negative and significant. The Blundell-Bond estimated coefficient on this interaction term, however, is smaller than that in the Arellano-Bond estimation, which suggests that in my case the difference GMM estimator is biased upwards. Although the Arellano-Bond estimators are consistent, and they provide results that support my theory, by tackling the issue of weak instruments Blundell-Bond estimation provides more reliable results for my analysis and ones that are even more supportive of my model.

\subsubsection{Additional Robustness Checks}

As indicated in the previous section, Arellano and Bond proposed first differencing the level equation to purge out the individual effects, and simultaneously instrumenting the differenced variables using a panel GMM estimator to improve the efficiency of the estimation. In this case, the instruments are the deeper lags (starting from $t-2$ ) of each of the endogenous and predetermined variables assuming that the errors are serially uncorrelated. ${ }^{37}$

Although the Arellano-Bond estimator is consistent in a dynamic panel, there are two issues with this instrumentation procedure. First, lagged variables are usually considered as weak instruments in explaining the endogenous variables. This weak correlation can ultimately result in finite sample biases when I use the difference GMM approach (see Blundell and Bond (1998)). To overcome this issue I also estimate my model using the system GMM approach that was introduced by Blundell and Bond (1998). According to Bond, Hoeffler, and Temple (2001) this system GMM approach reduces the finite sample bias in dynamic panel growth

\footnotetext{
${ }^{37}$ This assumption is tested by a test of autocorrelation in the error terms. The results presented in table 5 suggest no serial correlation at order 2 and above.
} 
Table 11: Arellano-Bond Estimation (Two Lags)

\begin{tabular}{|c|c|c|c|c|}
\hline Variables & $\begin{array}{c}(1) \\
\text { (Current Natural } \\
\text { Resource Rents) } \\
\end{array}$ & $\begin{array}{c}(2) \\
\text { (Lagged Natural } \\
\text { Resource Rents) } \\
\end{array}$ & $\begin{array}{c}\text { (3) } \\
\text { (Current Natural } \\
\text { Resource Rents) } \\
\end{array}$ & $\begin{array}{c}(4) \\
\text { (Lagged Natural } \\
\text { Resource Rents) } \\
\end{array}$ \\
\hline Log of GDP per capita (lagged one period) & $\begin{array}{l}-0.402 \\
(0.511)\end{array}$ & $\begin{array}{l}-0.079 \\
(0.252)\end{array}$ & $\begin{array}{l}-0.121 \\
(0.375)\end{array}$ & $\begin{array}{l}-0.161 \\
(0.233)\end{array}$ \\
\hline Log of GDP per capita (lagged one period) squared & $\begin{array}{c}0.029 \\
(0.035)\end{array}$ & $\begin{array}{c}0.007 \\
(0.017)\end{array}$ & $\begin{array}{c}0.009 \\
(0.026)\end{array}$ & $\begin{array}{c}0.013 \\
(0.016)\end{array}$ \\
\hline Natural resource rents & $\begin{array}{l}-1.293 \\
(1.889)\end{array}$ & & $\begin{array}{c}1.874 \\
(1.216)\end{array}$ & \\
\hline Natural resource rents $\times$ Gini coefficient & $\begin{array}{c}5.130 \\
(4.452)\end{array}$ & & $\begin{array}{l}-3.424 \\
(2.681)\end{array}$ & \\
\hline Inflation & $\begin{array}{l}-0.002 \\
(0.001)\end{array}$ & $\begin{array}{l}-0.002 * \\
(0.001)\end{array}$ & $\begin{array}{l}-0.002 \\
(0.001)\end{array}$ & $\begin{array}{l}-0.001 \\
(0.001)\end{array}$ \\
\hline Institutional quality & $\begin{array}{c}0.278 \\
(0.320)\end{array}$ & $\begin{array}{l}-0.084 \\
(0.223)\end{array}$ & $\begin{array}{c}0.039 \\
(0.153)\end{array}$ & $\begin{array}{l}-0.104 \\
(0.171)\end{array}$ \\
\hline Natural resource rents $\times$ Institutional quality & $\begin{array}{l}-1.540 \\
(1.507)\end{array}$ & & $\begin{array}{l}-0.274 \\
(1.265)\end{array}$ & \\
\hline Growth rate of terms of trade & $\begin{array}{c}0.009 \\
(0.014)\end{array}$ & $\begin{array}{c}0.028 * * * \\
(0.009)\end{array}$ & $\begin{array}{c}0.007 \\
(0.013)\end{array}$ & $\begin{array}{c}0.025^{* *} \\
(0.010)\end{array}$ \\
\hline Log of fertility rate & $\begin{array}{c}0.057 \\
(0.263)\end{array}$ & $\begin{array}{l}-0.420 \\
(0.355)\end{array}$ & $\begin{array}{l}-0.145 \\
(0.238)\end{array}$ & $\begin{array}{l}-0.346 \\
(0.340)\end{array}$ \\
\hline Government consumption & $\begin{array}{c}0.047 \\
(0.164)\end{array}$ & $\begin{array}{l}-0.051 \\
(0.306)\end{array}$ & $\begin{array}{l}-0.119 \\
(0.331)\end{array}$ & $\begin{array}{l}-0.006 \\
(0.129)\end{array}$ \\
\hline Investments & $\begin{array}{c}0.221 \\
(0.209)\end{array}$ & $\begin{array}{c}0.256 \\
(0.186)\end{array}$ & $\begin{array}{c}0.193 \\
(0.158)\end{array}$ & $\begin{array}{c}0.198 \\
(0.173)\end{array}$ \\
\hline Natural resource rents (lagged one period) & & $\begin{array}{c}2.162 \\
(1.442)\end{array}$ & & $\begin{array}{l}1.628 * * \\
(0.760)\end{array}$ \\
\hline $\begin{array}{l}\text { Natural resource rents (lagged one period) } \times \text { Gini } \\
\text { coefficient } \\
\text { Natural resource rents (lagged one period) } \times \\
\text { Institutional quality }\end{array}$ & & $\begin{array}{l}-5.104 \\
(3.813) \\
1.818 \\
(1.248)\end{array}$ & & $\begin{array}{c}-3.742 * * \\
(1.791) \\
1.723 * \\
(0.922)\end{array}$ \\
\hline Hansen test & 0.121 & 0.524 & 0.149 & 0.684 \\
\hline Number of observations & 774 & 774 & 730 & 730 \\
\hline Number of countries & 61 & 61 & 57 & 57 \\
\hline Communist Countries Excluded & NO & NO & YES & YES \\
\hline
\end{tabular}

Notes: Dependent variable is real GDP per capita growth (annual percent) measured by $\left(\log \operatorname{GDP}_{t}-\log \operatorname{lDP}_{\mathrm{t}-1}\right)$. Year fixed effects are included in all of the estimations. Arellano-Bond estimation is by two-step GMM procedure. All variables, except growth of terms of trade and the year effects are instrumented with a maximum of 2 further lags. The figures reported for the Hansen overidentification test, are p-values for the null hypothesis of valid instruments with $\chi^{2}(8)$. Total number of instruments is 35 . Robust standard errors are reported in parentheses.

*** Significant at the 1 percent level. ** Significant at the 5 percent level. * Significant at the 10 percent level.

regressions like the ones I consider here. This estimator incorporates more informative moment conditions by using a set of instruments which includes first differences in addition to lagged levels for a system of level equations along with first differenced equations. Second, the number of instruments used in difference and system GMM estimations directly impacts the results. Although more instruments should provide no worse a fit for the model, too many 
Table 12: Arellano-Bond Estimation; Robustness Check Using Residuals (Two Lags)

\begin{tabular}{|c|c|c|c|c|}
\hline Variables & $\begin{array}{c}\text { (1) } \\
\text { (Current Natural } \\
\text { Resource Rents) } \\
\end{array}$ & $\begin{array}{c}\text { (2) } \\
\text { (Lagged Natural } \\
\text { Resource Rents) } \\
\end{array}$ & $\begin{array}{c}\text { (3) } \\
\text { (Current Natural } \\
\text { Resource Rents) } \\
\end{array}$ & $\begin{array}{c}\text { (4) } \\
\text { (Lagged Natural } \\
\text { Resource Rents) }\end{array}$ \\
\hline Log of GDP per capita (lagged one period) & $\begin{array}{l}-0.208 \\
(0.359)\end{array}$ & $\begin{array}{l}-0.033 \\
(0.268)\end{array}$ & $\begin{array}{l}-0.554 \\
(0.640)\end{array}$ & $\begin{array}{l}-0.113 \\
(0.226)\end{array}$ \\
\hline Log of GDP per capita (lagged one period) squared & $\begin{array}{c}0.015 \\
(0.024)\end{array}$ & $\begin{array}{c}0.004 \\
(0.018)\end{array}$ & $\begin{array}{c}0.038 \\
(0.044)\end{array}$ & $\begin{array}{c}0.009 \\
(0.015)\end{array}$ \\
\hline Natural resource rents & $\begin{array}{c}0.684 \\
(0.583)\end{array}$ & & $\begin{array}{c}0.872 \\
(0.655)\end{array}$ & \\
\hline Natural resource rents $\times$ Residuals & $\begin{array}{c}1.772 \\
(7.312)\end{array}$ & & $\begin{array}{l}-4.465 \\
(4.248)\end{array}$ & \\
\hline Inflation & $\begin{array}{l}-0.002 * \\
(0.001)\end{array}$ & $\begin{array}{l}-0.001 \\
(0.001)\end{array}$ & $\begin{array}{l}-0.001 \\
(0.001)\end{array}$ & $\begin{array}{l}-0.002 * \\
(0.001)\end{array}$ \\
\hline Institutional quality & $\begin{array}{c}0.189 \\
(0.277)\end{array}$ & $\begin{array}{l}-0.154 \\
(0.231)\end{array}$ & $\begin{array}{c}0.216 \\
(0.265)\end{array}$ & $\begin{array}{l}-0.165 \\
(0.195)\end{array}$ \\
\hline Natural resource rents $\times$ Institutional quality & $\begin{array}{c}-0.483 \\
(1.362)\end{array}$ & & $\begin{array}{l}-2.225 \\
(2.001)\end{array}$ & \\
\hline Growth rate of terms of trade & $\begin{array}{l}0.008 \\
(0.014)\end{array}$ & $\begin{array}{c}0.027 * * \\
(0.011)\end{array}$ & $\begin{array}{c}0.020 \\
(0.015)\end{array}$ & $\begin{array}{c}0.026^{* *} * \\
(0.010)\end{array}$ \\
\hline Log of fertility rate & $\begin{array}{l}-0.003 \\
(0.258)\end{array}$ & $\begin{array}{l}-0.573^{*} \\
(0.336)\end{array}$ & $\begin{array}{l}-0.181 \\
(0.325)\end{array}$ & $\begin{array}{l}-0.514 \\
(0.400)\end{array}$ \\
\hline Government consumption & $\begin{array}{c}0.058 \\
(0.135)\end{array}$ & $\begin{array}{l}-0.062 \\
(0.353)\end{array}$ & $\begin{array}{l}-0.099 \\
(0.363)\end{array}$ & $\begin{array}{l}-0.033 \\
(0.122)\end{array}$ \\
\hline Investments & $\begin{array}{c}0.228 \\
(0.200)\end{array}$ & $\begin{array}{c}0.278 \\
(0.204)\end{array}$ & $\begin{array}{c}0.163 \\
(0.176)\end{array}$ & $\begin{array}{c}0.238 \\
(0.190)\end{array}$ \\
\hline Natural resource rents (lagged one period) & & $\begin{array}{c}0.133 \\
(0.325)\end{array}$ & & $\begin{array}{c}0.097 \\
(0.307)\end{array}$ \\
\hline Natural resource rents (lagged one period) $\times$ Residuals & & $\begin{array}{l}-7.793^{*} \\
(4.582)\end{array}$ & & $\begin{array}{c}-4.566^{* *} \\
(1.791)\end{array}$ \\
\hline $\begin{array}{l}\text { Natural resource rents (lagged one period) } \times \\
\text { Institutional quality }\end{array}$ & & $\begin{array}{c}1.357 \\
(0.880)\end{array}$ & & $\begin{array}{c}1.327 \\
(0.828)\end{array}$ \\
\hline Hansen test & 0.088 & 0.704 & 0.279 & 0.870 \\
\hline Number of observations & 774 & 774 & 730 & 730 \\
\hline Number of countries & 61 & 61 & 57 & 57 \\
\hline Communist Countries Excluded & NO & $\mathrm{NO}$ & YES & YES \\
\hline
\end{tabular}

Notes: Dependent variable is real GDP per capita growth (annual percent) measured by $\left(\operatorname{logGDP}{ }_{t}-\log _{\mathrm{GDP}} \mathrm{t}_{-1}\right)$. In all estimations, the measure of inequality (Gini) is replaced by the residuals of regressing Gini on Institutional quality. Year fixed effects are included in all of the estimations. Arellano-Bond estimation is by two-step GMM procedure. All variables, except growth of terms of trade and the year effects are instrumented with a maximum of 2 further lags. The figures reported for the Hansen overidentification test, are p-values for the null hypothesis of valid instruments with $\chi^{2}(8)$. Total number of instruments is 35 . Robust standard errors are reported in parentheses.

$* * *$ Significant at the 1 percent level. ** Significant at the 5 percent level. * Significant at the 10 percent level.

instruments may overfit the data and weaken the validity of the Hansen over-identification test. In order to obtain reliable Hansen tests I, therefore, collapse the instruments using a method suggested by Roodman (2008) in both the difference and system GMM. In this way I can use as many instruments as possible (while still keeping the total number less than the number of countries). 
Table 13: Blundell-Bond Estimation (Two lags)

\begin{tabular}{|c|c|c|c|c|}
\hline Variables & $\begin{array}{c}\text { (1) } \\
\text { (Current Natural } \\
\text { Resource Rents) } \\
\end{array}$ & $\begin{array}{c}(2) \\
\text { (Lagged Natural } \\
\text { Resource Rents) } \\
\end{array}$ & $\begin{array}{c}\text { (3) } \\
\text { (Current Natural } \\
\text { Resource Rents) } \\
\end{array}$ & $\begin{array}{c}\text { (4) } \\
\text { (Lagged Natural } \\
\text { Resource Rents) } \\
\end{array}$ \\
\hline Log of GDP per capita (lagged one period) & $\begin{array}{l}-0.172 \\
(0.120)\end{array}$ & $\begin{array}{l}-0.132 \\
(0.125)\end{array}$ & $\begin{array}{l}-0.189 \\
(0.141)\end{array}$ & $\begin{array}{l}-0.102 \\
(0.120)\end{array}$ \\
\hline Log of GDP per capita (lagged one period) squared & $\begin{array}{c}0.012 \\
(0.009)\end{array}$ & $\begin{array}{c}0.009 \\
(0.009)\end{array}$ & $\begin{array}{c}0.013 \\
(0.010)\end{array}$ & $\begin{array}{c}0.007 \\
(0.008)\end{array}$ \\
\hline Natural resource rents & $\begin{array}{c}0.737 \\
(0.555)\end{array}$ & & $\begin{array}{l}1.000 \text { ** } \\
(0.405)\end{array}$ & \\
\hline Natural resource rents $\times$ Gini coefficient & $\begin{array}{l}-0.696 \\
(1.088)\end{array}$ & & $\begin{array}{l}-1.457 \\
(0.943)\end{array}$ & \\
\hline Inflation & $\begin{array}{c}-0.001 * * \\
(0.001)\end{array}$ & $\begin{array}{l}-0.001 \\
(0.001)\end{array}$ & $\begin{array}{c}-0.002 * * \\
(0.001)\end{array}$ & $\begin{array}{l}-0.001 \\
(0.001)\end{array}$ \\
\hline Institutional quality & $\begin{array}{c}0.145^{* *} \\
(0.072)\end{array}$ & $\begin{array}{c}0.118 * * \\
(0.055)\end{array}$ & $\begin{array}{c}0.098 \\
(0.072)\end{array}$ & $\begin{array}{c}0.097 \\
(0.066)\end{array}$ \\
\hline Natural resource rents $\times$ Institutional quality & $\begin{array}{l}-0.555 \\
(0.404)\end{array}$ & & $\begin{array}{l}-0.497 \\
(0.497)\end{array}$ & \\
\hline Growth rate of terms of trade & $\begin{array}{c}0.020^{* *} \\
(0.010)\end{array}$ & $\begin{array}{c}0.024^{* * *} \\
(0.010)\end{array}$ & $\begin{array}{c}0.018 \\
(0.011)\end{array}$ & $\begin{array}{c}0.015 \\
(0.010)\end{array}$ \\
\hline Log of fertility rate & $\begin{array}{l}-0.001 \\
(0.034)\end{array}$ & $\begin{array}{c}0.011 \\
(0.030)\end{array}$ & $\begin{array}{c}0.013 \\
(0.027)\end{array}$ & $\begin{array}{c}0.022 \\
(0.030)\end{array}$ \\
\hline Government consumption & $\begin{array}{l}-0.063 \\
(0.149)\end{array}$ & $\begin{array}{l}-0.013 \\
(0.102)\end{array}$ & $\begin{array}{c}0.017 \\
(0.089)\end{array}$ & $\begin{array}{c}0.008 \\
(0.087)\end{array}$ \\
\hline Investments & $\begin{array}{c}0.204 * * \\
(0.092)\end{array}$ & $\begin{array}{c}0.195 * * \\
(0.083)\end{array}$ & $\begin{array}{l}0.137^{*} \\
(0.075)\end{array}$ & $\begin{array}{c}0.170 * * * \\
(0.063)\end{array}$ \\
\hline Natural resource rents (lagged one period) & & $\begin{array}{c}0.535 \\
(0.373)\end{array}$ & & $\begin{array}{c}0.353 \\
(0.353)\end{array}$ \\
\hline $\begin{array}{l}\text { Natural resource rents (lagged one period) } \times \text { Gini } \\
\text { coefficient }\end{array}$ & & $\begin{array}{c}-0.988 * * \\
(0.464)\end{array}$ & & $\begin{array}{l}-0.821 * \\
(0.444)\end{array}$ \\
\hline $\begin{array}{l}\text { Natural resource rents (lagged one period) } \times \\
\text { Institutional quality }\end{array}$ & & $\begin{array}{l}-0.082 \\
(0.457)\end{array}$ & & $\begin{array}{c}0.100 \\
(0.400)\end{array}$ \\
\hline Hansen test & 0.257 & 0.521 & 0.215 & 0.333 \\
\hline Number of observations & 836 & 836 & 788 & 788 \\
\hline Number of countries & 61 & 61 & 57 & 57 \\
\hline Communist Countries Excluded & NO & NO & YES & YES \\
\hline
\end{tabular}

Notes: Dependent variable is real GDP per capita growth (annual percent) measured by $\left(\log G_{D P}-\operatorname{logGDP}_{t-1}\right)$. Year fixed effects are included in all of the estimations. Blundell-Bond estimation is by two-step GMM procedure. All variables, except growth of terms of trade and the year effects are instrumented with a maximum of 2 further lags. The figures reported for the Hansen overidentification test, are p-values for the null hypothesis of valid instruments with $\mathcal{X}^{2}(19)$. Total number of instruments is 46 . Robust standard errors are reported in parentheses.

*** Significant at the 1 percent level. ** Significant at the 5 percent level. * Significant at the 10 percent level.

As noted in the previous sections, I would want to start with using one lag for each variable in the instrumentation process, however, in a difference GMM procedure, this method will generate exact identification so that I could not verify the validity of the instruments. For this reason in the difference GMM estimation I begin by using one lag for the initial GDP and two further lags for the rest of the variables. This exact identification problem does not 
Table 14: Blundell-Bond Estimation; Robustness Check Using Residuals (Two lags)

\begin{tabular}{|c|c|c|c|c|}
\hline Variables & $\begin{array}{c}(1) \\
\text { (Current Natural } \\
\text { Resource Rents) } \\
\end{array}$ & $\begin{array}{c}\text { (2) } \\
\text { (Lagged Natural } \\
\text { Resource Rents) } \\
\end{array}$ & $\begin{array}{c}\text { (3) } \\
\text { (Current Natural } \\
\text { Resource Rents) } \\
\end{array}$ & $\begin{array}{c}\text { (4) } \\
\text { (Lagged Natural } \\
\text { Resource Rents) } \\
\end{array}$ \\
\hline Log of GDP per capita (lagged one period) & $\begin{array}{l}-0.063 \\
(0.179)\end{array}$ & $\begin{array}{l}-0.106 \\
(0.116)\end{array}$ & $\begin{array}{l}-0.123 \\
(0.139)\end{array}$ & $\begin{array}{l}-0.067 \\
(0.124)\end{array}$ \\
\hline Log of GDP per capita (lagged one period) squared & $\begin{array}{c}0.004 \\
(0.013)\end{array}$ & $\begin{array}{c}0.007 \\
(0.008)\end{array}$ & $\begin{array}{c}0.008 \\
(0.010)\end{array}$ & $\begin{array}{c}0.004 \\
(0.009)\end{array}$ \\
\hline Natural resource rents & $\begin{array}{c}0.344 \\
(0.471)\end{array}$ & & $\begin{array}{c}0.475 \\
(0.353)\end{array}$ & \\
\hline Natural resource rents $\times$ Residuals & $\begin{array}{l}-0.894 \\
(1.030)\end{array}$ & & $\begin{array}{l}-2.925 \\
(1.898)\end{array}$ & \\
\hline Inflation & $\begin{array}{c}-0.001^{* *} \\
(0.001)\end{array}$ & $\begin{array}{c}-0.001 * \\
(0.001)\end{array}$ & $\begin{array}{c}-0.002 * * * \\
(0.001)\end{array}$ & $\begin{array}{l}-0.001 \\
(0.001)\end{array}$ \\
\hline Institutional quality & $\begin{array}{c}0.158 * * \\
(0.066)\end{array}$ & $\begin{array}{c}0.135 * * \\
(0.057)\end{array}$ & $\begin{array}{c}0.129 * * \\
(0.060)\end{array}$ & $\begin{array}{l}0.122 * \\
(0.065)\end{array}$ \\
\hline Natural resource rents $\times$ Institutional quality & $\begin{array}{l}-0.267 \\
(0.944)\end{array}$ & & $\begin{array}{l}-0.712 \\
(0.712)\end{array}$ & \\
\hline Growth rate of terms of trade & $\begin{array}{l}0.022 * \\
(0.011)\end{array}$ & $\begin{array}{c}0.025 * * \\
(0.010)\end{array}$ & $\begin{array}{c}0.025 * * \\
(0.012)\end{array}$ & $\begin{array}{l}0.020 * \\
(0.011)\end{array}$ \\
\hline Log of fertility rate & $\begin{array}{c}0.004 \\
(0.037)\end{array}$ & $\begin{array}{c}0.001 \\
(0.036)\end{array}$ & $\begin{array}{c}0.013 \\
(0.038)\end{array}$ & $\begin{array}{c}0.021 \\
(0.033)\end{array}$ \\
\hline Government consumption & $\begin{array}{l}-0.098 \\
(0.134)\end{array}$ & $\begin{array}{c}0.016 \\
(0.097)\end{array}$ & $\begin{array}{l}-0.079 \\
(0.135)\end{array}$ & $\begin{array}{l}-0.001 \\
(0.086)\end{array}$ \\
\hline Investments & $\begin{array}{c}0.222 * * \\
(0.087)\end{array}$ & $\begin{array}{l}0.191 * * \\
(0.089)\end{array}$ & $\begin{array}{c}0.185 * * \\
(0.070)\end{array}$ & $\begin{array}{c}0.178 * * * \\
(0.067)\end{array}$ \\
\hline Natural resource rents (lagged one period) & & $\begin{array}{c}0.164 \\
(0.227)\end{array}$ & & $\begin{array}{c}0.148 \\
(0.207)\end{array}$ \\
\hline Natural resource rents (lagged one period) $\times$ Residuals & & $\begin{array}{c}-1.092 * * \\
(0.525)\end{array}$ & & $\begin{array}{c}-1.366^{* *} \\
(0.642)\end{array}$ \\
\hline $\begin{array}{l}\text { Natural resource rents (lagged one period) } \times \\
\text { Institutional quality }\end{array}$ & & $\begin{array}{l}-0.158 \\
(0.470)\end{array}$ & & $\begin{array}{l}-0.219 \\
(0.456)\end{array}$ \\
\hline Hansen test & 0.366 & 0.511 & 0.396 & 0.317 \\
\hline $\begin{array}{l}\text { Number of observations } \\
\text { Number of countries } \\
\text { Communist Countries Excluded }\end{array}$ & $\begin{array}{c}836 \\
61 \\
\mathrm{NO}\end{array}$ & $\begin{array}{c}836 \\
61 \\
\mathrm{NO}\end{array}$ & $\begin{array}{c}788 \\
57 \\
\text { YES }\end{array}$ & $\begin{array}{c}788 \\
57 \\
\mathrm{YES}\end{array}$ \\
\hline
\end{tabular}

Notes: Dependent variable is real GDP per capita growth (annual percent) measured by $\left(\log G_{D P}-\operatorname{logGDP}{ }_{t-1}\right)$. In all estimations, the measure of inequality (Gini) is replaced by the residuals of regressing Gini on Institutional quality. Year fixed effects are included in all of the estimations. Blundell-Bond estimation is by two-step GMM procedure. All variables, except growth of terms of trade and the year effects are instrumented with a maximum of 2 further lags. The figures reported for the Hansen overidentification test, are p-values for the null hypothesis of valid instruments with $X^{2}(19)$. Total number of instruments is 46 . Robust standard errors are reported in parentheses.

*** Significant at the 1 percent level. ** Significant at the 5 percent level. * Significant at the 10 percent level.

occur with system GMM estimation.

Given the 61 countries that I have in the sample, this method generates a moderate number of instruments that is neither too small to have explanatory power, nor too large to overfit the variables. ${ }^{38}$ In what follows I present the results of my GMM estimations using different

\footnotetext{
${ }^{38}$ In this case, the difference GMM estimator generates 33 instruments.
} 
Table 15: Arellano-Bond Estimation (Three lags)

\begin{tabular}{|c|c|c|c|c|}
\hline Variables & $\begin{array}{c}\text { (1) } \\
\text { (Current Natural } \\
\text { Resource Rents) } \\
\end{array}$ & $\begin{array}{c}(2) \\
\text { (Lagged Natural } \\
\text { Resource Rents) } \\
\end{array}$ & $\begin{array}{c}\text { (3) } \\
\text { (Current Natural } \\
\text { Resource Rents) } \\
\end{array}$ & $\begin{array}{c}(4) \\
\text { (Lagged Natural } \\
\text { Resource Rents) } \\
\end{array}$ \\
\hline Log of GDP per capita (lagged one period) & $\begin{array}{l}-0.596 \\
(0.384)\end{array}$ & $\begin{array}{l}-0.112 \\
(0.240)\end{array}$ & $\begin{array}{c}-0.705^{* *} \\
(0.345)\end{array}$ & $\begin{array}{l}-0.319 \\
(0.193)\end{array}$ \\
\hline Log of GDP per capita (lagged one period) squared & $\begin{array}{c}0.041 \\
(0.027)\end{array}$ & $\begin{array}{c}0.009 \\
(0.017)\end{array}$ & $\begin{array}{c}0.049 * * \\
(0.024)\end{array}$ & $\begin{array}{l}0.023 * \\
(0.013)\end{array}$ \\
\hline Natural resource rents & $\begin{array}{l}-0.879 \\
(2.508)\end{array}$ & & $\begin{array}{c}0.924 \\
(0.663)\end{array}$ & \\
\hline Natural resource rents $\times$ Gini coefficient & $\begin{array}{c}4.296 \\
(6.215)\end{array}$ & & $\begin{array}{l}-0.449 \\
(1.471)\end{array}$ & \\
\hline Inflation & $\begin{array}{l}-0.001 \\
(0.001)\end{array}$ & $\begin{array}{l}-0.001 \\
(0.001)\end{array}$ & $\begin{array}{l}-0.000 \\
(0.001)\end{array}$ & $\begin{array}{l}-0.001 \\
(0.000)\end{array}$ \\
\hline Institutional quality & $\begin{array}{l}0.386^{*} \\
(0.197)\end{array}$ & $\begin{array}{c}0.104 \\
(0.143)\end{array}$ & $\begin{array}{c}0.265^{* *} \\
(0.113)\end{array}$ & $\begin{array}{l}0.144^{*} \\
(0.083)\end{array}$ \\
\hline Natural resource rents $\times$ Institutional quality & $\begin{array}{l}-2.203 \\
(1.601)\end{array}$ & & $\begin{array}{l}-1.769^{*} \\
(0.926)\end{array}$ & \\
\hline Growth rate of terms of trade & $\begin{array}{c}0.018 \\
(0.013)\end{array}$ & $\begin{array}{c}0.026 \\
(0.016)\end{array}$ & $\begin{array}{c}0.017 \\
(0.012)\end{array}$ & $\begin{array}{c}0.027^{* * * *} \\
(0.010)\end{array}$ \\
\hline Log of fertility rate & $\begin{array}{c}0.162 \\
(0.269)\end{array}$ & $\begin{array}{l}-0.188 \\
(0.215)\end{array}$ & $\begin{array}{l}-0.110 \\
(0.249)\end{array}$ & $\begin{array}{l}-0.124 \\
(0.184)\end{array}$ \\
\hline Government consumption & $\begin{array}{l}-0.026 \\
(0.273)\end{array}$ & $\begin{array}{l}-0.245 \\
(0.318)\end{array}$ & $\begin{array}{c}0.032 \\
(0.208)\end{array}$ & $\begin{array}{c}0.054 \\
(0.166)\end{array}$ \\
\hline Investments & $\begin{array}{c}0.128 \\
(0.221)\end{array}$ & $\begin{array}{c}0.299 \\
(0.195)\end{array}$ & $\begin{array}{c}0.063 \\
(0.141)\end{array}$ & $\begin{array}{c}0.183 \\
(0.135)\end{array}$ \\
\hline Natural resource rents (lagged one period) & & $\begin{array}{l}1.644^{*} \\
(0.871)\end{array}$ & & $\begin{array}{l}1.124 * * \\
(0.465)\end{array}$ \\
\hline $\begin{array}{l}\text { Natural resource rents (lagged one period) } \times \text { Gini } \\
\text { coefficient }\end{array}$ & & $\begin{array}{l}-3.676^{*} \\
(2.109)\end{array}$ & & $\begin{array}{c}-2.109 * * \\
(0.963)\end{array}$ \\
\hline $\begin{array}{l}\text { Natural resource rents (lagged one period) } \times \\
\text { Institutional quality }\end{array}$ & & $\begin{array}{c}0.673 \\
(0.767)\end{array}$ & & $\begin{array}{c}0.582 \\
(0.546)\end{array}$ \\
\hline Hansen test & 0.309 & 0.421 & 0.488 & 0.727 \\
\hline Number of observations & 774 & 774 & 730 & 730 \\
\hline Number of countries & 61 & 61 & 57 & 57 \\
\hline Communist Countries Excluded & NO & NO & YES & YES \\
\hline
\end{tabular}

numbers of instruments to assure the reader that my results are not solely driven by a specific number of instruments.

Table 11 and table 12 present the results of the Arellano-Bond estimation using two instruments for both the predetermined and endogenous variables. The estimations in table 11 use the gini coefficient to measure inequality. In table 12 the residuals of regressing gini on 
Table 16: Arellano-Bond Estimation; Robustness Check Using Residuals (Three lags)

\begin{tabular}{|c|c|c|c|c|}
\hline Variables & $\begin{array}{c}\text { (1) } \\
\text { (Current Natural } \\
\text { Resource Rents) } \\
\end{array}$ & $\begin{array}{c}(2) \\
\text { (Lagged Natural } \\
\text { Resource Rents) } \\
\end{array}$ & $\begin{array}{c}\text { (3) } \\
\text { (Current Natural } \\
\text { Resource Rents) } \\
\end{array}$ & $\begin{array}{c}\text { (4) } \\
\text { (Lagged Natural } \\
\text { Resource Rents) } \\
\end{array}$ \\
\hline Log of GDP per capita (lagged one period) & $\begin{array}{l}-0.505 \\
(0.304)\end{array}$ & $\begin{array}{l}-0.232 \\
(0.238)\end{array}$ & $\begin{array}{c}-0.688 * * * \\
(0.253)\end{array}$ & $\begin{array}{l}-0.321 \\
(0.225)\end{array}$ \\
\hline Log of GDP per capita (lagged one period) squared & $\begin{array}{c}0.035 \\
(0.021)\end{array}$ & $\begin{array}{c}0.017 \\
(0.017)\end{array}$ & $\begin{array}{c}0.048^{* * * *} \\
(0.018)\end{array}$ & $\begin{array}{c}0.023 \\
(0.016)\end{array}$ \\
\hline Natural resource rents & $\begin{array}{c}0.855 \\
(0.548)\end{array}$ & & $\begin{array}{l}1.101 * * \\
(0.506)\end{array}$ & \\
\hline Natural resource rents $\times$ Residuals & $\begin{array}{c}2.403 \\
(5.959)\end{array}$ & & $\begin{array}{l}-4.962 \\
(3.122)\end{array}$ & \\
\hline Inflation & $\begin{array}{l}-0.001 \\
(0.000)\end{array}$ & $\begin{array}{l}-0.001 \\
(0.001)\end{array}$ & $\begin{array}{l}-0.001 \\
(0.000)\end{array}$ & $\begin{array}{l}-0.000 \\
(0.001)\end{array}$ \\
\hline Institutional quality & $\begin{array}{c}0.342 \\
(0.216)\end{array}$ & $\begin{array}{c}0.122 \\
(0.141)\end{array}$ & $\begin{array}{c}0.282 * * \\
(0.108)\end{array}$ & $\begin{array}{l}0.163 * \\
(0.085)\end{array}$ \\
\hline Natural resource rents $\times$ Institutional quality & $\begin{array}{l}-1.678 \\
(1.434)\end{array}$ & & $\begin{array}{l}-2.494 * * \\
(1.127)\end{array}$ & \\
\hline Growth rate of terms of trade & $\begin{array}{c}0.013 \\
(0.013)\end{array}$ & $\begin{array}{l}0.027 * \\
(0.013)\end{array}$ & $\begin{array}{l}0.019^{*} \\
(0.010)\end{array}$ & $\begin{array}{l}0.024 * * \\
(0.010)\end{array}$ \\
\hline Log of fertility rate & $\begin{array}{c}0.162 \\
(0.225)\end{array}$ & $\begin{array}{l}-0.279 \\
(0.184)\end{array}$ & $\begin{array}{l}-0.201 \\
(0.233)\end{array}$ & $\begin{array}{l}-0.132 \\
(0.207)\end{array}$ \\
\hline Government consumption & $\begin{array}{l}-0.084 \\
(0.183)\end{array}$ & $\begin{array}{l}-0.054 \\
(0.303)\end{array}$ & $\begin{array}{c}0.078 \\
(0.194)\end{array}$ & $\begin{array}{c}0.021 \\
(0.145)\end{array}$ \\
\hline Investments & $\begin{array}{c}0.186 \\
(0.227)\end{array}$ & $\begin{array}{l}0.338^{*} \\
(0.196)\end{array}$ & $\begin{array}{c}0.072 \\
(0.133)\end{array}$ & $\begin{array}{c}0.197 \\
(0.173)\end{array}$ \\
\hline Natural resource rents (lagged one period) & & $\begin{array}{c}0.303 \\
(0.314)\end{array}$ & & $\begin{array}{c}0.363 \\
(0.220)\end{array}$ \\
\hline Natural resource rents (lagged one period) $\times$ Residuals & & $\begin{array}{c}-6.238^{* * *} \\
(2.643)\end{array}$ & & $\begin{array}{c}-3.119^{* *} \\
(1.512)\end{array}$ \\
\hline $\begin{array}{l}\text { Natural resource rents (lagged one period) × } \\
\text { Institutional quality }\end{array}$ & & $\begin{array}{c}0.152 \\
(0.608)\end{array}$ & & $\begin{array}{c}0.011 \\
(0.547)\end{array}$ \\
\hline Hansen test & 0.326 & 0.791 & 0.693 & 0.672 \\
\hline Number of observations & 774 & 774 & 730 & 730 \\
\hline Number of countries & 61 & 61 & 57 & 57 \\
\hline Communist Countries Excluded & $\mathrm{NO}$ & NO & YES & YES \\
\hline
\end{tabular}

institutional quality and institutional quality squared are used in place of the gini coefficient. The results of the Blundell-Bond estimation using two lags are presented in table 13 and table 14 where gini and the residuals (correspondingly) are used in the estimations.

These findings suggest that although adding more instruments improves the fit of the model, 
Table 17: Blundell-Bond Estimation (Three lags)

\begin{tabular}{|c|c|c|c|c|}
\hline Variables & $\begin{array}{c}(1) \\
\text { (Current Natural } \\
\text { Resource Rents) } \\
\end{array}$ & $\begin{array}{c}(2) \\
\text { (Lagged Natural } \\
\text { Resource Rents) } \\
\end{array}$ & $\begin{array}{c}\text { (3) } \\
\text { (Current Natural } \\
\text { Resource Rents) } \\
\end{array}$ & $\begin{array}{c}(4) \\
\text { (Lagged Natural } \\
\text { Resource Rents) } \\
\end{array}$ \\
\hline Log of GDP per capita (lagged one period) & $\begin{array}{l}-0.142 \\
(0.090)\end{array}$ & $\begin{array}{l}-0.100 \\
(0.104)\end{array}$ & $\begin{array}{l}-0.161 \\
(0.110)\end{array}$ & $\begin{array}{l}-0.094 \\
(0.107)\end{array}$ \\
\hline Log of GDP per capita (lagged one period) squared & $\begin{array}{c}0.009 \\
(0.006)\end{array}$ & $\begin{array}{c}0.007 \\
(0.007)\end{array}$ & $\begin{array}{c}0.011 \\
(0.008)\end{array}$ & $\begin{array}{c}0.006 \\
(0.008)\end{array}$ \\
\hline Natural resource rents & $\begin{array}{c}0.438 \\
(0.376)\end{array}$ & & $\begin{array}{c}0.753 \\
(0.534)\end{array}$ & \\
\hline Natural resource rents $\times$ Gini coefficient & $\begin{array}{l}-0.199 \\
(0.571)\end{array}$ & & $\begin{array}{l}-0.876 \\
(1.213)\end{array}$ & \\
\hline Inflation & $\begin{array}{c}-0.001 * * \\
(0.000)\end{array}$ & $\begin{array}{l}-0.001 \\
(0.000)\end{array}$ & $\begin{array}{c}-0.001 * * \\
(0.001)\end{array}$ & $\begin{array}{l}-0.001 \\
(0.001)\end{array}$ \\
\hline Institutional quality & $\begin{array}{c}0.180 * * * \\
(0.051)\end{array}$ & $\begin{array}{c}0.176 * * * \\
(0.051)\end{array}$ & $\begin{array}{c}0.157 * * \\
(0.066)\end{array}$ & $\begin{array}{c}0.157^{* * * *} \\
(0.053)\end{array}$ \\
\hline Natural resource rents $\times$ Institutional quality & $\begin{array}{l}-0.368 \\
(0.355)\end{array}$ & & $\begin{array}{l}-0.581 \\
(0.373)\end{array}$ & \\
\hline Growth rate of terms of trade & $\begin{array}{c}0.023 * * \\
(0.010)\end{array}$ & $\begin{array}{c}0.025 * * \\
(0.010)\end{array}$ & $\begin{array}{l}0.023^{*} \\
(0.011)\end{array}$ & $\begin{array}{l}0.021 * \\
(0.011)\end{array}$ \\
\hline Log of fertility rate & $\begin{array}{l}-0.015 \\
(0.029)\end{array}$ & $\begin{array}{c}0.008 \\
(0.029)\end{array}$ & $\begin{array}{c}0.015 \\
(0.021)\end{array}$ & $\begin{array}{c}0.027 \\
(0.023)\end{array}$ \\
\hline Government consumption & $\begin{array}{l}-0.072 \\
(0.062)\end{array}$ & $\begin{array}{l}-0.054 \\
(0.073)\end{array}$ & $\begin{array}{l}-0.079 \\
(0.071)\end{array}$ & $\begin{array}{l}-0.097 \\
(0.069)\end{array}$ \\
\hline Investments & $\begin{array}{c}0.201^{* * * *} \\
(0.075)\end{array}$ & $\begin{array}{c}0.220 * * * \\
(0.078)\end{array}$ & $\begin{array}{c}0.182 * * \\
(0.071)\end{array}$ & $\begin{array}{c}0.196 * * * \\
(0.056)\end{array}$ \\
\hline Natural resource rents (lagged one period) & & $\begin{array}{c}0.330 \\
(0.351)\end{array}$ & & $\begin{array}{c}0.415 \\
(0.342)\end{array}$ \\
\hline $\begin{array}{l}\text { Natural resource rents (lagged one period) } \times \text { Gini } \\
\text { coefficient }\end{array}$ & & $\begin{array}{l}-0.440 \\
(0.492)\end{array}$ & & $\begin{array}{l}-0.751 \\
(0.602)\end{array}$ \\
\hline $\begin{array}{l}\text { Natural resource rents (lagged one period) } \times \\
\text { Institutional quality }\end{array}$ & & $\begin{array}{l}-0.090 \\
(0.325)\end{array}$ & & $\begin{array}{l}-0.051 \\
(0.338)\end{array}$ \\
\hline Hansen test & 0.537 & 0.533 & 0.249 & 0.384 \\
\hline Number of observations & 836 & 836 & 788 & 788 \\
\hline Number of countries & 61 & 61 & 57 & 57 \\
\hline Communist Countries Excluded & $\mathrm{NO}$ & $\mathrm{NO}$ & YES & YES \\
\hline
\end{tabular}

nothing else changes in terms of the presence of the threshold effect that I found earlier, specially when the residuals are taken into account.

Next, I examine these estimations using the maximum number of instruments possible, which is three instruments for each variable (three lags for each endogenous and predetermined variable). Table 15 presents these results using the gini coefficient. In table 16 the gini coefficient is replaced by the residuals in all regressions. 
Table 18: Blundell-Bond Estimation; Robustness Check Using Residuals (Three lags)

\begin{tabular}{|c|c|c|c|c|}
\hline Variables & $\begin{array}{c}(1) \\
\text { (Current Natural } \\
\text { Resource Rents) } \\
\end{array}$ & $\begin{array}{c}(2) \\
\text { (Lagged Natural } \\
\text { Resource Rents) } \\
\end{array}$ & $\begin{array}{c}\text { (3) } \\
\text { (Current Natural } \\
\text { Resource Rents) } \\
\end{array}$ & $\begin{array}{c}(4) \\
\text { (Lagged Natural } \\
\text { Resource Rents) }\end{array}$ \\
\hline Log of GDP per capita (lagged one period) & $\begin{array}{l}-0.128 \\
(0.129)\end{array}$ & $\begin{array}{l}-0.085 \\
(0.095)\end{array}$ & $\begin{array}{l}-0.173 \\
(0.108)\end{array}$ & $\begin{array}{l}-0.089 \\
(0.099)\end{array}$ \\
\hline Log of GDP per capita (lagged one period) squared & $\begin{array}{c}0.009 \\
(0.009)\end{array}$ & $\begin{array}{l}0.006 \\
(0.007)\end{array}$ & $\begin{array}{c}0.012 \\
(0.008)\end{array}$ & $\begin{array}{c}0.006 \\
(0.007)\end{array}$ \\
\hline Natural resource rents & $\begin{array}{c}0.529 \\
(0.341)\end{array}$ & & $\begin{array}{c}0.630^{* *} \\
(0.246)\end{array}$ & \\
\hline Natural resource rents $\times$ Residuals & $\begin{array}{l}-0.968 \\
(0.739)\end{array}$ & & $\begin{array}{c}-3.431 * * \\
(1.671)\end{array}$ & \\
\hline Inflation & $\begin{array}{l}-0.001 \\
(0.001)\end{array}$ & $\begin{array}{l}-0.001 \\
(0.000)\end{array}$ & $\begin{array}{c}-0.001 * \\
(0.000)\end{array}$ & $\begin{array}{c}-0.001 * \\
(0.001)\end{array}$ \\
\hline Institutional quality & $\begin{array}{c}0.189 * * * \\
(0.054)\end{array}$ & $\begin{array}{c}0.179 * * * \\
(0.044)\end{array}$ & $\begin{array}{c}0.149 * * * \\
(0.053)\end{array}$ & $\begin{array}{c}0.160^{* * *} \\
(0.044)\end{array}$ \\
\hline Natural resource rents $\times$ Institutional quality & $\begin{array}{l}-0.643 \\
(0.629)\end{array}$ & & $\begin{array}{c}-1.054 * * \\
(0.498)\end{array}$ & \\
\hline Growth rate of terms of trade & $\begin{array}{l}0.021^{*} \\
(0.011)\end{array}$ & $\begin{array}{c}0.023 * * \\
(0.010)\end{array}$ & $\begin{array}{c}0.026 * * \\
(0.010)\end{array}$ & $\begin{array}{c}0.024 * * \\
(0.010)\end{array}$ \\
\hline Log of fertility rate & $\begin{array}{c}0.000 \\
(0.032)\end{array}$ & $\begin{array}{c}0.025 \\
(0.026)\end{array}$ & $\begin{array}{c}0.011 \\
(0.031)\end{array}$ & $\begin{array}{c}0.025 \\
(0.024)\end{array}$ \\
\hline Government consumption & $\begin{array}{l}-0.114 \\
(0.074)\end{array}$ & $\begin{array}{c}0.008 \\
(0.106)\end{array}$ & $\begin{array}{l}-0.126^{*} \\
(0.070)\end{array}$ & $\begin{array}{l}-0.077 \\
(0.070)\end{array}$ \\
\hline Investments & $\begin{array}{c}0.225 * * * \\
(0.083)\end{array}$ & $\begin{array}{c}0.226 * * * \\
(0.082)\end{array}$ & $\begin{array}{c}0.189 * * \\
(0.071)\end{array}$ & $\begin{array}{c}0.182 * * * * \\
(0.064)\end{array}$ \\
\hline Natural resource rents (lagged one period) & & $\begin{array}{c}0.218 \\
(0.177)\end{array}$ & & $\begin{array}{c}0.241 \\
(0.156)\end{array}$ \\
\hline Natural resource rents (lagged one period) $\times$ Residuals & & $\begin{array}{c}-1.081 * * \\
(0.476)\end{array}$ & & $\begin{array}{l}-1.493^{*} \\
(0.752)\end{array}$ \\
\hline $\begin{array}{l}\text { Natural resource rents (lagged one period) } \times \\
\text { Institutional quality }\end{array}$ & & $\begin{array}{l}-0.273 \\
(0.317)\end{array}$ & & $\begin{array}{l}-0.356 \\
(0.337)\end{array}$ \\
\hline Hansen test & 0.526 & 0.577 & 0.438 & 0.467 \\
\hline Number of observations & 836 & 836 & 788 & 788 \\
\hline Number of countries & 61 & 61 & 57 & 57 \\
\hline Communist Countries Excluded & NO & $\mathrm{NO}$ & YES & YES \\
\hline
\end{tabular}

Finally, I perform a system GMM estimation using three lags and the results are presented in 17 and 18. Similar to the previous cases, my coefficient of interest stays negative and significant throughout these estimations (specially when lagged natural resource rents are taken into account and also when communist countries are excluded from the analysis).

All in all, these results suggest that my main finding (that natural resource rents can generate 
a Dutch disease only if their distribution is highly unequal) is robust and is not sensitive to the number of instruments that are used in the estimations. I also note that this result is especially apparent after one period is passed, which points to the dynamic nature of the threshold effect that is discussed in my theoretical framework.

\subsection{Cross-Sectional Analysis}

In this section I present additional empirical tests of whether the Dutch disease is more likely to occur in countries with a less equal distribution of the natural resource rents. First, in order to draw comparisons with the seminal empirical papers on the Dutch disease and the resource curse (Sachs and Warner (1997a) and Mehlum, Moene, and Torvik (2006)) I employ a cross-sectional analysis of the data and look for the relationship between resource rent distribution and growth. In particular, I replace their resource abundance measure (which includes food, beverages, animal and plant products, as well as energy and precious metals) with the measure that I used in the main text and that I call natural resource rents (which only includes energy, precious metals, and forestry products). This narrower measure of natural resources refutes the hypothesis that natural resources by themselves can cause the Dutch disease. It is only when interacted with inequality that the effect can be negative. Brunnschweiler and Bulte (2008), van der Ploeg and Poelhekke (2010), and Goderis and Collier (2012) also propose different measures of natural resources that should not suffer the same endogeneity problems as the measure used by Sachs and Warner and Mehlum et al and, like us, they find that natural resources by themselves do not cause a disease.

Although influential, it has been suggested that cross-sectional results may not be robust to better econometric specifications. In particular, they may suffer from endogeneity of the supposed independent variables and effects driven by unobservable country heterogeneity. Hence, I extend my analysis in several dimensions. First, as noted above, I introduce a more compelling measure of natural resource rents that does not include agriculture (which is most certainly endogenous as poor countries are more dependent on agriculture). Second, I also consider the relationship between institutional quality and income inequality, and I 
show that my results are robust to a similar regression where inequality is replaced by the residuals of a regression of inequality on institutional quality and its squared term. In fact, there is surprisingly little linear correlation between institutional quality and inequality. As noted in the main text one possible explanation for this finding is that (as a matter of ideology) Muslim, communist, and former communist countries have low (reported) levels of inequality.

My findings in this section (consistent with the findings in the previous sections) support my hypothesis that the Dutch disease is directly linked with how well the natural resource rents are distributed. Natural resource rents by themselves positively impact growth, however, the interaction of rents with their distribution shows that there is a critical level of my inequality measure. Whether inequality is above or below this level plays a significant role in whether being resource-rich is a blessing or a curse for a country. ${ }^{39}$

In what follows, I conduct a cross sectional analysis mainly to introduce the measure of natural resources that I use throughout my study and compare its performance with the existing Dutch disease related studies.

I begin by following the growth and natural resource curse literature and examine this relationship in a cross-country experiment as introduced by Sachs and Warner (1997a). Starting by an ordinary least squares (OLS) estimation as given by equation (50), I replicate the cross-sectional results in Mehlum et al. (2006). In order to benchmark my results, I use a data set that originally comes from Sachs and Warner (1997a,b). This data set includes 87 countries for the years between 1965 and 1990 .

$$
\text { growt }_{i}=\alpha_{0}+\alpha_{1} \operatorname{sxpr}_{i}+\alpha_{2} i q_{i}+\alpha_{3}\left(\operatorname{sxpr}_{i} \cdot i q_{i}\right)+\alpha_{4} X_{i}+\varepsilon_{i}
$$

The dependent variable growt $_{i}$ is the average growth rate of real GDP per capita between 1965 and 1990. The variable sxpr $_{i}$ is the share of primary exports in GNP in 1970 and $i q_{i}$ is

\footnotetext{
${ }^{39}$ Although my theory refers to distribution of the natural resource rents, there is no such known measure in the data. Hence, I use Gini coefficients as proxies for my desired measure. In all of my regression results, the critical level of the Gini coefficient (above which natural resource booms can cause the Dutch disease) is around the level for the USA (.41). Scandinavian countries are lower (.25-.29) and many African and Latin American countries have higher Gini coefficients (often above .5 and up to .7).
} 
the average institutional quality index in 1982-1997. This index takes values between zero and one (one indicating the best institutions). The variable $X_{i}$ includes all other explanatory variables such as initial income level in 1965, openness, investments as a share of GDP. More details on, and the definitions of the variables are presented in table 19.

\section{Table 19: Definitions and Sources of the Variables; Cross Sectional Analysis}

\begin{tabular}{|c|c|c|}
\hline Variables & Definition and Comments & $\begin{array}{l}\text { Source (Sachs and } \\
\text { Warner (1997a,b) } \\
\text { unless specified) }\end{array}$ \\
\hline Growth rate of GDP per capita & $\begin{array}{l}\text { Average annual growth in real GDP divided by the economically active population } \\
\text { between the years } 1965-1990 \text {. }\end{array}$ & \\
\hline Log GDP 1965 & Log of real GDP per capita in 1965. & \\
\hline Openness & $\begin{array}{l}\text { The fraction of years during the period } 1965-1990 \text { in which the country is rated as } \\
\text { an open economy according to the criteria in Sachs and Warner (1995). }\end{array}$ & \\
\hline Natural resource rents & $\begin{array}{l}\text { Average total natural resources rents ( } \% \text { of GDP) between the years } 1965-1990 \text {. } \\
\text { Total natural resources rents are the sum of oil rents, natural gas rents, coal rents } \\
\text { (hard and soft), mineral rents, and forest rents. }\end{array}$ & $\begin{array}{l}\text { World Bank, WDI } \\
(2013)\end{array}$ \\
\hline Investments & $\begin{array}{l}\text { Log of the ratio of real gross domestic investment (public and private) to real GDP, } \\
\text { averaged over the period } 1970-1989 .\end{array}$ & \\
\hline Institutional quality & $\begin{array}{l}\text { Average of } 6 \text { variables; Corruption in government, Rule of law, Bureaucratic } \\
\text { quality, Ethnic tensions, Repudiation of contracts by government, Risk of } \\
\text { expropriation indexed between } 0 \text { and } 10 \text { ( } 10 \text { represents highest quality of } \\
\text { institutions.) Averaged over the period } 1982-1997 \text {. }\end{array}$ & $\begin{array}{l}\text { Knack and Keefer } \\
\text { (1998), ICRG data } \\
\text { set }\end{array}$ \\
\hline Gini coefficient $(1970-1990)$ & $\begin{array}{l}\text { Average of Gini index between the years } 1970-1990 \text {. A Gini index of } 0 \text { represents } \\
\text { perfect equality, while an index of } 1 \text { implies perfect inequality. }\end{array}$ & $\begin{array}{l}\text { Deininger and Squire } \\
\text { (1996) high quality } \\
\text { data set }\end{array}$ \\
\hline Natural resource abundance & $\begin{array}{l}\text { Share of exports of primary products in GNP in 1970. Primary products or natural } \\
\text { resource exports are exports of "fuels" and "non-fuel primary products". }\end{array}$ & \\
\hline Gini coefficient (1965 - 2008) & $\begin{array}{l}\text { Average of Gini index between the years } 1965-2008 \text {. A Gini index of } 0 \text { represents } \\
\text { perfect equality, while an index of } 1 \text { implies perfect inequality. }\end{array}$ & $\begin{array}{l}\text { World Bank } \\
\text { estimates (2013) }\end{array}$ \\
\hline $\mathrm{R} / \mathrm{P} 10 \%$ & $\begin{array}{l}\text { Share of income or expenditure of the richest } 10 \text { percent group to the poorest } 10 \\
\text { percent group reported in } 2009 \text {. }\end{array}$ & $\begin{array}{l}\text { Human Development } \\
\text { Report (2009), } \\
\text { UNDP, World Bank } \\
\text { (2009) }\end{array}$ \\
\hline
\end{tabular}

Table 20 shows the results of regression (50). The first column confirms the results of Mehlum et al. (2006) on convergence, openness, investments, natural resource abundance, institutional quality and the interaction of the last two variables. Natural resources (as measured by the share of exports of primary products in GNP) on average have a negative significant impact on GDP growth. In line with Sachs and Warner's results, institutional 
quality does not seem to alter growth significantly, however, the interaction of the two has a positive and strong impact on GDP growth. This implies that an increase in natural resource abundance increases GDP growth only if the institutional quality index is higher than 0.93. For a country with institutional quality index below this threshold, being resource rich is, on average, a curse.

Next, I present my cross-sectional regression in order to compare my results with Mehlum et al. (2006). As there is no direct measure of natural resource rent distribution at the time of this analysis, I use the average Gini coefficient in 1970-1990 from the Deininger and Squire (1996) high-quality data set to proxy for inequality. Also, I consider the interaction of the Gini coefficient and natural resources to examine how the results in Mehlum et al. (2006) are affected when income inequality and institutional quality coexist. Equation (51) indicates my cross-sectional OLS estimation where $N r_{i}$ is the measure of natural resource endowments (denoting either natural resource abundance as defined in Mehlum et al. (2006) or natural resource rents as I define it) and Gini $_{i}$ captures the income inequality:

$$
\text { growth }_{i}=\alpha_{0}+\alpha_{1} N r_{i}+\alpha_{2} \text { Gini }_{i}+\alpha_{3}\left(N r_{i} \cdot G_{i n i}\right)+\alpha_{4} i q_{i}+\alpha_{5}\left(N r_{i} \cdot i q_{i}\right)+\alpha_{6} X_{i}+\varepsilon_{i}
$$

Column (2) of table 20 summarizes the results of regression (51).

When inequality comes into the picture, neither natural resource abundance nor institutional quality have any significant effects on growth. My coefficient of interest has the expected sign, however, it is not significant. Unfortunately of the 87 countries in the Sachs and Warner (1997a) and Mehlum et al. (2006) data set I only have a Gini coefficient for 36 countries during the same time frame. I utilize a different Gini below in order to increase the country coverage. Before augmenting my inequality measure, however, I address my concerns with the measure of natural resources in these previous studies.

From column (1) we see that the natural resource abundance measure used by Sachs and Warner (1997a) and Mehlum et al. (2006) shows a strong negative effect on growth. In both of these studies the coefficient on this variable is also negative and highly significant. 
Table 20: Cross Sectional Analysis

\begin{tabular}{|c|c|c|c|c|c|c|c|}
\hline Variables & $\begin{array}{c}(1) \\
\text { Mehlum et } \\
\text { al. } \\
\text { (Natural } \\
\text { resource } \\
\text { abundance) }\end{array}$ & $\begin{array}{c}(2) \\
\text { OLS } \\
\text { (Natural } \\
\text { resource } \\
\text { abundance \& } \\
\text { Average Gini } \\
\text { 1970-1990) } \\
\end{array}$ & $\begin{array}{c}(3) \\
\text { OLS } \\
\text { (Average } \\
\text { Gini 1970- } \\
1990 \text { ) }\end{array}$ & $\begin{array}{c}(4) \\
\text { OLS } \\
\text { (Average } \\
\text { Gini 1965- } \\
\text { 2008) }\end{array}$ & $\begin{array}{c}(5) \\
\text { OLS } \\
(\mathrm{R} / \mathrm{P} 10 \% \\
2009)\end{array}$ & $\begin{array}{c}(6) \\
\text { OLS } \\
\text { (Average } \\
\text { Gini 1965- } \\
2008 \text { ) }\end{array}$ & $\begin{array}{c}(7) \\
\text { OLS } \\
(\mathrm{R} / \mathrm{P} 10 \% \\
2009)\end{array}$ \\
\hline Log GDP 1965 & $\begin{array}{l}-1.260^{* * * *} \\
(0.187)\end{array}$ & $\begin{array}{l}-1.391 * * * \\
(0.290)\end{array}$ & $\begin{array}{l}-1.257 * * * \\
(0.392)\end{array}$ & $\begin{array}{c}-0.794 * * * \\
(0.213)\end{array}$ & $\begin{array}{l}-1.234 * * * \\
(0.204)\end{array}$ & $\begin{array}{l}-0.785^{* * *} \\
(0.202)\end{array}$ & $\begin{array}{l}-1.213^{* * * *} \\
(0.211)\end{array}$ \\
\hline Openness & $\begin{array}{l}1.653 * * * \\
(0.426)\end{array}$ & $\begin{array}{l}1.521 * * \\
(0.572)\end{array}$ & $\begin{array}{l}1.182^{*} \\
(0.598)\end{array}$ & $\begin{array}{l}1.582 * * * \\
(0.515)\end{array}$ & $\begin{array}{c}1.826 * * * \\
(0.487)\end{array}$ & $\begin{array}{l}1.605 * * * \\
(0.482)\end{array}$ & $\begin{array}{c}1.854 * * * \\
(0.494)\end{array}$ \\
\hline Natural resource abundance & $\begin{array}{c}-14.265 * * * \\
(3.358)\end{array}$ & $\begin{array}{c}-6.430 \\
(12.584)\end{array}$ & & & & & \\
\hline Institutional quality & $\begin{array}{l}-1.316 \\
(1.185)\end{array}$ & $\begin{array}{c}0.372 \\
(2.685)\end{array}$ & $\begin{array}{l}0.204 \\
(2.393)\end{array}$ & $\begin{array}{c}0.714 \\
(1.199)\end{array}$ & $\begin{array}{l}-0.010 \\
(1.148)\end{array}$ & $\begin{array}{l}-0.029 \\
(1.150)\end{array}$ & $\begin{array}{c}0.101 \\
(1.160)\end{array}$ \\
\hline Investments & $\begin{array}{c}0.156^{* * * *} \\
(0.022)\end{array}$ & $\begin{array}{c}0.138 * * * \\
(0.030)\end{array}$ & $\begin{array}{l}0.144 * * * \\
(0.035)\end{array}$ & $\begin{array}{c}0.117 * * * \\
(0.024)\end{array}$ & $\begin{array}{l}0.159 * * * \\
(0.024)\end{array}$ & $\begin{array}{c}0.122 * * * \\
(0.024)\end{array}$ & $\begin{array}{c}0.150 * * * \\
(0.025)\end{array}$ \\
\hline $\begin{array}{l}\text { Natural resource abundance * } \\
\text { Institutional quality }\end{array}$ & $\begin{array}{l}15.252 * * \\
(6.317)\end{array}$ & $\begin{array}{c}12.876 \\
(15.020)\end{array}$ & & & & & \\
\hline Gini coefficient $(1970-1990)$ & & $\begin{array}{c}0.028 \\
(0.037)\end{array}$ & $\begin{array}{c}0.047 \\
(0.035)\end{array}$ & & & & \\
\hline $\begin{array}{l}\text { Natural resource abundance } \times \text { Gini } \\
\text { coefficient }(1970-1990)\end{array}$ & & $\begin{array}{l}-0.149 \\
(0.268)\end{array}$ & & & & & \\
\hline Natural resource rents & & & $\begin{array}{l}0.168 \\
(0.169)\end{array}$ & $\begin{array}{l}0.500^{* * * *} \\
(0.149)\end{array}$ & $\begin{array}{c}0.039 \\
(0.074)\end{array}$ & $\begin{array}{c}0.464^{* * * *} \\
(0.138)\end{array}$ & $\begin{array}{c}0.042 \\
(0.074)\end{array}$ \\
\hline $\begin{array}{l}\text { Natural resource rents * } \\
\text { Institutional quality }\end{array}$ & & & $\begin{array}{l}0.295 \\
(0.217)\end{array}$ & $\begin{array}{c}0.017 \\
(0.106)\end{array}$ & $\begin{array}{c}0.035 \\
(0.115)\end{array}$ & $\begin{array}{c}0.136 \\
(0.105)\end{array}$ & $\begin{array}{c}0.031 \\
(0.116)\end{array}$ \\
\hline $\begin{array}{l}\text { Natural resource rents } \times \text { Gini } \\
\text { coefficient }(1970-1990)\end{array}$ & & & $\begin{array}{l}-0.008^{*} \\
(0.004)\end{array}$ & & & & \\
\hline Gini coefficient $(1965-2008)$ & & & & $\begin{array}{l}6.606^{* * *} \\
(2.773)\end{array}$ & & $\begin{array}{l}7.126 * * * \\
(2.576)\end{array}$ & \\
\hline $\begin{array}{l}\text { Natural resource rents } \times \text { Gini } \\
\text { coefficient }(1965-2008\end{array}$ & & & & $\begin{array}{c}-1.204^{* * * *} \\
(0.310)\end{array}$ & & $\begin{array}{c}-1.304 * * * \\
(0.289)\end{array}$ & \\
\hline $\mathrm{R} / \mathrm{P} 10 \%$ & & & & & $\begin{array}{l}3.373 \\
(2.094)\end{array}$ & & $\begin{array}{l}3.368 \\
(2.105)\end{array}$ \\
\hline Natural resource rents $\times \mathrm{R} / \mathrm{P} 10 \%$ & & & & & $\begin{array}{l}-0.493 * * \\
(0.226)\end{array}$ & & $\begin{array}{c}-0.497 * * \\
(0.227)\end{array}$ \\
\hline Communist Countries Excluded & NO & $\mathrm{NO}$ & NO & NO & NO & YES & YES \\
\hline Observations & 87 & 36 & 36 & 80 & 79 & 77 & 77 \\
\hline R-squared & 0.728 & 0.777 & 0.744 & 0.599 & 0.698 & 0.641 & 0.684 \\
\hline
\end{tabular}

Notes: Robust standard errors are in parentheses. Dependent variable is the average growth rate of real GDP per capita between 1965 and 1990 .

*** Significant at the 1 percent level. ** Significant at the 5 percent level. * Significant at the 10 percent level.

I am, however, concerned with the excessively wide coverage of this variable. The sectors of the economy included in this variable are all of the industries under the following SITC (revision 1) codes: 0 (food and live animals), 1 (beverages and tobacco), 2 (crude materials, inedible, except fuels), 3 (mineral fuels, lubricants and related materials), 4 (animal and vegetable oils, fats and waxes), and 68 (manufactured non-ferrous metal). This variable has 
two potential problems. First, most of these items (except code 3, which includes mining and petroleum) take us far from the underlying presumption of the Dutch disease or the resource curse. Second, low income countries are much more likely to be highly dependent on food, beverage, animal, and vegetable products (codes $0,1,2$, and 4). Hence, this variable is likely to be endogenous and it is, therefore, impossible to ascertain the direction of the causality between "natural resource abundance" and growth.

I propose instead to use what I call "natural resource rents" which includes only oil, natural gas, coal, mineral, and forest rents (codes 3 and 23-25) and I introduce it in column 3. Although I do not claim that the substitution of rents for abundance entirely solves the possible endogeneity problem (I attempt to control for that in a later section) it is interesting to note that the coefficient on rents in columns 3 through 7 is now positive. Hence, natural resource rents by themselves are correlated with faster growth. This finding reduces the concerns arising from the most important reason why natural resource rents could be endogenous: that low income countries are dependent on natural resources because that is all they have. Further note that natural resources by themselves do not appear to cause the Dutch disease. More importantly, the results in column (3) show that inequality of the resource rent distribution can reverse the positive effects of resource rents on GDP growth. This implies that natural resource rents can only help the economy to grow if income inequality is lower than a threshold. In other words, what really matters for economic growth is how equally the natural resource rents are distributed. Note, however, that the coefficient on the interaction term of Gini and resource rents is rather small and significant only at the 10 percent level. I believe this is driven by the noisiness and sparseness of the Gini data for 1970-1990. The Gini coefficient is not reported for many countries in the Deininger and Squire data set in the period of 1970-1990 and the few number of countries can affect my results. In order to have a better country coverage, in column (4) I use the World Bank Gini coefficients averaged from 1965 to 2008. Although it includes many more countries, it still does not cover every year in the sample, however, Gini coefficients do not appear to change much over time and I feel comfortable using the average of the reported years. The inclusion of this additional 
data generates more pronounced results: both natural resource rents and inequality have positive significant effects and, crucially, when interacted they have a strong negative significant impact on real GDP growth. Furthermore, I note that the coefficient on institutional quality and on its interaction with natural resource rents have the expected signs, but they are not significant.

Column (5) reports the results of the same regression when the Gini coefficient is replaced by the ratio of the average income of the richest decile to the poorest decile as an alternative measure of income inequality. This index is from the United Nations Development Programme (UNDP) Human Development Report (2009) and has almost the same country coverage as the Gini coefficient between 1965 and 2008. Similar to the my previous findings, the interaction term has a significant negative impact on GDP growth and the effects of institutional quality are insignificant.

The relationship between income inequality and economic growth may differ for communist countries in the sense that these economies are generally known for low growth and bad institutions but also low income inequality. I, therefore, exempt them from my analysis to test if the results are affected by the presence of these countries. In columns (6) and (7), I test the same regression as in columns (4) and (5) while excluding communist countries from the analysis. As expected, the measured effects are more significant and more pronounced. Intuitively, given the point estimates in column (4), I can express the total effect of natural resource rents on GDP growth as

$\frac{\partial G D P \text { Growth }}{\partial \text { Natural Resource Rents }}=0.5-1.204($ Gini Coef ficient $)+.017($ Institutional Quality $)$

Consequently, (ignoring the small effect of institutional quality) a country with a Gini coefficient higher than a threshold of 0.41 (i.e. $\frac{0.5}{1.204}$ ) experiences lower GDP growth when there is a natural resource boom. This is in line with my theoretical findings suggesting that the higher the inequality, the stronger the natural resource curse. As a point of reference, the reported Gini coefficient for the USA is between .39 and .41. Others are as follows: Norway .27, Egypt and Pakistan .32, China .35, Kenya .48, Bolivia .56, Brazil .58 and Namibia .69. 
The reported Gini coefficients in my data set are all between .25 and .7

Similarly, the effect of inequality on GDP growth is given by

$$
\frac{\partial \text { GDP Growth }}{\partial \text { Gini Coefficient }}=6.606-1.204(\text { Natural Resource Rents })
$$

In other words, for a country whose natural resource rents do not exceed 5.49 percent of its GDP, more inequality enhances economic growth. On the other hand, resource-rich countries do not benefit from higher inequality in terms of their GDP growth.

Table 21: Cross Sectional Causal Inference

\begin{tabular}{|c|c|c|c|c|c|}
\hline Variables & (1) & (2) & (3) & (4) & (5) \\
\hline Log GDP 1965 & $\begin{array}{c}0.217 \\
(0.212)\end{array}$ & $\begin{array}{l}-0.331 \\
(0.212)\end{array}$ & $\begin{array}{c}-0.767 * * * \\
(0.201)\end{array}$ & $\begin{array}{c}-0.791 * * * \\
(0.210)\end{array}$ & $\begin{array}{c}-0.794 * * * \\
(0.213)\end{array}$ \\
\hline Openness & & $\begin{array}{l}3.076^{* * *} \\
(0.504)\end{array}$ & $\begin{array}{l}1.874 * * * \\
(0.490)\end{array}$ & $\begin{array}{l}1.564 * * * \\
(0.500)\end{array}$ & $\begin{array}{l}1.582 * * * \\
(0.515)\end{array}$ \\
\hline Natural resource rents & $\begin{array}{c}0.280 \\
(0.170)\end{array}$ & $\begin{array}{c}0.494 * * * \\
(0.154)\end{array}$ & $\begin{array}{l}0.426 * * * \\
(0.134)\end{array}$ & $\begin{array}{l}0.511 * * * \\
(0.134)\end{array}$ & $\begin{array}{l}0.500 * * * \\
(0.149)\end{array}$ \\
\hline Investments & & & $\begin{array}{c}0.119 * * * \\
(0.022)\end{array}$ & $\begin{array}{c}0.117 * * * \\
(0.024)\end{array}$ & $\begin{array}{c}0.117 * * * \\
(0.024)\end{array}$ \\
\hline Institutional quality & & & & $\begin{array}{c}0.831 \\
(0.959)\end{array}$ & $\begin{array}{c}0.714 \\
(1.199)\end{array}$ \\
\hline $\begin{array}{l}\text { Natural resource rents × } \\
\text { Institutional quality }\end{array}$ & & & & & $\begin{array}{c}0.017 \\
(0.106)\end{array}$ \\
\hline Gini coefficient $(1965-2008)$ & $\begin{array}{c}1.049 \\
(3.275)\end{array}$ & $\begin{array}{l}7.909 * * \\
(3.166)\end{array}$ & $\begin{array}{l}6.043 * * \\
(2.765)\end{array}$ & $\begin{array}{l}6.691 * * \\
(2.706)\end{array}$ & $\begin{array}{l}6.606 * * \\
(2.773)\end{array}$ \\
\hline $\begin{array}{l}\text { Natural resource rents × } \\
\text { Gini coefficient }(1965-2008)\end{array}$ & $\begin{array}{l}-0.729 * \\
(0.394)\end{array}$ & $\begin{array}{l}-1.127 * * * \\
(0.357)\end{array}$ & $\begin{array}{l}-1.022 * * * * \\
(0.310)\end{array}$ & $\begin{array}{l}-1.208 * * * \\
(0.307)\end{array}$ & $\begin{array}{l}-1.204 * * * \\
(0.310)\end{array}$ \\
\hline $\begin{array}{l}\text { Observations } \\
\text { R-squared }\end{array}$ & $\begin{array}{c}96 \\
0.123\end{array}$ & $\begin{array}{c}90 \\
0.399\end{array}$ & $\begin{array}{c}90 \\
0.554\end{array}$ & $\begin{array}{c}80 \\
0.598\end{array}$ & $\begin{array}{c}80 \\
0.599\end{array}$ \\
\hline
\end{tabular}

In order to test whether the point estimates given above are not affected by the additional explanatory variables, I examine the causal inference of my regression from column (4) of table 20. In table 21 I start in column (1) with a bare-bones regression of growth on natural resource rents, inequality, their interaction, and the initial GDP level. I successively add variables until in column (5) I reproduce the regression in column (4) of table 20. These results are presented in table 21. My coefficient of interest always remains negative and significant suggesting that the effect of the distribution of natural resource rents are not 
altered by other growth related explanatory variables.

Table 22: Cross Sectional Causal Inference Robustness Check

\begin{tabular}{|c|c|c|c|c|c|}
\hline Variables & (1) & (2) & (3) & (4) & (5) \\
\hline Log GDP 1965 & $\begin{array}{l}0.359 * \\
(0.201)\end{array}$ & $\begin{array}{l}-0.410^{*} \\
(0.215)\end{array}$ & $\begin{array}{l}-0.769 * * * \\
(0.197)\end{array}$ & $\begin{array}{c}-0.821 * * * \\
(0.213)\end{array}$ & $\begin{array}{c}-0.827 * * * \\
(0.210)\end{array}$ \\
\hline Openness & & $\begin{array}{l}2.680 * * * \\
(0.460)\end{array}$ & $\begin{array}{c}1.450 * * * \\
(0.459)\end{array}$ & $\begin{array}{l}1.338 * * * \\
(0.492)\end{array}$ & $\begin{array}{l}1.571^{* * *} \\
(0.508)\end{array}$ \\
\hline Natural resource rents & $\begin{array}{l}-0.033 \\
(0.020)\end{array}$ & $\begin{array}{c}0.001 \\
(0.019)\end{array}$ & $\begin{array}{l}-0.018 \\
(0.016)\end{array}$ & $\begin{array}{l}-0.016 \\
(0.017)\end{array}$ & $\begin{array}{l}-0.102 * \\
(0.056)\end{array}$ \\
\hline Investments & & & $\begin{array}{c}0.122 * * * \\
(0.023)\end{array}$ & $\begin{array}{l}0.119 * * * \\
(0.024)\end{array}$ & $\begin{array}{c}0.120 * * * \\
(0.024)\end{array}$ \\
\hline Institutional quality & & & & $\begin{array}{c}0.615 \\
(0.942)\end{array}$ & $\begin{array}{l}-0.494 \\
(1.159)\end{array}$ \\
\hline $\begin{array}{l}\text { Natural resource rents × } \\
\text { Institutional quality }\end{array}$ & & & & & $\begin{array}{c}0.176 \\
(0.109)\end{array}$ \\
\hline Residuals & $\begin{array}{c}5.296 \\
(3.693)\end{array}$ & $\begin{array}{l}7.342^{* *} \\
(3.251)\end{array}$ & $\begin{array}{l}5.143^{*} \\
(2.821)\end{array}$ & $\begin{array}{l}5.025^{*} \\
(2.838)\end{array}$ & $\begin{array}{l}5.866^{* * *} \\
(2.856)\end{array}$ \\
\hline $\begin{array}{l}\text { Natural resource rents } * \\
\text { Residuals }\end{array}$ & $\begin{array}{c}-1.227 * * * \\
(0.388)\end{array}$ & $\begin{array}{c}-1.190 * * * \\
(0.342)\end{array}$ & $\begin{array}{c}-1.030 * * * \\
(0.295)\end{array}$ & $\begin{array}{l}-1.019^{* * * *} \\
(0.296)\end{array}$ & $\begin{array}{l}-1.174 * * * \\
(0.308)\end{array}$ \\
\hline Observations & 83 & 80 & 80 & 80 & 80 \\
\hline R-squared & 0.176 & 0.428 & 0.585 & 0.587 & 0.602 \\
\hline
\end{tabular}

An additional concern is that the Gini coefficient and institutional quality could be correlated (either linearly or non-linearly) and, as a result, the Gini coefficient could only be capturing the effects of institutional quality on growth rather than the distributional effects. In order to remove such a possible multicollinearity problem, and check whether my results remain robust, I adopt the following procedure. I begin by regressing the Gini coefficient on institutional quality and institutional quality squared; then retrieve the residuals from this regression. I next use these residuals instead of the Gini coefficient so that I have a measure of income inequality purged from institutional quality. Table 22 presents the results of the same regressions as in table 21 with these purged Gini coefficients. My previous findings remain robust after this alteration.

I reiterate that I only include this cross-sectional analysis section to introduce my measure of natural resource rents. In particular, because it ignores country heterogeneity, time trends, more short run time effects, and any remaining possible endogeneity between the dependent 
variable and the predictors of GDP growth, it is not the preferred estimation method. Thus, in the previous sections, I consider the time inference of the effects of annual changes in the resource rents on GDP growth in my estimations, through dynamic panel data analyses.

\subsection{Conclusion}

In this chapter, I take the theoretical model introduced in section 2.3 to the data and verify that inequality plays a significant role in whether being resource-rich generates sickness or health for an economy. By creating a bridge between the Dutch disease and the natural resource curse, I test whether higher inequality levels interacted with the resource rents increase GDP growth in an economy. Using a panel of countries over 15 years, a conventional growth type regression is estimated through difference- and system-GMM. I also consider the possible effects of institutional quality along with the inequality to see if one offsets the other. In particular, to purge the effects of distribution from those of better $\mathrm{r}$ worse institutions, I conduct a robustness check in which these two effects are separated from one another. Consequently, I find that in almost all specifications the significant effects of institutional quality is absent when inequality interacted with the resource rents comes to the picture. Additionally, I conduct a cross-sectional analysis to compare my measure of natural resources to other seminal studies of this type and show that the measurement used in my analysis is more appropriate when I think of the distribution of the resulting rents. Also, by using different measures of inequality - other than the Gini coefficient - I show that the findings are not specific to a certain type of measurement.

My empirical findings support the hypothesis that the Dutch disease is directly linked with how well the natural resource rents are distributed. The negative significant estimated coefficient on the interaction of the resource rents and the Gini coefficient indicates the more unequal is this distribution, the stronger is the disease. Specifically, there exists a threshold of the Gini coefficient above which more resource rents can hurt the economy. Moreover, the results are robust to changing the number of intruments in the GMM estimations. 


\section{Chapter 4: From Paradox of Transfers to Resource Rent Distribution: Empirical Evidence on the Dutch Disease.}

\subsection{Introduction}

In this chapter further empirical evidence on the relationship between the Dutch disease and various types of windfalls is provided. First, I study the effects of two main types of international transfers that were discussed in the theoretical model in chapter 2 - i.e. foreign aid and remittances - through a different empirical strategy than chapter in 3. This new methodology takes the change in the growth of manufacturing sector as the response variable and provides a way to capture the channel through which the changes occur. Next, I apply this methodology to natural resource rents and their distribution to analyze if a more equal distribution of resource rents can lead to a positive change in the growth of the manufacturing sector.

The main question surrounding different types of intenational transfers in this chapter is whether they have a similar impact on the manufacturing sector and can ultimately present a Dutch disease effect. The most common types of foreign transfers are official development assistance (ODA) and remittances. There is a large literature (discussed in Chapter 2) that questions the effectiveness of ODA in fostering economic growth. For example, the initial good fortune of a foreign transfer could cause an appreciation of the real exchange rate that, in turn, reduces competitiveness of the manufacturing sector. This international trade related aspect of a foreign transfer is known as the Dutch disease. On the other hand, remittances are generally considered isomorphic to foreign aid in causing the disease. As such, one of the objectives of this chapter is to empirically show that this apparent similarity is false: they engender different spending behaviour and different economic outcomes. Whereas aid generates a Dutch disease effect, remittances can lead to growth.

Figure 4 depicts an increasing global trend for both the ODA and remittances in billion 
dollars, from 1980 to 2009. Given the noticeable difference in the volume of these two types of foreign transfers in the more recent years, it is important to study what the data has to offer in enlightening their possible differential effects on economic growth.

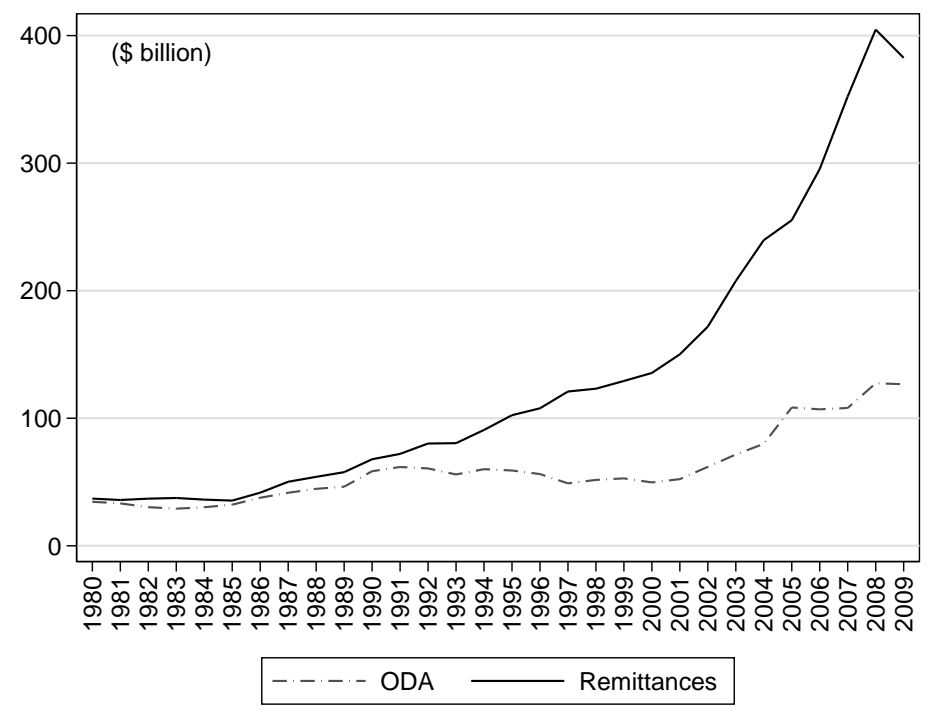

Figure 4: Official Development Assistance vs. Remittances

Furthermore, foreign aid and remittances are both important components of national income for many developing countries. The ODA was worth at least 10 percent of national income for 27 countries in 2013 and remittances made up at least 10 percent of GDP for 23 countries in the same year. ${ }^{40}$ For all recipients combined remittances totaled $\$ 410$ billion and ODA came to $\$ 160$ billion in 2013. Interestingly, a country may be a large recipient of aid or remittances, but not both. In 2013 only three countries were in the top twenty recipients of both ODA as a percent of gross national income (GNI) and remittances as a percent of GDP.

In taking the theoretical model in chapter 2 to the data I look at the change in the value added in manufacturing over the period from 1991 to 2009. I use a panel of industries and countries and consider the annual growth of each industry in each country as a separate

\footnotetext{
${ }^{40}$ The 27 countries that received ODA worth at least 10 percent of their GNI in 2013 can be ranked from Tuvalu at 48.3 percent to Niger at 10.3 percent of GNI. The countries that received remittances worth at least 10 percent of their GDP in 2013 are led by Tajikistan at 49.6 percent of GDP and in 23rd place is Nicaragua at 10 percent of GDP.
} 
observation of my dependent variable. In this way I can include a fixed effect for each country, each industry, and each year in order to control for omitted variable bias.

To control for the potential endogeneity of aid or remittances I combine two different methods in section 4.2. The first method was developed by Rajan and Zingales (1998) and later used by Rajan and Subramanian (2011) for the analysis of foreign aid's effect on growth. The idea is that not all industries are affected equally by Dutch disease effects. In particular, some industries are more sensitive to changes in the real exchange rate. This method suggest two manners of dividing the industries into more or less export sensitive groups. First, I use the fact that an increase in the real exchange rate will be more harmful in industries with lower profit margins, such as homogenous product industries, and I classify these industries as more sensitive. Second, because developing countries would not have the means to subsidize a no longer competitive export industry (even though most countries could restrict imports, not all could afford to subsidize exports), I classify typical manufactured goods from poorer developing countries as more sensitive. I then interact the dummy variable for the export sensitivity of each industry with remittances and with aid to analyze their effect on manufacturing value added to see if the effect is more pronounced in these more sensitive industries. My second method to control for any possible remaining endogeneity is to construct instruments for aid and for remittances that are based on donor, and not recipient, country characteristics.

The empirical results lend credence to my hypothesis on the difference between aid and remittances. The estimated coefficients on ODA and remittances have the predicted signs throughout and are significant in most of my empirical estimations. ${ }^{41}$

Finally, in section 4.3, I apply the RS method to natural resource rents and their distribution to study if the negative impact of less equal distribution is affecting all industries in the manufacturing sector in the same way. The results indicate that unequal distribution of resource rents impacts the more homogenous industries more than the others in the manufacturing sector. However, higher resource rents alone has a negative impact on the growth of the less homogenous industries in this sector.

\footnotetext{
${ }^{41}$ Specifications using the first measure of export sensitivity generally produced more significant results.
} 


\subsection{Paradox of Transfers}

In chapter 2 I developed three hypotheses that I could take to the data. First, foreign aid reduces the production of manufactured goods. Second, foreign aid reduces the export of manufactured goods. Third, remittances increase the production of manufactured goods. Formally, the propositions are in terms of the share of labour in the manufacturing sector, but because the labour supply is assumed constant in my model changes in output are isomorphic to the product of labour shares and any learning-by-doing. When taking the model to the data I use the fact that a single manufactured good encompasses horizontal and vertical integration across several regions and that differing goods have differing prices. The corresponding predictions should then be on the value added in the manufacturing sector. I can then restate my three hypotheses as follows: (1) foreign aid generates a reduction in the value added in the manufacturing sector; (2) remittances generate an increase in the value added in the manufacturing sector; (3) the difference between the effect of remittances and aid on the value added in the manufacturing sector is positive.

In estimating my model I look at the change in the value added in the manufacturing sector over the nineteen year period from 1991 to 2009. For this time period I have data on the changes in manufacturing value added for 23 industries and up to 56 countries. The countries and industries in my sample are listed in tables 23 and 24.

Two potential drawbacks to any cross-country regression and especially one that attempts to measure the causal effect of aid or remittances on growth is endogeneity and omitted variable bias. In order to control for the omitted variable bias I exploit the panel nature of my data and consider the growth of each industry in each country over time as a separate observation of the dependent variable. In this way I can include fixed effects to capture the average variation in each country, in each industry, and in each year.

I use two methods to control for the potential endogeneity of aid and remittances. The first method was developed by Rajan and Zingales (1998) and later used by Rajan and Subramanian (2011), hereafter referred to as RS, to consider the effect of aid on growth. The second method is to create valid instruments for aid and for remittances. 
Table 23: List of Countries

\begin{tabular}{llll}
\hline Recipients & & & \\
\hline Albania & Egypt & Malawi & South Africa \\
Algeria & Eritrea & Malaysia & Sri Lanka \\
Argentina & Ethiopia & Malta & Syrian Arab Republic \\
Azerbaijan & Fiji & Mauritius & Tanzania \\
Belarus & Georgia & Mexico & Trinidad and Tobago \\
Bolivia & India & Moldova & Tunisia \\
Botswana & Indonesia & Mongolia & Turkey \\
Brazil & Iran (Islamic Republic of) & Morocco & Uganda \\
Burundi & Iraq & Oman & Uruguay \\
Chile & Israel & Panama & Viet Nam \\
China & Jordan & Paraguay & Yemen \\
China, Macao SAR & Kenya & Peru & \\
Colombia & Korea rep. & Philippines & \\
Cyprus & Kyrgyzstan & Senegal & \\
Ecuador & Madagascar & Slovenia & \\
Donors (DAC Database) & & & Spain \\
\hline Australia & Germany & Luxembourg & Sweden \\
Austria & Greece & Netherlands & Switzerland \\
Belgium & Hungary & New Zealand & United Kingdom \\
Canada & Iceland & Norway & United States of America \\
Czech Republic & Ireland & Poland & \\
Denmark & Italy & Portugal & \\
Finland & Japan & Slovak Republic & \\
France & Korea & Slovenia & \\
\hline
\end{tabular}

The first method uses the fact that not all industries are affected equally by changes in the real exchange rate. First, any reduction in competitiveness resulting from an appreciation of the exchange rate is more likely to be felt in industries with lower profit margins such as homogeneous product industries. Second, the government of a developing country would not have the resources necessary to support a no longer profitable export. These two ideas suggest a measure of the exportability of each industry (based on the amount of differentiation in an industry and the likelihood of being a developing country export) and I then interact these derived dummy variables with remittances and with aid.

Although isolating the effect of aid and remittances on the growth of the most export sensitive industries reduces the possibility of reverse causality (unless the growth of all industries and sectors of the economy are perfectly correlated) there still may exist some lingering 
endogenous variable bias. In constructing instruments to control for any remaining possible endogenous variable bias I look for factors that are determined by the donor and not the recipient of the transfer. To this end I use the fact that the amount of remittances a country receives is correlated with the number of emigrants from that country. Emigrants from a country could still be endogenously determined by the growth in manufacturing, therefore, I use a measure of the total number of immigrants in the world (other than the country in question) which is correlated to the emigrants from my country of interest but bears little relationship to their manufacturing productivity. As an instrument for aid I construct a "supply-push aid" instrument as explained in Temple and Van de Sijpe (2017). In particular, I measure the average portion of each donor's aid received by each recipient country, over the years 1980 to 1990, which is before the start of my sample. This fraction is then multiplied by each donor's total yearly foreign aid to derive a valid instrument for each recipient's received aid in each year.

\subsubsection{Fixed Effects Estimation}

I begin my empirical analysis by estimating variations of the following fixed effects regression:

$$
\begin{aligned}
\text { growth }_{i j t} & =\beta_{0}+\beta_{1} \text { share }_{i j 90}+\beta_{2}\left(\text { exportability }_{i} \cdot \text { aid }_{j t}\right) \\
& +\beta_{3}\left(\text { exportability }_{i} \cdot \text { remittance }_{j t}\right)+\delta_{i}+\delta_{j}+\delta_{t}+\varepsilon_{i j t}
\end{aligned}
$$

Where $i$ indexes industry and $j$ indexes country and $t$ indexes year. The dependent variable growth $_{i j t}$ is the annual growth rate of value added in industry $i$ and country $j$, measured by $\left(\log (\text { valueadded })_{i j t+1}-\log (\text { valueadded })_{i j t}\right)$. The variable share $e_{i j 90}$ is the share of industry $i$ in total manufacturing value added at the beginning of the decade which captures the industry-country variations. If there exists learning-by-doing or other forms of industrywide dynamic economies of scale, then larger industries will continue to grow larger and I would expect the coefficient of the share variable to be positive. On the other hand, convergence theory would predict a negative coefficient. Although there are compelling theoretical justifications for conditional convergence of countries, it is less clear that industries would 
converge over time.

The exportability variable is an industry characteristic and captures how sensitive an industry is to changes in the relative value of exports.

Table 24: Description of ISIC Industry Divisions and Measures of Exportability

\begin{tabular}{|c|c|c|c|}
\hline $\begin{array}{l}\text { ISIC } \\
\text { Code }\end{array}$ & Description & $\begin{array}{c}\text { Exportability } \\
1 \\
\end{array}$ & $\begin{array}{c}\text { Exportability } \\
2 \\
\end{array}$ \\
\hline 15 & Manufacture of food products and beverages & 0 & 0 \\
\hline 16 & Manufacture of tobacco products & 1 & 0 \\
\hline 17 & Manufacture of textiles & 1 & 1 \\
\hline 18 & Manufacture of wearing apparel; dressing and dyeing of fur & 1 & 1 \\
\hline 19 & Tanning and dressing of leather; manufacture of luggage, handbags, and footwear & 1 & 1 \\
\hline 20 & Manufacture of wood and of products of wood and cork, except furniture & 0 & 0 \\
\hline 21 & Manufacture of paper and paper products & 0 & 0 \\
\hline 22 & Publishing, printing and reproduction of recorded media & 0 & 0 \\
\hline 23 & Manufacture of coke, refined petroleum products and nuclear fuel & 1 & 0 \\
\hline 24 & Manufacture of chemicals and chemical products & 0 & 0 \\
\hline 25 & Manufacture of rubber and plastics products & 0 & 0 \\
\hline 26 & Manufacture of other non-metallic mineral products & 0 & 0 \\
\hline 27 & Manufacture of basic metals & 1 & 0 \\
\hline 28 & Manufacture of fabricated metal products, except machinery and equipment & 0 & 0 \\
\hline 29 & Manufacture of machinery and equipment n.e.c. & 1 & 0 \\
\hline 30 & Manufacture of office, accounting and computing machinery & 1 & 0 \\
\hline 31 & Manufacture of electrical machinery and apparatus n.e.c. & 0 & 0 \\
\hline 32 & Manufacture of radio, television and communication equipment and apparatus & 1 & 0 \\
\hline 33 & Manufacture of medical, precision and optical instruments, watches and clocks & 1 & 0 \\
\hline 34 & Manufacture of motor vehicles, trailers and semi-trailers & 1 & 0 \\
\hline 35 & Manufacture of other transport equipment & 1 & 0 \\
\hline 36 & Manufacture of furniture; manufacturing n.e.c. & 0 & 0 \\
\hline 37 & Recycling & 0 & 0 \\
\hline
\end{tabular}

The measure of this sensitivity is from RS and it consists of two different forms. The first, exportability1, is a dummy variable which is 1 for those industries in which the ratio of the value of exports to value added is higher than the median of all industries and is 0 otherwise. This ratio is computed with respect to the average of all countries in the sample and is, therefore, not country specific. Industries with a high ratio have a lower profit margin and could be considered as more homogenous industries. The second measure which includes fewer industries, exportability2, is a dummy variable that is 1 for textiles, wearing apparel, leather products, and footwear and is 0 otherwise. These industries are the most common manufactured exports for poorer developing countries. A list of the industries and the value 
of each sensitivity measure for each industry is contained in Table 24.

The variable $a i d_{j t}$ is the ratio of country $j$ 's foreign aid to its GDP. Likewise, remittance $j t$ is the ratio of country $j$ 's remittance inflow to its GDP. The three fixed effects are $\delta_{i}$ for industry, $\delta_{j}$ for country, and $\delta_{t}$ for year. My coefficients of interest are $\beta_{2}$ and $\beta_{3}$. In particular, I expect that $\beta_{3}>0>\beta_{2}$ and that these two coefficients are significantly different from one another.

Table 25: Summary Statistics (1991 - 2009)

\begin{tabular}{lccccc}
\hline Variables & $\begin{array}{c}(1) \\
\text { Number of } \\
\text { Observations }\end{array}$ & $\begin{array}{c}(2) \\
\text { Mean }\end{array}$ & $\begin{array}{c}(3) \\
\text { Standard } \\
\text { Deviation }\end{array}$ & $\begin{array}{c}(4) \\
\text { Minimum }\end{array}$ & $\begin{array}{c}(5) \\
\text { Maximum }\end{array}$ \\
\hline Growth & 9,216 & 0.0402 & 0.537 & -8.201 & 7.060 \\
Aid to GDP* & 23,828 & 0.0169 & 0.0255 & 0 & 0.230 \\
Remittances to GDP & 21,344 & 0.0339 & 0.0516 & $2.90 \mathrm{e}-07$ & 0.345 \\
Exportability 1 & 24,472 & 0.522 & 0.500 & 0 & 1 \\
Exportability 2 & 24,472 & 0.130 & 0.337 & 0 & 1 \\
Initial Share & 20,520 & 0.0519 & 0.977 & -16.73 & 17.37 \\
Stock of Immigrants to GDP & 24,472 & -0.0226 & 0.102 & -0.567 & 0.0301 \\
& & & & & \\
\hline
\end{tabular}

* Summed over all DAC donors for each recipient. Similar to Temple et al (2017), summation is over all non-negative values.

** Summed over all countries but the recipient country of the remittances.

I use the most recent available data on manufacturing value added and exports for the period from 1991 to 2009. The data is from INDSTAT4 UNIDO (2015) revision 3, at the 3- and 4- digit ISIC code. It is then aggregated at the 2-digit level in order to obtain the main industry divisions as indicated by International Standard Industrial Classification revision 3. This nominal manufacturing value added is then converted to real value added using the U.S. producer price index (PPI) with a base year of 2010. Data on PPI is from the OECD data base. Foreign aid is measured by Official Development Assistance (ODA) disbursements (constant 2015 US\$) from the OECD development assistance committee database and it is later divided by GDP (constant 2005 US\$). Additionally, data on GDP and remittances are from the World Bank 2015 WDI. Table 25 provides the summary statistics for these variables.

Next, I estimate equation (53) using the constructed measures of exportability. The results 
are reported in table $26 .{ }^{42}$ The results of the fixed effects estimation using exportability 1 are presented in columns (1)-(3) and those of exportability2 are presented in columns (4)(6). Moreover, in columns (1) and (4), I apply industry, country, and year fixed effects separately, whereas in columns (2) and (5) industry and year fixed effects are combined in order to account for the year and industry characteristics jointly.

Table 26: Fixed Effects Estimation

\begin{tabular}{|c|c|c|c|c|c|c|}
\hline Variables & $(1)$ & $(2)$ & (3) & $(4)$ & $(5)$ & $(6)$ \\
\hline Initial share & $\begin{array}{c}0.056^{* * * *} \\
(0.010)\end{array}$ & $\begin{array}{c}0.056 * * * \\
(0.010)\end{array}$ & $\begin{array}{c}0.056 * * * \\
(0.011)\end{array}$ & $\begin{array}{c}0.056^{* * *} * \\
(0.011)\end{array}$ & $\begin{array}{c}0.056 * * * \\
(0.010)\end{array}$ & $\begin{array}{c}0.056 * * * \\
(0.011)\end{array}$ \\
\hline Remittances $\times$ Exportability 1 & $0.419^{* * * *}$ & $0.404 * * *$ & $0.273 * *$ & & & \\
\hline Aid $\times$ Exportability 1 & $\begin{array}{c}(0.128) \\
-1.251 * * * \\
(0.462)\end{array}$ & $\begin{array}{c}(0.145) \\
-1.228^{* *} \\
(0.486)\end{array}$ & $\begin{array}{l}(0.122) \\
-0.395 \\
(0.543)\end{array}$ & & & \\
\hline Remittances $\times$ Exportability 2 & & & & $\begin{array}{l}0.384 * * \\
(0.154)\end{array}$ & $\begin{array}{c}0.387 * * \\
(0.176)\end{array}$ & $\begin{array}{c}0.284 * * \\
(0.135)\end{array}$ \\
\hline Aid $\times$ Exportability 2 & & & & $\begin{array}{l}-1.109 \\
(0.731)\end{array}$ & $\begin{array}{l}-0.966 \\
(0.772)\end{array}$ & $\begin{array}{l}-0.568 \\
(0.600)\end{array}$ \\
\hline $\begin{array}{l}\text { Observations } \\
\text { R-squared }\end{array}$ & $\begin{array}{l}8,189 \\
0.043\end{array}$ & $\begin{array}{l}8,176 \\
0.090\end{array}$ & $\begin{array}{l}8,189 \\
0.197\end{array}$ & $\begin{array}{l}8,189 \\
0.043\end{array}$ & $\begin{array}{l}8,179 \\
0.090\end{array}$ & $\begin{array}{l}8,189 \\
0.197\end{array}$ \\
\hline $\begin{array}{l}\text { Country FE } \\
\text { Industry FE } \\
\text { Year FE } \\
\text { Industry_year FE } \\
\text { Country_year FE }\end{array}$ & $\begin{array}{l}\text { YES } \\
\text { YES } \\
\text { YES } \\
\text { NO } \\
\text { NO }\end{array}$ & $\begin{array}{l}\text { YES } \\
\text { NO } \\
\text { NO } \\
\text { YES } \\
\text { NO }\end{array}$ & $\begin{array}{l}\text { NO } \\
\text { YES } \\
\text { NO } \\
\text { NO } \\
\text { YES }\end{array}$ & $\begin{array}{l}\text { YES } \\
\text { YES } \\
\text { YES } \\
\text { NO } \\
\text { NO }\end{array}$ & $\begin{array}{l}\text { YES } \\
\text { NO } \\
\text { NO } \\
\text { YES } \\
\text { NO }\end{array}$ & $\begin{array}{l}\text { NO } \\
\text { YES } \\
\text { NO } \\
\text { NO } \\
\text { YES }\end{array}$ \\
\hline Wald test p-value & 0.0021 & 0.0046 & 0.2682 & 0.0713 & 0.1200 & 0.2077 \\
\hline
\end{tabular}

Notes: Dependant variable is annual growth rate of manufacturing value added. Foreign aid and remittances are measured as percentages of GDP. Clustered standard errors are in parentheses. A lower $p$-value indicates that $\beta_{2}$ and $\beta_{3}$ are more likely to be statistically different. $* * *$ Significant at the $1 \%$ level. ** Significant at the 5\% level. * Significant at the $10 \%$ level.

Similarly, since I am not using aid or remittances as separate variables due to the endogeneity concern, in columns (3) and (6) I use a compound country-year fixed effects to consider the simultaneous variations coming from these two dimensions.

Using the exportability measure of type one, I find that remittances have a positive and

\footnotetext{
${ }^{42}$ In all of my econometric estimations the results were very similar whether I included aid and remittances separately or simultaneously. For parsimony of presentation I only present the results for the simultaneous estimations.
} 
significant effect on the growth of those industries that are more sensitive to exports. In other words, a one percent increase in remittances to GDP results in about 0.4 percentage point faster growth in the most export-sensitive industries. On the other hand, more foreign aid reduces the pace of growth in those industries by 1.2 percent. When the second type of exportability measure is used in the estimation the results are qualitatively robust although the positive effects of remittances are smaller by 0.1 percent resulting from a fewer number of industries. More specifically, when countries receive a one percent increase in remittances (relative to GDP), the clothing and footwear industries grow about 0.3 percentage point faster compared to other less sensitive industries (where exportability $2=0$ ). At the same time, a one percent increase in the ratio of aid to GDP has no significant impact on the growth in the value added of these export sensitive industries.

Furthermore, to test whether these two coefficients (i.e. $\beta_{2}$ and $\beta_{3}$ ) are statistically distinct, I test the following null hypothesis using the Wald test:

$$
H_{0}: \beta_{2}-\beta_{3}=0
$$

The Wald test p-values presented in table 26 indicate that I can reject the equality hypothesis at the 1 percent level when the homogeneity measure of exportability is used, and at the 10 percent when the second type is considered. In other words, $\beta_{2}$ and $\beta_{3}$ are statistically different especially when I consider more exportable industries in the analysis. This implies that the impact that higher remittance inflows have on the manufacturing sector is distinct from that of foreign aid. Thus, in my sample of countries, I have found significant evidence that on average, unlike foreign aid, higher remittances have not resulted in any Dutch disease effects during the period from 1991 to 2009. Note as well that the coefficient on the initial share is always positive and significant. This discovery suggests that larger industries grow larger over time, which may result from learning-by-doing or other forms of dynamic increasing returns to scale.

Overall, my findings from the fixed effects estimation confirms that increased remittances have generated growth of the manufacturing sector, specifically in industries whose exports 
are more sensitive to changes in the real exchange rate. On the other hand, larger foreign aid inflows has had a negative effect on those same industries. Hence, I have found indications that foreign aid but not remittance, can generate a Dutch disease effect.

\subsubsection{Instrumental Variable Estimation}

In this section I seek to remove any possible remaining reverse causality between aid and remittances and the growth of industries. For instance, if aid is systematically directed to low-growth industries or if remittances are directed to high growth industries, then aid and remittances would not be exogenous and my fixed effects estimation could still pick up an effect that measures correlation rather than causality. Although any potential endogeneity arising from poorly directed transfers would be somewhat controlled for by my exportability dummy variables (and any omitted variable bias would be controlled for by the fixed effects), I still choose to construct instruments for remittances and foreign aid and further utilize a 2-stage least squares (2SLS) estimation to control for any possible remaining endogeneity or reverse causality problems.

In construction of valid instruments for both aid and remittances, I make use of donor rather

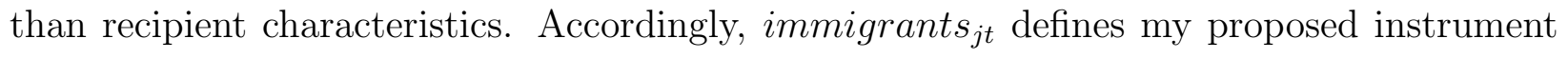
for remittances and measures the stock of immigrants as a percent of population in all countries other than country $j$ (the recipient) at any time $t$. Equation (54) mathematically expresses this constructed variable:

$$
\text { immigrants }_{j t}=\sum_{-j \in W} \text { immigrantsin }_{-j t}
$$

The data is from United Nations for 1991-2009 and $W$ is the set of all countries in this dataset.

As such, I run a 2SLS estimation on equation (53) using immigrants int $_{\text {interacted with }}$ exportability $_{i}$ as the instrumental variable. Also, I construct three additional instruments from my constructed immigrants $s_{j t}$ variable. The first accounts for nonlinearity in the relationship between my measure of immigrants and the amount of remittances received, and is 
$\left[\text { exportability }_{i} \text {. immigrants } s_{j t}\right]^{2}$. The next instrument adjusts by the relative size of country $j$ in the initial year of 1990 to consider the effectiveness of the number of people who have immigrated from country $j$ elsewhere, in terms of the amount of remittances they have sent back home, and is written as $\left(\right.$ exportability $_{i} \cdot$ immigrants $\left._{j t}\right) \cdot\left(\frac{\text { population }_{j 90}}{\text { population }_{-j t}}\right)$. By including the adjusted measure of immigrants as a separate instrument, I am picking up the differential effect that a recipient's size (relative to all other countries) might have on the amount of remittances received. The third additional instrument addresses a possible nonlinearity in this second relationship and is $\left[\left(\text { exportability }_{i} \cdot \text { immigrant }_{j t}\right) \cdot\left(\frac{\text { population }_{j 90}}{\text { population }_{-j t}}\right)\right]^{2}$.

My instrumentation strategy stems from two observations: first, since remittance inflows to a recipient country (country $j$ ) originate from the outflows of emigrants from that country, the stock of immigrants in the world (country $j$ excluded) is highly correlated with the amount of remittances country $j$ receives. Thus, my constructed variable is not only relevant but also a relatively strong instrument. Second, my instrument is directly originating from the characteristics of the host countries and is less likely to be endogenous to the growth of the manufacturing industries in the recipient country.

In addition to controlling for the endogeneity of remittances, I also use an instrument for foreign aid that originates from donors characteristics. Most of the instruments that have been suggested for aid in the aid and growth literature have been subject to criticism because the proposed instruments were still correlated with the error term and their exogeneity was not well-established. In a recent study, Temple and Van de Sijpe (2017) propose an instrument that exploits exogenous shocks to the supply of aid to the recipient countries. In order to minimize the endogeneity coming from the recipient's characteristics, I use a similar method and define a "supply-push" instrument for aid. In this approach the total amount of aid received by a recipient $j$ is re-defined as the summation of aid supplied by each donor $d$. How much each donor donates in aid to a recipient $j$, consists of the total amount of aid donated by them to all recipients in a specific year (i.e $D_{d t}$ ), times the share of recipient $j$ in donor $d$ 's supply of aid, $a_{j}^{d}$. As a result, this new measure of aid for recipient $j$ is given by: 


$$
a i d_{j t}^{S}=\sum_{d=1}^{N} a_{j}^{d} D_{d t}
$$

where $N=29$ is the total number of donors listed in table $3 \mathrm{~A}$.

Note that $a_{j}^{d}$ is an initial share and thus calculated as an average over 1980-1990 which is outside of the period under study (i.e. 1991-2009) in order to minimize contemporaneous correlation with the error term.

This instrument makes use of the assumption that the share of each recipient in the donor's aid budget remains constant over time. This is a reasonable assumption as there is not a large time variation for this calculated share in my dataset.

Table 27 presents the results of the IV first-stage estimation. In the first stage, aid and remittances interacted with the exportability measures are regressed on my measures of immigrants and of supply-push aid $\left(a i d_{j t}^{S}\right)$ both interacted with exportability measures, and the initial share of the industry. Panels A and B results show that the instruments are strongly correlated with aid and remittances. As expected the results of the first stage estimation indicate that with more immigrants in other countries, there would be more remittances received by the recipient country. The coefficient on the adjusted instrument also implies that, on average, for smaller countries this effect is larger.

I also obtain robust findings when I use different types of exportability measures. About sixty to seventy percent of the variation in both remittances and aid is explained by the stock of immigrants in other countries and the constructed measure of supply of aid. Moreover, as indicated in table 28, I test the validity and strength of my set of instruments and they pass the Stock \& Yogo (2005) weak IV test at 10 percent and the Hansen's over identification test at 5 percent.

In the second stage, "fitted remittances" and "fitted aid" replace the measures of remittances and aid that were previously used in my main regression. Table 29 presents the results of the second stage using both types of exportability measures. I find that the estimated coefficient on remittances is of the expected sign and robust when the first type of exportability is used and more industries are taken into consideration. Interestingly, the estimated coefficients on 
Table 27: IV First Stage Estimation

\begin{tabular}{|c|c|c|c|c|c|c|}
\hline Variables & $(1)$ & $(2)$ & (3) & $(4)$ & $(5)$ & $(6)$ \\
\hline \multicolumn{7}{|c|}{ Panel A-dependent variable is Aid $\times$ Exportability } \\
\hline Initial Share & $\begin{array}{c}0.000 \\
(0.000)\end{array}$ & $\begin{array}{c}0.000 \\
(0.000)\end{array}$ & $\begin{array}{c}0.000 \\
(0.000)\end{array}$ & $\begin{array}{c}0.000 \\
(0.000)\end{array}$ & $\begin{array}{c}0.000 \\
(0.000)\end{array}$ & $\begin{array}{c}0.000 \\
(0.000)\end{array}$ \\
\hline Supply-Push Aid × Exportabilityl & $\begin{array}{c}7.845^{* * * *} \\
(1.094)\end{array}$ & $\begin{array}{c}7.870 * * * \\
(1.124)\end{array}$ & $\begin{array}{c}8.388 * * * \\
(1.149)\end{array}$ & & & \\
\hline Immigrants $\times$ Exportabilityl & $\begin{array}{c}0.164 * * * \\
(0.059)\end{array}$ & $\begin{array}{c}0.161^{* *} \\
(0.066)\end{array}$ & $\begin{array}{c}0.198 * * * \\
(0.069)\end{array}$ & & & \\
\hline$(\text { Immigrants } \times \text { Exportability } 1)^{2}$ & $\begin{array}{c}0.351 * * \\
(0.136)\end{array}$ & $\begin{array}{c}0.343 * * \\
(0.155)\end{array}$ & $\begin{array}{c}0.466 * * * \\
(0.173)\end{array}$ & & & \\
\hline Adjusted Immigrants $\times$ Exportabilityl & $\begin{array}{c}-0.158 * * \\
(0.066)\end{array}$ & $\begin{array}{c}-0.155^{* *} * \\
(0.072)\end{array}$ & $\begin{array}{c}-0.203 * * \\
(0.082)\end{array}$ & & & \\
\hline$(\text { Adjusted Immigrants } \times \text { Exportabilityl) })^{2}$ & $\begin{array}{l}-0.384^{*} \\
(0.204)\end{array}$ & $\begin{array}{l}-0.369 \\
(0.223)\end{array}$ & $\begin{array}{c}-0.600 * * \\
(0.291)\end{array}$ & & & \\
\hline Supply-Push Aid × Exportability2 & & & & $\begin{array}{c}7.778 * * * * \\
(0.918)\end{array}$ & $\begin{array}{c}7.811^{* * * * *} \\
(0.969)\end{array}$ & $\begin{array}{c}7.886 * * * \\
(0.922)\end{array}$ \\
\hline Immigrants $\times$ Exportability 2 & & & & $\begin{array}{c}0.203 * * * \\
(0.070)\end{array}$ & $\begin{array}{c}0.196^{* *} \\
(0.082)\end{array}$ & $\begin{array}{c}0213 * * * \\
(0.073)\end{array}$ \\
\hline$\left(\right.$ Immigrants $\times$ Exportability2) ${ }^{2}$ & & & & $\begin{array}{c}0.469 * * * \\
(0.176)\end{array}$ & $\begin{array}{c}0.455 * * \\
(0.212)\end{array}$ & $\begin{array}{c}0.504 * * * \\
(0.185)\end{array}$ \\
\hline Adjusted Immigrants $\times$ Exportability 2 & & & & $\begin{array}{c}-0.208 * * \\
(0.079)\end{array}$ & $\begin{array}{c}-0.199 * * \\
(0.093)\end{array}$ & $\begin{array}{c}-0.221^{* *} \\
(0.084)\end{array}$ \\
\hline$(\text { Adjusted Immigrants } \times \text { Exportability } 2)^{2}$ & & & & $\begin{array}{c}-0.631 * * \\
(0.261)\end{array}$ & $\begin{array}{l}-0.601 * \\
(0.312)\end{array}$ & $\begin{array}{c}-0.693 * * \\
(0.284)\end{array}$ \\
\hline R-squared & 0.7066 & 0.7148 & 0.7650 & 0.5906 & 0.6029 & 0.6083 \\
\hline Panel B - dependent variable is Remitta & S $\times$ Expor & & & & & \\
\hline Initial Share & $\begin{array}{c}0.000^{* *} \\
(0.000)\end{array}$ & $\begin{array}{c}0.000^{* * *} \\
(0.000)\end{array}$ & $\begin{array}{c}0.000^{* * *} \\
(0.000)\end{array}$ & $\begin{array}{c}0.000 \\
(0.000)\end{array}$ & $\begin{array}{c}0.000 \\
(0.000)\end{array}$ & $\begin{array}{c}0.000 \\
(0.000)\end{array}$ \\
\hline Supply-Push Aid × Exportabilityl & $\begin{array}{c}1.719 \\
(2.801)\end{array}$ & $\begin{array}{c}1.459 \\
(2.890)\end{array}$ & $\begin{array}{c}1.672 \\
(2.884)\end{array}$ & & & \\
\hline Immigrants $\times$ Exportability 1 & $\begin{array}{c}2.080^{* * * *} \\
(0.615)\end{array}$ & $\begin{array}{c}2.074 * * * \\
(0.570)\end{array}$ & $\begin{array}{c}2.467 * * * \\
(0.562)\end{array}$ & & & \\
\hline$(\text { Immigrants } \times \text { Exportability } 1)^{2}$ & $\begin{array}{c}4.345^{* * * *} \\
(1.338)\end{array}$ & $\begin{array}{c}4.308^{* * *} \\
(1.264)\end{array}$ & $\begin{array}{c}5.439 * * * \\
(1.226)\end{array}$ & & & \\
\hline Adjusted Immigrants $\times$ Exportabilityl & $\begin{array}{c}-2.634 * * * \\
(0.686)\end{array}$ & $\begin{array}{c}-2.638 * * * \\
(0.623)\end{array}$ & $\begin{array}{c}-3.108 * * * \\
(0.638)\end{array}$ & & & \\
\hline$(\text { Adjusted Immigrants } \times \text { Exportability } 1)^{2}$ & $\begin{array}{c}-6.566 * * * \\
(1.979)\end{array}$ & $\begin{array}{c}-6.534 * * * \\
(1.831)\end{array}$ & $\begin{array}{c}-8.428^{* * *} \\
(1.850)\end{array}$ & & & \\
\hline Supply-Push Aid * Exportability2 & & & & $\begin{array}{c}0.791 \\
(2.325)\end{array}$ & $\begin{array}{c}0.606 \\
(2.479)\end{array}$ & $\begin{array}{c}0.779 \\
(2.352)\end{array}$ \\
\hline Immigrants $\times$ Exportability 2 & & & & $\begin{array}{c}2.311 * * * \\
(0.567)\end{array}$ & $\begin{array}{c}2.301 * * * \\
(0.541)\end{array}$ & $\begin{array}{c}2.426^{* * * *} \\
(0.552)\end{array}$ \\
\hline$(\text { Immigrants } \times \text { Exportability } 2)^{2}$ & & & & $\begin{array}{c}4.999^{* * *} \\
(1.285)\end{array}$ & $\begin{array}{c}4.952^{* * * *} \\
(1.271)\end{array}$ & $\begin{array}{c}5.332 * * * \\
(1.241)\end{array}$ \\
\hline Adjusted Immigrants $\times$ Exportability 2 & & & & $\begin{array}{c}-2.966 * * * \\
(0.625)\end{array}$ & $\begin{array}{c}-2.959 * * * \\
(0.589)\end{array}$ & $\begin{array}{c}-3.107 * * * \\
(0.617)\end{array}$ \\
\hline$(\text { Adjusted Immigrants } \times \text { Exportability } 2)^{2}$ & & & & $\begin{array}{l}-7.986 * * * \\
(1.723)\end{array}$ & $\begin{array}{l}-7.925 * * * \\
(1.668)\end{array}$ & $\begin{array}{c}-8.566 * * * \\
(1.715)\end{array}$ \\
\hline R-squared & 0.7216 & 0.7334 & 0.7737 & 0.5909 & 0.6030 & 0.6086 \\
\hline Hansen-Sargan Test ( $\mathcal{X}^{2}(3)$ p-value): & 0.7795 & 0.5980 & 0.5055 & 0.3144 & 0.3139 & 0.4211 \\
\hline
\end{tabular}

Notes: Foreign aid and remittances are measured as percentages of GDP. Fixed effects used in columns (1) - (6) are consistent with those in Table 3. Clustered standard errors are in parentheses. A higher Hansen-Sargan over identification test implies that the instruments are valid. $* * *$ Significant at the $1 \%$ level. ** Significant at the $5 \%$ level. * Significant at the $10 \%$ level. 
Table 28: Weak Identification Test

\begin{tabular}{|c|c|c|c|c|c|c|}
\hline Test Statistics and Critical Values & (1) & (2) & (3) & (4) & (5) & (6) \\
\hline \multicolumn{7}{|l|}{ Panel A - Wald F-Statistic } \\
\hline Cragg-Donald & 664.456 & 635.003 & 886.372 & 850.766 & 784.707 & 908.749 \\
\hline Kleibergen-Paap & 11.766 & 10.553 & 11.884 & 13.854 & 10.863 & 15.227 \\
\hline \multicolumn{7}{|c|}{ Panel B - Stock and Yogo Critical Values } \\
\hline 5\% Maximal IV Relative Bias & 13.97 & & & & & \\
\hline $10 \%$ Maximal IV Relative Bias & 8.78 & & & & & \\
\hline $20 \%$ Maximal IV Relative Bias & 5.91 & & & & & \\
\hline 30\% Maximal IV Relative Bias & 4.79 & & & & & \\
\hline $10 \%$ Maximal IV Size & 19.45 & & & & & \\
\hline $15 \%$ Maximal IV Size & 11.22 & & & & & \\
\hline 20\% Maximal IV Size & 8.38 & & & & & \\
\hline 25\% Maximal IV Size & 6.89 & & & & & \\
\hline
\end{tabular}

Notes: Columns (1) - (6) in Panel A, refer to their corresponding regressions in Table 27. Critical values are the same for all specifications. In the calculation of the critical values, iid errors are considered.

the interaction of remittances, are similar to the fixed effects case in terms of their magnitude and only about 0.2 higher when exportability1 is used in the estimation. In fact, in this case the estimated coefficients on remittances do not change drastically compared to my fixed effects estimation, suggesting that much of the endogeneity concerning remittances is resolved by using a fixed effects estimation and a specification in which each industry is affected differently by changes in the real exchange rate. When the second type of exportability is considered, however, the effects are diminished in my 2SLS specification.

Additionally, by using the instrumental variable approach for both aid and remittances I do not find significant evidence of aid generating a Dutch disease effect. More importantly, in addition to the causal positive effect of remittances on the growth of more homogenous exportable industries, I also find that the impact of remittances and foreign aid are statistically distinct at the 5 and 10 percent level. In particular, although I do not find statistically significant evidence in all cases that aid causes the Dutch disease, I find robust evidence that remittances, but not aid, increase the growth rate of the manufacturing sector. 
Table 29: IV Second Stage Estimation

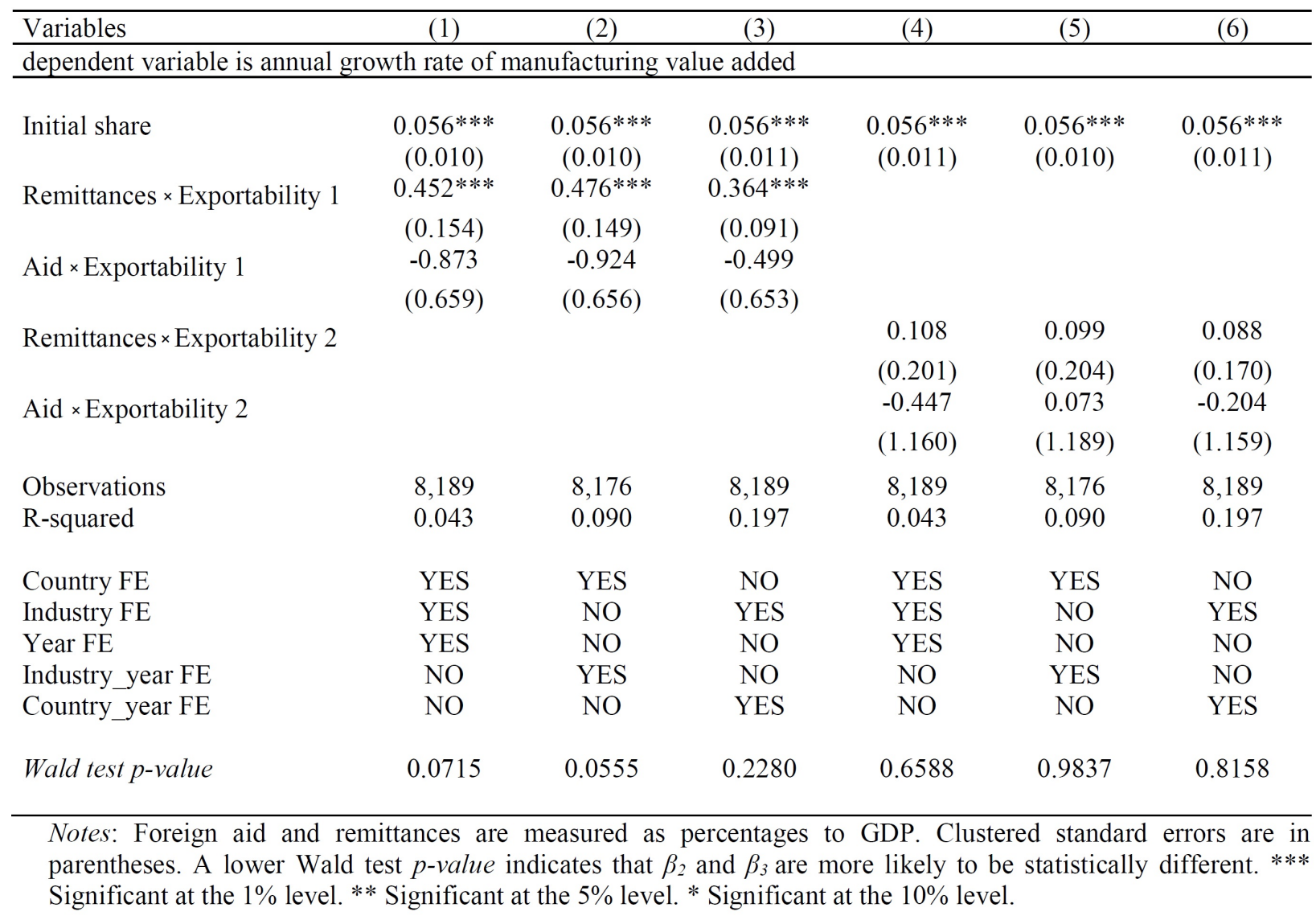

\subsection{Natural Resource Rents}

In this section, once again, I re-visit the question of distribution of the resource rents and the Dutch disease. In particular, I try to answer if the resource rents alone, or interacted with the measure of distribution, affects the growth of the manufacturing sector. To do so, I use the same measure of natural resource rents and the Gini coefficient as used in chapter 3.

Although the description of the variables is as mentioned in chapter 3, to be consistent with the data on the growth of manufacturing value added I use natural resource rents data from 1991 to 2009. Table 30 provides summary statistics for the additional variables I use in this new specification. 
Table 30: Summary Statistics; Natural Resource Rents and the Gini Coefficient (1991-2009)

\begin{tabular}{lccccc}
\hline Variables & $\begin{array}{c}(1) \\
\text { Number of } \\
\text { Observations }\end{array}$ & $\begin{array}{c}(2) \\
\text { Mean }\end{array}$ & $\begin{array}{c}(3) \\
\text { Standard } \\
\text { Deviation }\end{array}$ & $\begin{array}{c}(4) \\
\text { Minimum }\end{array}$ & $\begin{array}{c}(5) \\
\text { Maximum }\end{array}$ \\
\hline Gini Coefficient & 21,850 & 0.416 & 0.0912 & 0.248 & 0.620 \\
Natural Resource Rents (\% of GDP) & 23,207 & 0.0969 & 0.126 & 0 & 0.693 \\
\hline
\end{tabular}

\subsubsection{Fixed Effects Estimation}

I take a similar approach as in section 4.2.1 in considering the effects of the rents and their distribution on the growth of the manufacturing sector. To answer whether more resource rents increases the manufacturing growth, I test if all industries in the manufacturing sector are affected in the same way. Thus, I estimate variations of the following regression ${ }^{43}$ :

$$
\text { growt }_{i j t}=\beta_{0}+\beta_{1} \text { share }_{i j 90}+\beta_{2}\left(\text { exportability }_{i} \cdot \text { rents }_{j t}\right)+\delta_{i}+\delta_{j}+\delta_{t}+\varepsilon_{i j t}
$$

The results are presented in table 31 .

Table 31: Fixed Effects Estimation; Natural Resource Rents

\begin{tabular}{|c|c|c|c|c|c|c|}
\hline Variables & $(1)$ & $(2)$ & (3) & $(4)$ & $(5)$ & $(6)$ \\
\hline Initial share & $\begin{array}{c}0.053 * * * \\
(0.012)\end{array}$ & $\begin{array}{c}0.053 * * * \\
(0.012)\end{array}$ & $\begin{array}{c}0.054 * * * \\
(0.012)\end{array}$ & $\begin{array}{c}0.053 * * * \\
(0.012)\end{array}$ & $\begin{array}{c}0.053 * * * \\
(0.012)\end{array}$ & $\begin{array}{c}0.054^{* * *} \\
(0.012)\end{array}$ \\
\hline Natural resource rent $\times$ Exportability 1 & -0.073 & -0.073 & -0.109 & & & \\
\hline Natural resource rent $\times$ Exportability 2 & $(0.063)$ & $(0.064)$ & $(0.087)$ & $\begin{array}{c}-0.127^{*} \\
(0.066)\end{array}$ & $\begin{array}{l}-0.083 \\
(0.065)\end{array}$ & $\begin{array}{l}-0.143 * \\
(0.072)\end{array}$ \\
\hline $\begin{array}{l}\text { Observations } \\
\text { R-squared }\end{array}$ & $\begin{array}{l}8,656 \\
0.041\end{array}$ & $\begin{array}{l}8,643 \\
0.088\end{array}$ & $\begin{array}{l}8,656 \\
0.202\end{array}$ & $\begin{array}{l}8,656 \\
0.042\end{array}$ & $\begin{array}{l}8,643 \\
0.088\end{array}$ & $\begin{array}{l}8,656 \\
0.202\end{array}$ \\
\hline $\begin{array}{l}\text { Country FE } \\
\text { Industry FE } \\
\text { Year FE } \\
\text { Industry_year FE } \\
\text { Country_year FE }\end{array}$ & $\begin{array}{l}\text { YES } \\
\text { YES } \\
\text { YES } \\
\text { NO } \\
\text { NO }\end{array}$ & $\begin{array}{l}\text { YES } \\
\text { NO } \\
\text { NO } \\
\text { YES } \\
\text { NO }\end{array}$ & $\begin{array}{l}\text { NO } \\
\text { YES } \\
\text { NO } \\
\text { NO } \\
\text { YES }\end{array}$ & $\begin{array}{l}\text { YES } \\
\text { YES } \\
\text { YES } \\
\text { NO } \\
\text { NO }\end{array}$ & $\begin{array}{l}\text { YES } \\
\text { NO } \\
\text { NO } \\
\text { YES } \\
\text { NO }\end{array}$ & $\begin{array}{l}\text { NO } \\
\text { YES } \\
\text { NO } \\
\text { NO } \\
\text { YES }\end{array}$ \\
\hline $\begin{array}{l}\text { Notes: Dependant variable is annual } \\
\text { percentages of GDP. Clustered stand } \\
\text { level. * Significant at the } 10 \% \text { level. }\end{array}$ & $\begin{array}{l}\text { wh rate } \\
\text { errors are }\end{array}$ & $\begin{array}{l}\text { nufactu } \\
\text { renthese }\end{array}$ & lue add & $\begin{array}{l}\text { atural } \operatorname{Re} \\
t \text { the } 1 \%\end{array}$ & $\begin{array}{l}\text { Rents } \\
* * \text { Signi }\end{array}$ & $\begin{array}{l}\text { neasured } \\
\text { tt at the } 5\end{array}$ \\
\hline
\end{tabular}


The results show that more resource rents alone do not seem to have significant impact on the growth of the exportable industries of type one. However, when it comes to the more homogenous industries, the rents alone have negative and significant effect on value added growth in two of the specification. These findings suggest that being more resource rich (regardless of the distribution of the rents) did not significantly benefit the majority of the manufacturing industries in my panel. This impact turns out to be significant for mainly textiles and apparels, only to be reversing the pace of growth in these industries.

Table 32: Fixed Effects Estimation; Natural Resource Rents and the Distribution

\begin{tabular}{|c|c|c|c|c|c|c|}
\hline Variables & (1) & $(2)$ & (3) & $(4)$ & $(5)$ & (6) \\
\hline Initial share & $\begin{array}{c}0.054 * * * \\
(0.010)\end{array}$ & $\begin{array}{c}0.055^{* * * *} \\
(0.002)\end{array}$ & $\begin{array}{c}0.055^{* * * *} \\
(0.010)\end{array}$ & $\begin{array}{l}0.054 * * * \\
(0.010)\end{array}$ & $\begin{array}{l}0.055^{* * * *} \\
(0.009)\end{array}$ & $\begin{array}{c}0.055 * * * \\
(0.010)\end{array}$ \\
\hline Natural resource rent $\times$ Exportability 1 & $\begin{array}{c}0.273 \\
(0.172)\end{array}$ & $\begin{array}{c}0.273 \\
(0.164)\end{array}$ & $\begin{array}{c}0.106 \\
(0.184)\end{array}$ & & & \\
\hline $\begin{array}{l}\text { Natural resource rent } \times \text { Gini- } \\
\text { Coefficients } \times \text { Exportability } 1\end{array}$ & $\begin{array}{l}-1.097 * \\
(0.526)\end{array}$ & $\begin{array}{c}-1.084 * * \\
(0.538)\end{array}$ & $\begin{array}{l}-0.737 \\
(0.457)\end{array}$ & & & \\
\hline Natural resource rent $\times$ Exportability 2 & & & & $\begin{array}{l}-0.013 \\
(0.254)\end{array}$ & $\begin{array}{l}-0.037 \\
(0.233)\end{array}$ & $\begin{array}{l}-0.116 \\
(0.282)\end{array}$ \\
\hline $\begin{array}{l}\text { Natural resource rent } \times \text { Gini- } \\
\text { Coefficients } \times \text { Exportability } 2\end{array}$ & & & & $\begin{array}{l}-0.377 \\
(0.713)\end{array}$ & $\begin{array}{l}-0.144 \\
(0.637)\end{array}$ & $\begin{array}{l}-0.129 \\
(0.744)\end{array}$ \\
\hline $\begin{array}{l}\text { Observations } \\
\text { R-squared }\end{array}$ & $\begin{array}{l}7,621 \\
0.048\end{array}$ & $\begin{array}{l}7,607 \\
0.098\end{array}$ & $\begin{array}{l}7,621 \\
0.227\end{array}$ & $\begin{array}{l}7,621 \\
0.048\end{array}$ & $\begin{array}{l}7,607 \\
0.097\end{array}$ & $\begin{array}{l}7,621 \\
0.227\end{array}$ \\
\hline $\begin{array}{l}\text { Country FE } \\
\text { Industry FE } \\
\text { Year FE } \\
\text { Industry_year FE } \\
\text { Country_year FE }\end{array}$ & $\begin{array}{l}\text { YES } \\
\text { YES } \\
\text { YES } \\
\text { NO } \\
\text { NO }\end{array}$ & $\begin{array}{l}\text { YES } \\
\text { NO } \\
\text { NO } \\
\text { YES } \\
\text { NO }\end{array}$ & $\begin{array}{l}\text { NO } \\
\text { YES } \\
\text { NO } \\
\text { NO } \\
\text { YES }\end{array}$ & $\begin{array}{l}\text { YES } \\
\text { YES } \\
\text { YES } \\
\text { NO } \\
\text { NO }\end{array}$ & $\begin{array}{l}\text { YES } \\
\text { NO } \\
\text { NO } \\
\text { YES } \\
\text { NO }\end{array}$ & $\begin{array}{l}\text { NO } \\
\text { YES } \\
\text { NO } \\
\text { NO } \\
\text { YES }\end{array}$ \\
\hline
\end{tabular}

To be more conclusive, however, as indicated by equation (57), I revise the specification by adding the interaction of rents, measure of inequality, and the dummy variable for exporta- 
bility.

$$
\begin{aligned}
\text { growth }_{i j t} & =\beta_{0}+\beta_{1} \text { share }_{i j 90}+\beta_{2}\left(\text { exportability }_{i} \cdot \text { rents }_{j t}\right) \\
& +\beta_{3}\left(\text { exportability }_{i} \cdot \text { rents }_{j t} \cdot \text { gini }_{j}\right)+\delta_{i}+\delta_{j}+\delta_{t}+\varepsilon_{i j t}
\end{aligned}
$$

The results in 32 suggest that when I consider not only the resource rents alone, but also how well they are distributed, or put differently, directed to manufacturing industries, I find that a better distribution can help certain industries relative to others. In fact, the significant negative estimated coefficients in column (1) and (2) point out that a higher gini coefficient combined with more rents, can hurt the less homogenous industries in the manufacturing sector and ultimately slow down the growth in this sector. Although, the estimated coefficients on the natural resource rents in the exportable industries of type one seems to not be significant at the conventional levels, they are, however, not very far from that and are significant at 15 percent. Therefore, the threshold effect that was discussed in the chapter 3, seems to be apparent in regard to manufacturing growth as well. This means that for any inequality level higher than a certain value of the gini coefficient, more resource rents will slow down the growth of value added in more sensitive industries to changes in the real exchange rate.

Finally, as presented in table 24, some industries in the manufacturing sector tend to be directly correlated to natural resources which according to my measure of rents includes oil, gas, coal, minerals, and forests. Although, by using industry characteristics and employing the measure of exportability for each industry, I have differentiated between the responsiveness if the industries, in order to check the robustness of the results I generate a restricted sample that excludes the following industries: manufacture of wood and of products of wood and cork, except furniture; manufacture of coke, refined petroleum products and nuclear fuel; manufacture of other non-metallic mineral products; and manufacture of basic metals. 44

The results of estimating equations (56) and (57) with exportability1 using the restricted

\footnotetext{
${ }^{44}$ ISIC codes 20, 23, 26, and 27.
} 
sample are provided in table 33. Although the number of observation have dropped significantly, I can still find a negative effect of the interaction term with the measure of the sensitivity, on the growth of the industries that are less homogenous. Also, there does not exist a highly significant effect of the resource rents alone on the growth of value added in the industries in the restricted sample.

Table 33: Fixed Effects Estimation; Natural Resource Rents and the Distribution (The Restricted Sample)

\begin{tabular}{|c|c|c|c|c|c|c|}
\hline Variables & (1) & (2) & (3) & (4) & (5) & (6) \\
\hline Initial share & $\begin{array}{c}0.039 \\
(0.031)\end{array}$ & $\begin{array}{c}0.038 \\
(0.030)\end{array}$ & $\begin{array}{c}0.039 \\
(0.031)\end{array}$ & $\begin{array}{c}0.041 \\
(0.029)\end{array}$ & $\begin{array}{c}0.040 \\
(0.028)\end{array}$ & $\begin{array}{c}0.041 \\
(0.028)\end{array}$ \\
\hline Natural resource rent $\times$ Exportability 1 & $\begin{array}{l}-0.039 \\
(0.093)\end{array}$ & $\begin{array}{l}-0.051 \\
(0.096)\end{array}$ & $\begin{array}{l}-0.058 \\
(0.112)\end{array}$ & $\begin{array}{c}0.404 \\
(0.244)\end{array}$ & $\begin{array}{c}0.404 \\
(0.252)\end{array}$ & $\begin{array}{r}0.169 \\
(0.249)\end{array}$ \\
\hline $\begin{array}{l}\text { Natural resource rent } \times \text { Gini- } \\
\text { Coefficients } \times \text { Exportability } 1\end{array}$ & & & & $\begin{array}{l}-1.459 * \\
(0.766)\end{array}$ & $\begin{array}{l}-1.462 * \\
(0.777)\end{array}$ & $\begin{array}{l}-0.817 \\
(0.661)\end{array}$ \\
\hline $\begin{array}{l}\text { Observations } \\
\text { R-squared }\end{array}$ & $\begin{array}{l}5,725 \\
0.039\end{array}$ & $\begin{array}{l}5,714 \\
0.087\end{array}$ & $\begin{array}{l}5,725 \\
0.229\end{array}$ & $\begin{array}{l}5,050 \\
0.045\end{array}$ & $\begin{array}{l}5,038 \\
0.096\end{array}$ & $\begin{array}{l}5,050 \\
0.257\end{array}$ \\
\hline $\begin{array}{l}\text { Country FE } \\
\text { Industry FE } \\
\text { Year FE } \\
\text { Industry_year FE } \\
\text { Country_year FE }\end{array}$ & $\begin{array}{l}\text { YES } \\
\text { YES } \\
\text { YES } \\
\text { NO } \\
\text { NO }\end{array}$ & $\begin{array}{l}\text { YES } \\
\text { NO } \\
\text { NO } \\
\text { YES } \\
\text { NO }\end{array}$ & $\begin{array}{l}\text { NO } \\
\text { YES } \\
\text { NO } \\
\text { NO } \\
\text { YES }\end{array}$ & $\begin{array}{l}\text { YES } \\
\text { YES } \\
\text { YES } \\
\text { NO } \\
\text { NO }\end{array}$ & $\begin{array}{l}\text { YES } \\
\text { NO } \\
\text { NO } \\
\text { YES } \\
\text { NO }\end{array}$ & $\begin{array}{l}\text { NO } \\
\text { YES } \\
\text { NO } \\
\text { NO } \\
\text { YES }\end{array}$ \\
\hline
\end{tabular}

Notes: Dependant variable is annual growth rate of manufacturing value added Natural Resource Rents are measured as percentages of GDP. The Gini Coefficient is an index between zero and one. ISIC industry codes 20, 23, 26, and 27 are dropped from the sample. Clustered standard errors are in parentheses. *** Significant at the $1 \%$ level. ** Significant at the $5 \%$ level. * Significant at the $10 \%$ level.

Since the findings in table 33 are very similar to those of columns (1)-(3) in tables 3132 , it is concluded that my results in the original sample are not driven by the apparent direct dependency of some manufacturing industries and it can be generalized and an average effect of the more exportable industries relative to the less exportable industries as defined earlier in this chapter. 


\subsection{Conclusion}

The transfer paradox is an economic problem with a long and distinguished literature. I provide a rather eclectic addition to this paradox and I demonstrate that it has empirical validity. In particular, I show that whereas foreign aid generates a reduction in manufacturing output and growth, remittances have the opposite effect. This distinction is important not only because the literature continually conflates these two types of transfers, but also because remittances are an even larger form of income, than is aid, for developing countries.

I empirically verify these hypotheses with data on the manufacturing value added from a panel of countries and industries covering the years from 1991 to 2009. In the econometric specification I employ the fact that higher relative prices of non-traded to traded good (an appreciation of the real exchange rate) does not affect all industries in the same way. Industries with lower profit margins will suffer more from this exchange rate appreciation. I, therefore, construct two measures of sensitivity for each industry to isolate any additional effect of aid or remittances on industrial growth. Although this sensitivity method should eradicate most of the endogeneity between transfers and growth, I also make use of an instrument for foreign aid and remittances by using characteristics of the donors, and not the recipient countries. The instrument for aid targets the supply of foreign aid by the donors rather than creating an edogeneigty problem by originating form any characteristics of the recipient. Further, in constructing an instrument for remittances I take the origins of the these transfers into account and consider the changes to the supply side as the variation than can tackle possible endogeneigty. To this end, I consider total number of emmigrants in all other countries as an instrument for remittances. I empirically support the hypothesis that remittances generate faster growth in the manufacturing sector and that foreign aid either reduces it or has no significant effect.

Finally, in order to test the results in section 2.5, I apply this method of estimation to resource rents and the distribution to study how the rents distribution affects the growth of manufacturing value added in various industries. My results are very similar to that of chapter 3 in that I find that the less widely distributed resource rents can slow down value 
added growth in certain industries - those more prone to changes in the real exchange rate To make sure that these results are not solely driven by high natural resource dependence of some four industries, I proceed with a robustness check and exclude them from the analysis. The overall results stay unchanged after this alteration in the sample. Additionally, the threshold effect found previously in chapter 3 seems to be at work in this specification as well. 


\section{Bibliography}

[1] Acemoglu, D. and J. Robinson (2012). "Why Nations Fail: The Origins of Power, Prosperity and Poverty". New York: Crown Publishers.

[2] Alesina, A. and B. Weder (2002). "Do corrupt governments receive less foreign aid," American Economic Review, 92 (September), 1126 - 1137.

[3] Arellano, M. and S. Bond (1991). "Some tests of specification for panel data: Monte Carlo evidence and an application to employment equations," Review of Economic Studies, 58, 277-297.

[4] Arellano, M. and O. Bover (1995). "Another look at the instrumental variable estimation of error-components models." Journal of Econometrics, 68, 29-52.

[5] Azam, J. P. and J. J. Laffont (2003). "Contracting For Aid," Journal Of Development Economics, 70(1), 25-58.

[6] Balasko, Y. (1978). "The Transfer Problem and the Theory of Regular Economies," International Economic Review, 19(3), 687-694.

[7] Banerjee, A.V., and E. Duflo (2003). "Inequality and Growth: What can the Data Say?" Journal of Economic Growth, 8, 267-299.

[8] Barro, R. J. (2000). "Inequality and Growth in a Panel of Countries," Journal of Economic Growth, 5(1), 5-32.

[9] Bauer, P. T. (2000). From Subsistence to Exchange. Princeton: Princeton University Press.

[10] Behzadan, N., R, Chisik, H. Onder, and B. Battaile (2016). "Does Inequality Drive the Dutch Disease? Theory and Evidence," Ryerson University Working Paper, Number 44.

[11] Beine, M. , S. Coulombe, and W. Vermeulen (2015). "Dutch Disease and the Mitigation Effect of Migration: Evidence from Canadian Provinces," The Economic Journal, 125(189), 1574-1615.

[12] Blundell, R. and S. Bond. (1998). "Initial conditions and moment restrictions in dynamic panel data models." Journal of Econometrics, 87(1), 115-143.

[13] Blundell, R. and S. Bond. (2000). "GMM estimation with persistent panel data: an application to production functions." Econometric Reviews, 19(3), 321-340.

[14] Bond, S., A. Hoeffler, and J. Temple (2001). "GMM Estimation of Empirical Growth Models," Economics Papers 2001-W21, Economics Group, Nuffield College, University of Oxford.

[15] Brahmbhatt, M., O. Canuto, and E. Vostroknutova (2010). "Dealing with Dutch Disease," World Bank Economic Premise, June 2010, Number 16.

[16] Brunnschweiler, C.N. and E.H. Bulte (2008). "The resource curse revisited and revised: A tale of paradoxes and red herrings," Journal of Environmental Economics and Management, 55(3), $248-264$.

[17] Calfucura, E., A.M. Ortiz, C. Sanborn, and J.L. Dammert (2013). "The Good, The Bad and The Ugly," Americas Quarterly, Winter 2013.

[18] Caron, J., T. Fally and J. R. Markusen (2014). "International Trade Puzzles: A Solution Linking Production And Preferences," Quarterly Journal of Economics, August 2014, Vol. 129(3). 
[19] Chatterjee, S., P. Giuliano, and I. Kaya (2007). "Where Has All The Money Gone? Foreign Aid And The Quest For Growth," Institute For The Study Of Labor (IZA), Bonn, Germany, Discussion Paper No. 2858.

[20] Chichilnisky, G. (1983). "The Transfer Problem with Three Goods once again: Characterization, Uniqueness and Stability," Journal of Development Economics, 13(1-2), 237-247.

[21] Collier, P., F. van der Ploeg, M. Spence, and A.J. Venables (2010). "Managing Resource Revenues in Developing Countries," IMF Staff Papers, 57(1), 84-118.

[22] Collier, P., and B. Goderis (2012). "Commodity prices and growth: An empirical investigation," European Economic Review, 56(6), 1241-1260.

[23] Corden W.M. (1984). "Boom Sector and Dutch Disease Economics: Survey and Consolidation," Oxford Economic Papers, 36(3), 359-380.

[24] Corden W.M. and J.P. Neary (1982). "Booming Sector and De-industrialisation in a Small Open Economy," The Economic Journal, 92 (December), 825-848.

[25] Coyne, C. J. and M. E. Ryan (2009). "With Friends Like These, Who Needs Enemies? Aiding The World's Worst Dictators" The Independent Review, 14 (1), 26 - 44.

[26] Deaton, A. and J. Muellbauer (1980). Economics and Consumer Behavior. Cambridge: Cambridge University Press.

[27] Deininger, K., and L. Squire (1996). "New Data set Measuring Income Inequality," World Bank Economic Review, 10, 565-591.

[28] Depetris C. N. and A. K. Raay (2005). "What Has 100 Billion Dollars Worth Of Debt Relief Done For Low-income Countries," World Bank, Mimeo.

[29] Devarajan, S., A. S. Rajkumar, and V. Swaroop (2007). "What Does Aid To Africa Finance," In Theory And Practice Of Foreign Aid, Ed. By S. Lahiri. Amsterdam: Elsevier.

[30] Diao, X., M. McMillan, and D. Rodrik (2017). "The recent growth boom in developing economies: A structural change perspective," NBER Working Paper, No. 23132.

[31] Dinkelman, T., G. Kumchulesi, and M. Mariotti (2017). "Labor Migration, Capital Accumulation, and the Structure of Rural Labor Markets," Mimeo.

[32] Djankov, S., J. G. Montalvo, and M. Reynal-Querol (2006). "The Curse of Aid," Journal of Economic Growth, 13 (3), September 2008, 1835-1865.

[33] Easterly, W. (2001). The Elusive Quest For Growth: Economists' Adventures And Misadventures In The Tropics. Cambridge: MIT Press.

[34] Easterly, W. (2006). The White Man's Burden: Why The West's Efforts To Aid The Rest Have Done So Much Ill And So Little Good. New York: Penguin.

[35] The Economist (1977). "The Dutch Disease," The Economist, (November 26, 1977), pp. 82-83.

[36] Faini, R., (2007). "Remittances and the Brain Drain: Do More Skilled Migrants Remit More?" The World Bank Economic Review, 21(2), pp. 177-191.

[37] Fajgelbaum, P., G. M. Grossman, and E. Helpman (2011). "Income Distribution, Product Quality, and International Trade," Journal of Political Economy, 119, pp. 721-765. 
[38] Fajgelbaum, P. D. and A. K. Khandelwal (2016). "Measuring the Unequal Gains from Trade, The Quarterly Journal of Economics, 131(3), pp. 1113-1180.

[39] Fieler, A. C. (2011). "Non-homotheticity and Bilateral Trade: Evidence and a Quantitative Explanation," Econometrica, 79, 1069-1101.

[40] Foster, A. D. and M. R. Rosenzweig (2008). "Economic development and the decline of agricultural employment," Handbook of Development Economics, Vol.4: Chapter 47. Elsevier.

[41] Galor, O. and H. M. Polemarchakis (1987). "Intertemporal Equilibrium and The Transfer Paradox", Review of Economic Studies, 54(1), 147-156 .

[42] Gang, I. N. and H. A. Khan (1991). "Foreign Aid, Taxes, And Public Investment," Journal Of Development Economics, 34(1-2), 355-369.

[43] Geanakoplos, J. and G. Heal (1983). "A Geometric Explanation of the Transfer Paradox in a Stable Economy", Journal of Development Economics, 13(1-2), 223-236.

[44] Goderis, B. and S. Malone (2011). "Natural Resource Booms and Inequality: Theory and Evidence," Scandinavian Journal of Economics, 113(2), 388-417.

[45] Gylfason, T. (2001). "Natural Resources, Education, and Economic Development," European Economic Review, 45(4-6), 847-859.

[46] Herrendorf, B., R. Rogerson, and A. Valentinyi (2014). "Growth and structural transformation," in (eds.) Philippe Aghion and Steven N. Durlauf, Handbook of Economic Growth, Volume 2, Elsevier.

[47] Hunter, L. and J.R. Markusen (1988). "Per-capita Income as a Determinant of Trade." In Feenstra, R. (Ed.), Empirical Methods for International Economics. Cambridge: MIT Press, pp. 89-109.

[48] Im, K.S., Pesaran, M.H., and Shin, Y. (2003). "Testing for Unit Roots in heterogeneous Panels." Journal of Economics. 115:53-74

[49] Kapiszewski, A. (2006). "Arab Versus Asian Migrant Workers in the GCC Countries." United Nations Expert Group Meeting on International Migration and Development in the Arab Region, United Nations Secretariat, May 2006.

[50] Keefer, P. and S. Knack (1998). "Polarization, Politics, and Property Rights: Links Between Inequality and Growth," Unpublished manuscript, World Bank.

[51] Keynes, J. M. (1929). "The German Transfer Problem," Economic Journal, 39 pp.1-7.

[52] Khilji, N. M. and E. M. Zampelli (1994): "The Fungibility Of Us Military And Non-military Assistance And The Impacts On Expenditures Of Major Aid Recipients," Journal Of Development Economics, 43(2), 345-362.

[53] Krugman, P. (1987). "The Narrow Moving Band, the Dutch Disease, and the Competitive Consequences of Mrs. Thatcher," Journal of Development Economics, 27(1-2), 41-55.

[54] Leontief, W. (1936). "Note on the Pure Theory of Transfer," in, Explorations in Economics, Taussig Festschrift volume, 84-92, New York.

[55] Markusen, J.R. (2013). "Putting Per-capita Income Back into Trade Theory," Journal of International Economics, 90, 255-265. 
[56] Matsuyama, K. (1992). "Agricultural Productivity, Comparative Advantage, and Economic Growth," Journal of Economic Theory, 58(2), 317-334.

[57] Matsuyama, K. (2000). "A Ricardian Model with a Continuum of Goods under Non- Homothetic Preferences: Demand Complementarities, Income Distribution, and North-South Trade," Journal of Political Economy, 2000, 108, 1093-2000.

[58] McGillivray, M. and O. Morrissey (2000). "Aid Fungibility In Assessing Aid: Red Herring Or True Concern," Journal Of International Development, 12(3), pp. 413-428.

[59] McGillivray, M. and O. Morrissey (2001). "Aid Illusion And Public Sector Fiscal Behaviour," Journal Of Development Studies, 37(6), 118-136.

[60] Mehlum, H., K. Moene, and R. Torvik (2006), "Institutions and the Resource Curse," The Economic Journal, 116, 1-20.

[61] Neary, J.P. (1988). "Determinants of the Equilibrium Real Exchange Rate," American Economic Review, 78(1), 210-215.

[62] Niimi, Y., C. Ozden, and M. Schiff (2010). "Remittances and the Brain Drain: Skilled Migrants Do Remit Less," Annals of Economics and Statistics, 97/98, pp. 123-141.

[63] Ohlin, B. (1929). "The Reparation Problem: A Discussion," Economic Journal, 39 pp.172-178.

[64] OECD (Organisation for Economic Co-operation and Development), Economic Outlook , 2003 Paris OECD

[65] Pack, H. and J. R. Pack (1990). "Is Foreign Aid Fungible? The Case Of Indonesia," Economic Journal, 100(399), 188-194.

[66] Pack, H. and J. R. Pack (1993). "Foreign Aid And The Question Of Fungibility," Review Of Economics And Statistics, 75(2), 258-265.

[67] Piketty, T., (2013). "Capital in the Twenty-First Century," Harvard University Press, Cambridge, MA.

[68] Rajan, R.G. and L. Zingales (1998). "Financial Dependence and Growth," American Economic Review 88(3), 559-86.

[69] Rajan, R. G. and A. Subramanian (2008). "Aid and Growth: What Does the Cross-country Evidence Really Show?" The Review of Economics and Statistics, 90(4), pp. 643-665

[70] Rajan, R. G. and A. Subramanian (2011). "Aid, Dutch Disease, and Manufacturing Growth," Journal of Development Economics, 94, 106-118.

[71] Roodman, D. (2009). "A Note on the Theme of Too Many Instruments," Oxford Bulletin of Economics and Statistics, Department of Economics, University of Oxford, vol. 71(1), pages 135-158, 02.

[72] Rousseau, J.J., (1984). "Discourse on the Origin of Inequality," Penguin Classics, London.

[73] Sachs, J. D., and A. M. Warner (1997a). "Natural Resource Abundance and Economic Growth - Revised Version", Working Paper, Harvard University.

[74] Sachs, J. D., and A. M. Warner (1997b). "Sources of Slow Growth in African Economy", Working Paper, Harvard University. 
[75] Sachs, J. D., and A. M. Warner (2001). "The Curse of Natural Resources," European Economic Review, 45, 827-838.

[76] Samuelson, P. A. (1952). "The Transfer Problem and Transport Costs: The Terms of Trade When Impediments Are Absent," Economic Journal, 62(246), 278-304.

[77] Simonovska, I. (2015). "Income Differences and Prices of Tradables: Insights from an Online Retailer," Review of Economic Studies, 82 (4): 1612-1656.

[78] Stone, J.R.N. (1954). "The Measurement of Consumers' Expenditure and Behaviour in the United Kingdom, 1920-1938, Vol. I." Cambridge: Cambridge University Press.

[79] Swaroop, V., S. Jha, and A. S. Rajkumar (2000). "Fiscal Effects Of Foreign Aid In A Federal System Of Governance: The Case Of India," Journal of Public Economics, 77(3), 307-330.

[80] Temple, J. and N.M. Van de Sijpe (2017). "Foreign Aid and Domestic Absorption," Journal of International Economics, 108, pp. 431-443.

[81] Torvik, R. (2001). "Learning by Doing and the Dutch Disease," European Economic Review, 45(2), 285-306.

[82] United Nations Industrial Development Organization, (2015). Database on Industrial Statistics. Vienna: United Nations.

[83] van der Ploeg, F. and S. Poelhekke (2010). "The Pungent Smell Of Red Herrings: Subsoil Assets, Rents, Volatility And The Resource Curse," Journal of Environmental Economics and Management, 60(1), 44-55.

[84] van der Ploeg, F. (2011). "Natural Resources: Curse or Blessing?" Journal of Economic Literature, 49(2), 366-420.

[85] van der Ploeg, F. and A.J. Venables (2013). "Absorbing a Windfall of Foreign Exchange: Dutch Disease Dynamics," Journal of Development Economics, 103, 229-243.

[86] van Wijnbergen, S. (1985). "Aid, Export promotion and the Real Exchange Rate: an African Dilemma?" Center for Economic Policy Research Paper No. 88.

[87] van Wijnbergen, S. (1986). "Macroeconomic Aspects Of The Effectiveness Of Aid: On The Two-gap Model, Home Goods Disequilibrium, And Real Exchange Rate Misalignment," Journal of International Economics 21 (1-2), 123-136.

[88] World Bank (2013). "World Development Indicators 2013". Washington, DC: World Bank.

[89] World Bank, (2015). "World Development Indicators 2015". Washington, DC: World Bank.

[90] Younas, J. (2008). "Motivation for Bilateral Aid Allocation: Altruism or Trade Benefits," European Journal of Political Economy, 24, 661-674. 